\author{
Universidade de São Paulo \\ FFCLRP - Departamento de Biologia \\ Programa de Pós-Graduação em Biologia Comparada
}

\title{
"Revisão taxonômica dos caranguejos marinhos do gênero Persephona Leach, 1817 (Decapoda, Leucosiidae)"
}

Tatiana Magalhães

Dissertação apresentada à Faculdade de Filosofia, Ciências e Letras de Ribeirão Preto da USP, como parte das exigências para a obtenção do título de Mestre em Ciências, Área: Biologia Comparada.

Ribeirão Preto - SP 


\author{
Universidade de São Paulo \\ FFCLRP - Departamento de Biologia \\ Programa de Pós-Graduação em Biologia Comparada
}

\title{
"Revisão taxonômica dos caranguejos marinhos do gênero Persephona Leach, 1817 (Decapoda, Leucosiidae)"
}

\author{
Tatiana Magalhães \\ Orientador: Fernando Luis Medina Mantelatto \\ Dissertação apresentada à Faculdade de \\ Filosofia, Ciências e Letras de Ribeirão \\ Preto da USP, como parte das \\ exigências para a obtenção do título de \\ Mestre em Ciências, Área: Biologia \\ Comparada.
}

Versão Corrigida

Ribeirão Preto - SP 
Magalhães, Tatiana.

“Revisão taxonômica dos caranguejos marinhos do gênero Persephona Leach, 1817 (Decapoda, Leucosiidae)"/Tatiana Magalhães; orientador: Fernando Luis Medina Mantelatto.

Ribeirão Preto, 2012.

xii + 104p.

Dissertação (Mestrado - Programa de Pós-Graduação em Ciências. Área de concentração: Biologia Comparada) - Faculdade de Filosofia, Ciências e Letras de Ribeirão Preto da Universidade de São Paulo.

1.Brachyura 2. Revisão Taxonômica 3. COI e 16S mtDNA 4. Distância Genética.

5. Análise Filogenética. 
Aos meus pais Carlos e Dalva. 
Agradecimentos 
Ao meu orientador Prof. Dr. Fernando Luis Medina Mantelatto, por todo o ensinamento, empenho em meu crescimento científico e confiança ao longo desses anos no LBSC, além do auxílio imprescindível em várias etapas com obtenção de material biológico e bibliografia de difícil acesso.

À Coordenação de Aperfeiçoamento Pessoal de Nível Superior (CAPES), pela concessão da minha bolsa de mestrado.

Aos projetos que proporcionaram todo o apoio financeiro e logístico, direta ou indiretamente, para o desenvolvimento desta pesquisa junto ao LBSC, concedidos e/ou coordenados do Prof. Dr. Fernando Mantelatto: Fundação de Amparo a Pesquisa do Estado de São Paulo (FAPESP) - Procs. No 1998/07454-5 e 2002/08178-9 (Projetos Individuais de Pesquisa), 2010/50188-8 (Projeto Temático Biota), 2009/54931-0 (Projeto Coleções Científicas); à Coordenação de Aperfeiçoamento de Pessoal de Nível Superior (CAPES) - Proc. No 315/2009 (Projeto Cooperação Internacional); ao Conselho Nacional de Desenvolvimento Científico e Tecnológico (CNPq) - Procs. 472746/2004-9, 471794/2006-6, 473050/2007-2, 471011/2011-8 (Edital Universal, Auxilio Individual a Pesquisa), 491490/2004-6, 490122/2006-0, 490353/2007-0 (Projetos Cooperação Internacional); 301359/2007-5, 302748/2010-5 (Produtividade em Pesquisa).

Ao Departamento de Biologia da Faculdade de Filosofia, Ciências e Letras de Ribeirão Preto da Universidade de São Paulo (FFCLRP/USP), por todo apoio logístico.

À Pró-Reitoria de Pós-Graduação pela concessão do auxílio financeiro para custeio da visita à coleção de crustáceos na University of Louisiana at Lafayette (ULL).

Ao Programa de Pós-graduação em Biologia Comparada (FFCLRP/USP), em especial à ex-coordenadora Profa. Dra. Márcia Maria Gentile Bitondi, pela concessão do auxílio financeiro para o custeio da visita à coleção de crustáceos no National Museum of Natural History (USNM), Smithsonian Institute em Washington, DC.

À todos aqueles que contribuíram com empréstimo, coleta e/ou doação de exemplares de Persephona, esforços sem o qual esse trabalho não poderia ter sido realizado: Prof. Dr. Fernando Mantelatto (USP); Djalma Rosa; Álvaro Costa (USP); Prof. Dr. Rogério Costa (UNESP-Bauru); Prof. Dr. Fernando José Zara (UNESPJaboticabal); Prof. Dr. Antônio Leão Castilho (UNESP-Assis); Prof. Dr. Marcos R. Tavares (MZUSP); Msc. Douglas Peiró (USP); Dra. Mariana R. T. Mariano (USP); Dr. Leonardo A. G. Pileggi (USP); Profa. Dra. Cristiana Serejo (MNRJ); Profa. Dra. Irene Azevedo Cardoso (MNRJ); Dr. Fernando Álvarez Nogueira (CNCR); Prof. Dr. Luiz Ernesto Arruda Bezerra (UFPE); Prof. Dr. Alexandre Oliveira de Almeida (MZUESC); Dr. Darryl L. Felder (ULLZ); Dr. Rafael Lemaitre (USNM); Karen Reed (USNM); Profa. Dra. Paula Beatriz de Araújo (UFRGS); Harry Boos Jr. (CEPSUL); Dr. Rafael Robles; Msc. Nathaniel Evans (UF). 
À Prof. Dra. Maria Helena de Souza Goldman (Laboratório de Biologia Molecular de Plantas, FFCLRP/USP), e em especial à Dra. Andréa Carla Quiapim, pela execução dos passos referentes à precipitação e sequênciamento dos fragmentos moleculares.

Ao Laboratório Multiusuário Centralizado para Sequênciamento de DNA em Larga Escala e Análise de Expressão Gênica da Universidade Estadual Paulista em especial a técnica Agda Facincani pela precipitação e sequênciamento dos fragmentos moleculares.

Ao Prof. Dr. Marcos Domingos Siqueira Tavares (MZUSP), pelas discussões sobre sistemática e taxonomia.

Ao Dr. Darryl L. Felder (ULL) pelas orientações, discussões e sugestões, além do fornecimento de material biológico e bibliográfico referente à Persephona. Agradeço também toda a hospitalidade oferecida no período que estive em Lafayette (LA).

Ao pós-doutorando Rafael Robles pelos ensinamentos, discussões e sugestões sobre análises e técnicas moleculares, "puxões de orelhas", paciência e amizade.

Ao pós-doutorando Leonardo A. G. Pileggi pelos ensinamentos e discussões sobre análises e técnicas moleculares e amizade.

À pós-doutoranda Mariana R. T. Mariano por todo o auxílio, discussões, sugestões, muita paciência e amizade que dispendeu a mim nesses quatro anos no LBSC.

À Dra. Ivana M. Silva por todo ensinamento, discussões com as técnicas moleculares e amizade.

Aos Prof. Dr. Flávio Alicino Bockmann e Prof. Dr. João Atílio Jorge e Pós-doutorando Leonardo A. G. Pileggi, pelas contribuições como membros da banca de qualificação de mestrado.

Ao Dr. Alexandre Oliveira de Almeida pelo auxílio nas dúvidas sobre taxonomia.

Ao Dr. Peter K. L. Ng (National University of Singapure) pelo envio da cópia do trabalho original de Herbst (1794), contendo a descrição e imagem de Persephona mediterranea.

Ao Dr. Michel E. Hendrickx (UNAM) pela discussão sobre P. subovata e I. hancocki.

A Doutoranda Emma Palacios Theil por toda a ajuda despendida a mim enquanto estive na ULL. Além da paciência e amizade. 
À técnica Cláudia Aparecida Rodrigues (Claudinha) do Laboratório de Microscópia Eletrônica e a Técnica Márcia Fioresi Mataqueiro do Laboratório de Citogenética e Morfologia de Invertebrados da FCAV-UNESP, Jaboticabal, pela preparação de material e imagens.

À MSc. Maíra Massarani pela confecção dos desenhos das espécies de Persephona e amizade.

Ao mestrando Mario Bronzati Filho pelas discussões sobre as análises filogenéticas, pelas revisões e pela amizade ao longo desses anos.

À doutoranda Carla Poleselli Bruniera pela revisão, comentários e amizade.

À mestranda Isabela C. Leone pela ajuda na revisão das referências e amizade.

À doutoranda Mariana N. Pereira pelo auxílio com o programa Sequin, para obtenção das sequências do Genbank e amizade.

À doutoranda Raquel C. Buranelli pelas revisões dos textos, sugestões e amizade.

À mestranda Ana Francisca Tamburus Gomes por toda a ajuda e amizade ao longo desses anos no laboratório.

À todos os integrantes e ex-integrantes do LBSC: Ana F. T. Gomes, Andréa L. Meireles, Caio A. M. Pavanelli, Caio de Oliveira, Camila S. Paula, Douglas F. Peiró, Edvanda A. S. Carvalho, Emerson C. Mossolin, Emiliano H. Ocampo, Fabíola C. R. Faria, Fabrício L. Carvalho, Fernanda Gamper Vergamini, Fernanda L. Vasconcelos, Isabela C. Leone, Ivana M. Silva, Jully Iguchi, Leonardo A. G. Pileggi, Lígia M. Amadio, Lucas S. Torati, Lucas L. Zupolini, Mariana N. Pereira; Mariana T. R. Mariano, Marina Z. Fantucci, Nathália M. Santos, Natalia M. Grilli, Natalia Rossi, Nicole A. O. Campilay, Patrício Hernaez Bove, Rafael Robles, Raquel C. Buraneli e Vanessa A. M. Silva, os quais, de alguma maneira, colaboraram para este trabalho, bem como para o meu crescimento como pessoa e pós-graduanda. Agradeço a amizade e agradável convívio diário.

Aos meus amigos Mo e Xitão por toda a ajuda na elaboração final deste trabalho.

Aos meus amigos Carlinha, Giu, Julieto, Mo, Mermão, Rafa, Rosbife, Salsas, Simoni, Tomate, Tocha e Xitão, que de alguma maneira contribuiram para o desenvolvimento deste trabalho.

As minhas flores Giu e Mo por todo apoio, paciência e amizade ao longo desses seis anos. E mesmo com a distância sempre estão presentes na minha vida. Que nossa amizade seja mais que eterna. 
A minha família, em especial aos meus pais Carlos e Dalva e minha irmã Tassi, pelo amor e apoio incondicional dado ao longo da minha jornada. 


\section{SUMÁRIO}

LISTA DE FIGURAS.....................................................................................

LISTA DE TABELAS...................................................................................

LISTA DE ABREVIAÇÕES............................................................................XIII

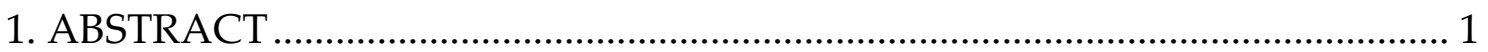

2. RESUMO

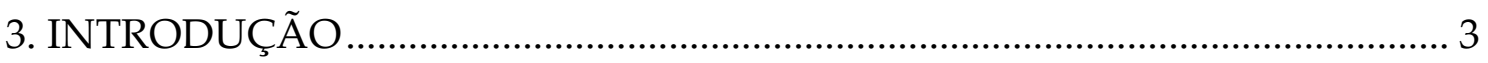

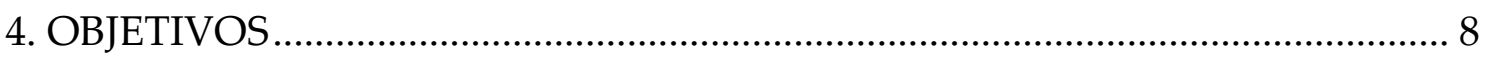

5. MATERIAL \& MÉTODOS.................................................................................. 9

5.1. Obtenção dos dados morfológicos .................................................................. 9

5.2. Obtenção dos dados moleculares.................................................................. 12

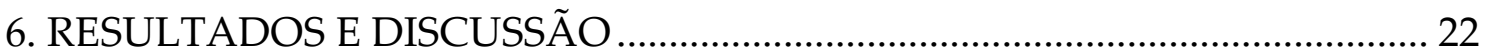

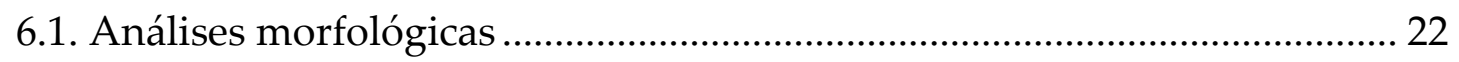

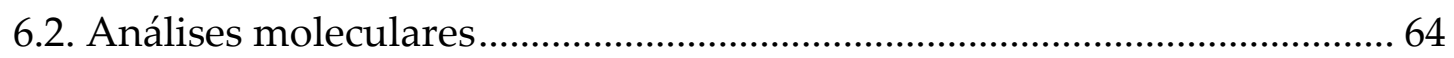

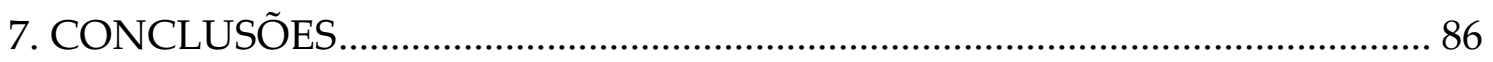

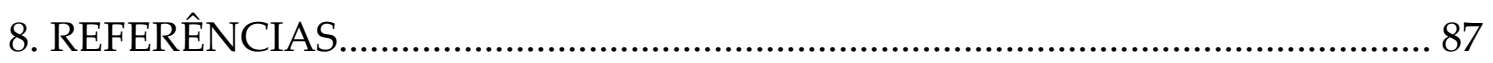




\section{LISTA DE FIGURAS}

FIGURA 1. Desenho esquemático da morfologia externa de um caranguejo da seção Oxystomata, com destaque para as estruturas comumentes utilizadas na identificação de espécies do gênero Persephona (Modificado de Rathbun, 1987).

FIGURA 2. Desenho do mapa com a por países e estados (Brasil e Estados Unidos) dos espécimes de Persephona utilizados nas análises morfológicas, sem considerar a revisão táxonômica.

FIGURA 3. Desenho de um espécime fêmea de $P$. aquilonaris Rathbun, 1933 depositado na ULLZ (9407), em vista dorsal.

FIGURA 4. Desenho de um espécime macho de $P$. crinita Rathbun, 1931 depositado na ULLZ (1847), em vista dorsal. 30

FIGURA 5. Desenho de um espécime macho de P. edwardsii Bell, 1855 depositado na CNCR (18997), em vista dorsal.

FIGURA 6. Imagem de três espécimes de $P$. lichtensteinii, com diferenças no padrão de tamanho dos espinhos em relação ao comprimento da carapaça...... 36

FIGURA 7. Imagem de Microscopia Eletrônica de Varredura (MEV) do gonópodos de espécimes de Persephona crinita do Golfo do México (ULLZ 1847) (A x 35, B x 75 e C x 200) e Persephona lichtensteinii (CCDB 1430) (D x 35, E $\times 75$ e F $\times 200)$.

FIGURA 8. Desenho de um espécime macho de P. lichtensteinii Leach, 1817 depositado na CCDB (1430), em vista dorsal.

FIGURA 9. Ilustração do Cangrejo Tortuga (Parra, 1787), extraído de Parra (1787)

FIGURA 10. Ilustração do Cancer mediterraneus Herbst, 1794, extraído de Herbst (1794)

FIGURA 11. Imagem de um provável exemplar $P$. mediterranea coletado no Sudeste da Flórida (EUA).

FIGURA 12. Microscopia Eletrônica de Varredura (MEV) dos gonópodos de Persephona aquilonaris (ULLZ (ULLZ 9407) (A-35x, B-35x e C-100x) e Persephona mediterranea (CCDB 3881) (D-35x, E-35x e F-200x), setas indicando lobo proeminente no bordo latero-distal. .46 
FIGURA 13. Desenho de um espécime macho de P. mediterranea (Herbst, 1794) depositado na CCDB (3881), em vista dorsal

FIGURA 14. Desenho de um espécime macho de P. orbicularis Bell, 1855 depositado na CCDB (2940), em vista orsal. .50

FIGURA 15. Desenho de um espécime macho de P. punctata (Linnaeus, 1758) depositado na CCDB (1539), em vista dorsal

FIGURA 16. Desenho de um espécime macho de P. subovata (Rathbun, 1894) depositado na CNCR (3269), em vista dorsal.

FIGURA 17. Desenho de um espécime macho de $P$. townsendi (Rathbun, 1894) depositado na CCDB (3025), em vista dorsal

FIGURA 18. Imagem de Microscopia Eletrônica de Varredura (MEV) dos gonópodos das espécies de Persephona: A - P. aquilonaris (aumento de 75x) (ULLZ 9407); B - P. crinita do Golfo do México (aumento de 75x) (ULLZ 1847); C - P. edwardsii (aumento de 75x) (CNCR 18997); D - P. lichtensteinii (aumento de 75x) (CCDB 1430); E - P. mediterranea (aumento de 100x) (CCDB 3881); F - P. orbicularis (aumento de 100x) (CCDB 2940); G - P. punctata (aumento de 100x) (CCDB 1539); H - P. subovata (aumento de 75x) (CNCR 3269); I - P. townsendi (aumento de 75x) (CCDB 3025). .63

FIGURA 19. Gráfico de teste de saturação do gene Citocromo Oxydase I (COI). Gráfico de transição (s) e transvesão (v) versus distância de Tamura e Nei.

FIGURA 20. Mapa com distribuição dos espécimes de Persephona analisados, após revisão taxonômica .72

FIGURA 21. Topologia gerada a partir de análise de Máxima Verossimilhança (MV) para as espécies do gênero Persephona, baseada no gene mitocondrial, citocromo oxidase I (COI), construída no RAxML. Valores dos nós representam o suporte de bootstrap ( $\leq 50 \%$ não apresentados); $1 \mathrm{e}$ 2, agrupamentos monofiléticos. AL: Alagoas; BA: Bahia; ES: Espírito Santo; FL: Flórida; LA: Louisiana; OX: Oaxaca; SC: Santa Catarina; SP: São Paulo; TX: Texas; ATL: A tlântico; PAC: Pacífico.

FIGURA 22. Topologia gerada a partir da análise de Máxima Parcimônia (MP) para as espécies do gênero Persephona, baseada no gene mitocondrial COI, construída no POY. Valores dos nós representam o suporte de Bremer; 1 e 2, agrupamentos monofiléticos. AL: Alagoas; BA: Bahia; ES: Espírito 
Santo; FL: Flórida; LA: Louisiana; SC: Santa Catarina; SP: São Paulo; TX: Texas; ATL: Atlântico; PAC: Pacífico.

FIGURA 23. Topologia gerada a partir da análise de Máxima Verossimilhança (MV) para as espécies do gênero Persephona, baseada no gene mitocondrial, 16S, construída no RAxML. Valores dos nós representam o suporte de bootstrap ( $\leq 50 \%$ não apresentados); 1 e 2, agrupamentos monofiléticos. AL: Alagoas; BA: Bahia; ES: Espírito Santo; FL: Flórida; LA: Louisiana; OX: Oaxaca; SC: Santa Catarina; SP: São Paulo; TX: Texas; ATL: A tlântico; PAC: Pacífico

FIGURA 24. Topologia gerada a partir da análise de Máxima Parcimônia (MP) para as espécies do gênero Persephona, baseada no gene mitocondrial 16S, construída no POY. Valores dos nós representam o suporte de Bremer; 1 e 2, agrupamentos monofiléticos. BA: Bahia; FL: Flórida; LA: Louisiana; SP: São Paulo; TX: Texas; ATL: Atlântico; PAC: Pacífico.

\section{LISTA DE TABELAS}

TABELA I. Lista de caracteres morfológicos utilizados durante a revisão taxonômica dos exemplares do gênero Persephona.

TABELA II. Nome e sequências de primers utilizados na amplificação das sequências alisadas.

TABELA III. Espécimes de caranguejos usados nas análises moleculares com respectiva data e local de coleta, número de catálogo de museu e número de acesso do banco de dados genético (Genbank). (CCDB - Coleção de Crustáceos do Departamento de Biologia, FFCLRP, Universidade de São Paulo; CNCR - Colección Nacional de Crustáceos, Instituto de Biología, UNAM; MZUSP - Museu de Zoologia da Universidade de São Paulo; UFUniversity of Florida; ULLZ - University of Louisiana at Lafayette's Zoology Collection; USNM - United States Museum National Smithsonian, Museum Natural of Natural History, Washington DC/USA). BRA - Brasil; COL - Colômbia; CRI - Costa Rica; EUA - Estados Unidos; HON - Honduras; MAR - Marrocos; MEX - México; PAN - Panamá; VNZ - Venezuela. .18

TABELA IV. Matriz de divergência genética da subunidade do gene COI entre as espécies de Persephona; AL: Alagoas; BA: Bahia; ES: Espírito Santo; FL: Flórida; LA: Louisiana; OX: Oaxaca; SC: Santa Catarina; SP: São Paulo; TX: Texas; ATL: Atlântico; PAC: Pacífico. .69 
TABELA V. Matriz de divergência genética da subunidade do gene $16 \mathrm{~S}$ entre as espécies de Persephona; BA: Bahia; FL: Flórida; LA: Louisiana; SP: São Paulo; TX: Texas; ATL: Atlântico; PAC: Pacífico. .71

\section{LISTA DE ABREVIATURAS}

CCDB- Coleção de Crustáceos do Departamento de Biologia;

LBSC- Laboratório de Bioecologia e Sistemática de Crustáceos;

CNCR- Colección Nacional de Crustáceo;

UNAM- Universidad Autónoma de México;

MNRJ- Museu Nacional da Universidade Federal do Rio de;

MZUSP- Museu de Zoologia da USP;

MZUESC- Museu de Zoologia da Universidade Estadual de Santa;

USNM- United States Museum National;

UFPE- Universidade Federal do Pernambuco;

UF- University of Florida;

ULLZ- University of Louisiana-Lafayette;

MEV- Microscopia Eletrônica de Varredura;

CC- Comprimento da Carapaça;

MV- Máxima Verossimilhança;

MP- Máxima Parcimônia;

pl. - plate;

pr.- prancha;

fig.- figura;

s/n- sem número; 


\section{Abstract}


The genus Persephona Leach, 1817 is restricted to America and consists of ten species occurring in the Western Atlantic and Eastern Pacific. It belongs to the subfamily Ebaliinae, which is not taxonomically well established. Over the years, Persephona was placed in different subfamilies and its classification is still poorly defined. Also, existing identification keys do not allow a correct classification of the species within the genus. These informations are indicatives of a strong need of studies focusing on Persephona, which can provide a better understanding concerning its evolutionary history. in this context, the present study intends to undertake a broad taxonomic revision of the genus Persephona, including characters possessing great variability within the genus (number and size of the spines, cheliped, etc.), characters traditionally used in the diagnosis of the species, and others selected from the present study (gonopod, coloration, etc.), including for the first time for the genus, analyses of molecular data. As guides for the molecular analyses, two mitochondrial genes, the 16S rRNA and the Cytochrome Oxidase I (COI) were used as markers. The morphological analyses revealed an absence of differences among some species proposed for the genus Persephona, wich were corroborated by molecular and phylogenetic analysis. In this way, is propose modifications regarding Persephona taxonomy: $P$. finneganae is a junior synonym of $P$. lichtensteinii: the name $P$. crinita is valid only for specimens occurring in the Gulf of Mexico; the specimens of $P$. mediterranea with occurence in the Gulf of Mexico, correspond to P. aquilonaris and those with occurence in the Caribbean and South Atlantic correspond to $P$. mediterranea, moreover I. hancocki is a junior synonym of P. subovata.

Key words: 1. Brachyura 2. Taxonomic Review 3. COI and 16S mtDNA

4. Distance Genetic 5. Phylogenetic Analysis. 
O gênero Persephona Leach, 1817 é restrito a América e é constituído por dez espécies com ocorrência no Atlântico Ocidental e Pacífico Oriental, estando inserido na subfamília Ebaliinae, a qual não se encontra taxonomicamente bem estabelecida. Ao longo dos anos, este gênero foi alocado em diferentes subfamílias e sua classificação é mal definida. Além disso, existem chaves de identificação que não permitem a correta identificação das espécies dentro do gênero. Estas infomações são indicativos de uma forte necessidade de estudos enfocando Persephona, os quais podem fornecer uma melhor compreensão sobre a história evolutiva do gênero. Neste contexto, o presente estudo pretendeu realizar uma ampla revisão taxonômica do gênero Persephona, incluindo caracteres que possuem grande variabilidade dentro do gênero (número e tamanho dos espinhos, quelípodos, etc), caracteres tradicionalmente utilizados na diagnose das espécies, além de outros selecionados a partir do presente estudo (gonópodos, coloração, etc), além de incluir pela primeira vez para o gênero, análises de dados moleculares. Dois genes mitocondriais, o 16S rRNA e o Citocromo Oxidase I (COI) foram utilizados como marcadores. As análises morfológicas revelaram uma ausência de diferenças entre algumas espécies propostas para o gênero Persephona, as quais foram corroboradas pelas análises moleculares. Desta forma, são propostas modificações a respeito da taxonomia de Persephona: $P$. finneganae é um sinônimo júnior de $P$. lichtensteinii. O nome $P$. crinita é valido apenas para os espécimes de ocorrência no Golfo do México; os espécimes de $P$. mediterranea com ocorrência no Golfo do México, correspondem a $P$. aquilonaris e aqueles com ocorrência no Caribe e Atlântico Sul, correspondem a $P$. mediterranea e além do exposto, Iliacantha hancocki é um sinônimo júnior de P. subovata.

Palavras-Chaves: 1. Brachyura 2. Revisão Taxonômica 3. COI e 16S

4. Distância Genética 5. Análise Filogenética. 


\section{Introdução}


Dentre os Crustacea (Pennant, 1777), o grupo mais intensamente estudado tem sido os caranguejos verdadeiros da infraordem Brachyura (Latreille, 1803). Os braquiúros pertencentes à ordem Decapoda (Latreille, 1803), são os representantes viventes mais diversos, com inúmeras espécies distintas. O sucesso evolutivo pode ser relacionado ao padrão de colonização desses animais, que habitam ambientes terrestres, de 2.000 metros acima do nível do mar até zonas abissais abaixo de 6.000 metros de profundidade. Atualmente, os Decapoda contém estimadamente 15.000 espécies, algumas das quais de grande importância alimentar e industrial, com grande relevância na economia mundial (Ng et al., 2008; Martin et al., 2009; Toon et al., 2009).

A grande diversidade de crustáceos decápodos existentes atualmente, juntamente com a grande importância comercial de alguns, têm levado ao aumento do número de pesquisas a respeito desses animais, incluindo estudos sobre as relações filogenéticas. Essas análises têm sido amplamente realizadas, seja por meio de análise de dados larvais, dados morfológicos, dados comportamentais e, recentemente, moleculares. A sistemática molecular tem sido utilizada com sucesso, com o objetivo de elucidar problemas taxonômicos em decápodes (Murphy \& Austin, 2003; Mantelatto et al., 2009a; Pileggi \& Mantelatto, 2010). No entanto, é possível observar que as relações entre vários grupos ainda não são consensuais (Martin et al., 2009). Além disso, existem diversos problemas quanto à identificação e classificação desses animais e esses problemas taxonômicos ocorrem normalmente por falta de trabalhos para animais de uma determinada região, chaves de identificação mal elaboradas, ou preservações mal feitas dos espécimes.

Incluída nesse panorama de classificação e relações não bem estabelecidas entre os Decapoda, encontra-se a família Leucosiidae, descrita originalmente por Samouelle (1819) com a espécie Ebalia pennantii (Nobre, 1936). É representada pelos braquiúros comumente chamados de "purse crabs", 
os quais apresentam as aberturas dos canais branquiais em cada lado do endostômio. Este é coberto pelos exognatos do terceiro maxilípodo, fechando completamente o quadro bucal, exceto por uma pequena abertura frontal. Além disso, apresentam palpo articulado atrás do meropodito do terceiro maxilípodo (Rathbun, 1937; Williams, 1984; Torres, 1998). São comumente encontrados em fundo de areia, cascalhos e lama, desde a costa até cerca de 400m de profundidade (Melo, 1996). Segundo Torres (1998), Leucosiidae é representada no Brasil por 21 espécies agrupadas em nove gêneros (Callidactylus Stimpson, 1871, Ebalia Leach, 1817, Iliacantaha Stimpson, 1871, Lithadia Bell, 1855, Myropsis Stimpson, 1871, Persephona Leach, 1817, Randallia Stimpson, 1857, Spelophoroides Melo \& Torres, 1998 e Speloeophorus A. Milne-Edwards, 1865) e três subfamílias (Ebaliinae Stimpson, 1871, Iliinae Stimpson, 1871 e Leucosiinae Samouelle, 1919).

De acordo com a revisão mais recente sobre os Brachyura ( $\mathrm{Ng}$ et al., 2008), este táxon, com um total de 63 gêneros e 464 espécies, pode ser dividido em quatro ou cinco subfamílias, Leucosiinae, Cryptocneminae Stimpson, 1907 e Ebaliinae, Philyrinae (Rathbun, 1937) e talvez Illinae, sendo amplamente distribuídas em águas marinhas.

Analisando o histórico dos estudos acerca da sistemática da família Leucosiidae, é possível observar que este grupo tem sofrido diversas mudanças que ainda resultam em incertezas quanto a sua classificação. Glaessner (1969) observou que alguns autores dividiram a família Leucosiidae em subfamílias com definições e composições distintas, o que causa confusão até hoje quanto ao posicionamento de gêneros e espécies dentro desta família. (ver Manning \& Holthuis, 1981 para revisão).

De acordo com $\mathrm{Ng}$ et al. (2008), dentre as cinco subfamílias válidas atualmente, Ebaliinae, juntamente com Philyrinae e Iliinae, não estão bem estabelecidas, uma vez que os caracteres diagnósticos utilizados por Rathbun 
(1937), Sakai (1976) e Chen \& Sun (2002) não são convincentes e a alocação dos gêneros nas diferentes subfamílias tem sido bastante subjetiva. Hendrickx (1997), em seu trabalho sobre os braquiúros do Pacífico Mexicano, também avaliou que Leucosiidae tem sido dividida de maneira variável, em subfamílias que nem sempre são bem definidas; da mesma maneira, Manning \& Holthuis (1981), em uma ampla revisão taxonômica dentro de Leucosiidae, afirmaram 31 anos antes sobre a necessidade de um estudo comparativo em nível de gênero para esta família.

Dentro da família Leucosiidae encontra-se o gênero Persephona Leach, 1817, que está inserido na subfamília Ebaliinae, sendo constituído atualmente por 10 espécies nominalmente reconhecidas ( $\mathrm{Ng}$ et al., 2008): Persephona aquilonaris Rathbun, 1933, P. crinita Rathbun 1931, P. finneganae Rathbun 1933, P. lichtensteinii Leach 1817, P. mediterranea (Herbst, 1794), P. punctata (Linnaeus, 1758) no Atlântico Ocidental e P. edwardsii Bell 1855, P. orbicularis Bell 1855, P. subovata (Rathbun, 1893) e P. townsendi (Rathbun, 1893) no Pacífico Oriental (Rathbun, 1937; Garth, 1946; Buitendijk, 1950; Stimpson, 1859; Garth, 1966; Del Solar, 1970; Melo, 1996; Spivak, 1997; Torres, 1998; Wehrtmann \& EcheverríaSáenz, 2007; Varga-Castillo, 2008).

A espécie tipo do gênero foi descrita originalmente como Persephona latreillei Leach, 1817 e, após revisão, o gênero Guaia H. Milne Edwards, 1837, descrito com base na espécie tipo Cancer punctatus Linnaeus, 1758 foi sinonimizado a Persephona, e as espécies C. punctatus e P. latreillei sinonimizadas a P. punctata (Linnaeus, 1758), tornando-se a espécie tipo do gênero ( $\mathrm{Ng}$ et al., 2008).

De acordo com Rathbun (1937), os indivíduos pertencentes ao gênero Persephona são definidos por apresentarem uma carapaça ovóide ou globular, terminando posteriormente em três espinhos; dois nas bordas e um mediano superior; superfície lisa ou granular e regiões não totalmente demarcadas. 
Fronte bem delimitada do restante da carapaça. Prolongamentos dentiformes dos septos dos canais branquiais projetam-se à frente. Parede lateral da região hepática, que comumente faz uma faceta distinta, é geralmente separada da região branquial por uma ampla incisura na margem anterolateral. Órbitas profundas, ocultando os olhos retraídos. Assoalho da carapaça coincide com o teto na cavidade bucal. Antenas frouxamente fixadas no fundo do canto interno da órbita. Antênulas dobradas obliquamente. Cavidade bucal alongada. Mero do terceiro maxilípodo triangular, metade ou um pouco maior que metade do comprimento do ísquio mensurado no lado interno; segundo artículo da exognato com margem externa mais ou menos curvada. Quelípodos são maciços, abdomens dos machos possuem os segmentos 3-5 fusionados, e as fêmeas segmentos 4-6 fusionados.

O gênero Persephona, assim como a família Leucosiidae, também apresenta problemas quanto a sua sistemática. Ao longo dos anos, este gênero foi alocado em diferentes subfamílias, como, por exemplo, em Iliinae (Rathbun, 1937; Williams, 1984) e Ebaliinae (Melo, 1996).

Segundo Hendrickx (1997), a classificação específica de Persephona e de Iliacantha Stimpson, 1871 são exemplos de classificações incertas, já que ambas encontram-se mal definidas, além de algumas chaves de identificação (Rathbun, 1937; Williams, 1984) que não permitem a separação entre as espécies, sendo, portanto, necessária análise do material tipo, quando disponível, com a finalidade de se garantir uma correta identificação. Outro exemplo a ser citado sobre os problemas no gênero inclui a descrição de duas espécies do gênero Myra Leach, 1817, M. townsendi Rathbun, 1893 e M. subovata Rathbun, 1893 do Golfo da Califórnia. Rathbun notou que estas eram muito parecidas com espécies de Persephona e em 1902 sugeriu que o gênero Myra não era distinto de Persephona, sinonimizando Myra a Persephona. Posteriormente em 1937, a autora se retratou e validou o gênero Myra (Galil, 2001). 
Especificamente a validade taxonômica de algumas espécies é questionada por alguns autores (Holthuis, 1959; Torres, 1998), tais como $P$. crinita e P. finneganae, ambas morfologicamente muito similares a $P$. lichtensteinii. Rathbun (1937), em sua chave de identificação para essas espécies afirmou que $P$. crinita apresenta nove excrescências curtas, tuberculiformes, enquanto $P$. finneganae apresenta sete espinhos e dois tubérculos e $P$. lichtensteinii, sete espinhos. No entanto, Holthuis (1959) observou que o caráter, presença de tubérculo entre os espinhos laterais e subhepáticos, utilizado para separar $P$. finneganae e $P$. lichtensteinii é variável, além da variação de tamanho e da largura dos espinhos, sugerindo que $P$. finneganae deveria ser sinonimizada a P. lichtensteinii. Torres (1998), analisando espécies da família no Brasil, apresentou a mesma opinião, mas sugerindo que $P$. finneganae e $P$. crinita do Brasil são sinônimas de P. lichtensteinii. Entretanto seu trabalho foi publicado apenas em formato de tese, sem ampla divugação científica, sendo as três espécies ainda consideradas válidas por muitos autores, incluindo a mais recente revisão dos braquiúros, o Systema Brachyurorum de $\mathrm{Ng}$ et al. (2008).

Apesar da controversa sistemática da família Leucosiidae e do gênero Persephona, a escassez de trabalhos sobre revisão taxonômica, específicos para este gênero ainda persiste, indicando a necessidade de estudos que elucidem as relações filogenéticas entre as espécies que o compõem. A taxonomia atual das espécies de Persephona tem sido baseada na morfologia de adultos, o que algumas vezes não permite correta separação, devido a grande similaridade morfológica somática das espécies. Diante deste cenário, um estudo taxonômico e sistemático envolvendo o gênero, incluindo uma ampla análise de caracteres morfológicos e moleculares, utilizando-se de metodologias variadas, torna-se fundamental para elucidar as relações filogenéticas entre as espécies que compõem o gênero Persephona e consequentemente da família Leucosiidae. 


\section{Objetivos}


Baseado no cenário relatado anteriormente, que demonstra um acúmulo de incertezas e um precário conhecimento sobre a sistemática dos caranguejos pertencentes a este grupo, o presente estudo teve como objetivos:

- Realizar uma revisão taxonômica das espécies do gênero Persephona distribuídas no Atlântico Ocidental;

- Avaliar as hipóteses postuladas para a proposição de sinonímias entre algumas das espécies do gênero, utilizando análise de cluster, baseada nas distâncias genéticas entre as sequências nucleotídicas dos genes 16S e COI;

- Estudar as relações filogenéticas das espécies do gênero Persephona, utilizando genes mitocondriais $16 \mathrm{~S}$ e COI; 


\section{Material \& Métodos}




\subsection{Obtenção dos dados morfológicos}

Os espécimes utilizados nas análises foram obtidos por meio de novas coletas, empréstimo, doações e visitas in loco as coleções carcinológicas de instituições científicas. As coletas foram realizadas por meio de barcos de pesca equipados com redes de arrasto de fundo. Os animais coletados e doados foram devidamente identificados, etiquetados, armazenados em frasco com álcool etílico $80 \%$ e depositados na Coleção de Crustáceos do Departamento de Biologia (CCDB) do Laboratório de Bioecologia e Sistemática de Crustáceos (LBSC), Faculdade de Filosofia, Ciências e Letras de Ribeirão Preto, Universidade de São Paulo (FFCLRP/USP), Ribeirão Preto, São Paulo/Brasil. Alguns animais ou sequências foram obtidos a partir de outras coleções: Colección Nacional de Crustáceos (CNCR), Instituto de Biología, Universidad Autónoma de México, (UNAM), Ciudad de Mexico/México; Museu Nacional da Universidade Federal do Rio de Janeiro (MNRJ), Rio de Janeiro, RJ/Brasil; Museu de Zoologia da USP (MZUSP) São Paulo, SP/Brasil; Museu de Zoologia da Universidade Estadual de Santa Cruz (MZUESC), Ilhéus, BA/Brasil; United States Museum National (USNM) Smithsonian Institution, Museum National of Natural History, Washington DC/USA; Universidade Federal do Pernambuco (UFPE) Recife, PE/Brasil; University of Florida (UF), Gainesville, FL/EUA; University of Louisiana-Lafayette, Zoological Collections (ULLZ) Lafayette, LA/EUA.

Foram realizadas visitas às coleções do MNRJ, MZUSP, USNM e ULLZ, permitindo a análise de espécimes do gênero e da família, incluindo material tipo das espécies de $P$. punctata aquilonaris, $P$. finneganae, $P$. subovata, $P$. townsendi, além do parátipo de $P$. finneganae e síntipos de $P$. crinita.

A identificação das espécies foi confirmada com base em caracteres morfológicos de Herbst (1794), Leach (1817), Bell (1855), Rathbun (1893, 1931, 1937), Williams (1984), Melo (1996) e Torres (1998), que juntamente com os 
demais caracteres levantados durante as análises, foram reunidos e listados (Tab. I), auxiliando nas análises morfológicas.

Tabela I - Lista de caracteres morfológicos utilizados durante a revisão taxonômica dos exemplares do gênero Persephona.

\section{Caracteres Morfológicos}

Carapaça: comprimento, largura; presença e disposição de cerdas, grânulos e espinhos;

Terceiro maxilípodo: presença e disposição de cerdas e grânulos;

Quelípodo: forma e tamanho; proporção dos artículos; fórmula de dentes dos dedos da quela e presença de cerdas;

Fronte: formato e presença e cerdas;

Espinhos da margem posterior: comprimento e posição; presença de cerdas;

Patas ambulatórias: proporção dos artículos; presença de fileiras de cerdas;

Abdomen: disposição de cerdas e grânulos;

Espinhos ou grânulos: número e formato;

Gonópodo: formato e tamanho; presença e ausência de ornamentação; presença de cerda;

Foram analisados, quando possível, exemplares adultos de machos, fêmeas ovígeras e não ovígeras e também juvenis de diferentes localidades do Atlântico Ocidental e Pacífico Oriental. Posteriormente, foi realizada uma análise comparativa dos caracteres, identificando aqueles de maior variação entre as espécies e utilizados na diagnose das mesmas (Fig. 1). Além da análise comparativa, foi elaborada uma coletânea taxonômica e sistemática das espécies de Persephona a partir da literatura, juntamente com os dados obtidos nesse estudo.

As análises morfológicas realizadas no LBSC-FFCLRP/USP foram feitas sob estereomicroscópio MZ6 LEICA ${ }^{\circledR}$. Os exemplares foram mensurados com paquímetro digital STARRETT ${ }^{\circledR} 727(0,01 \mathrm{~mm})$. 

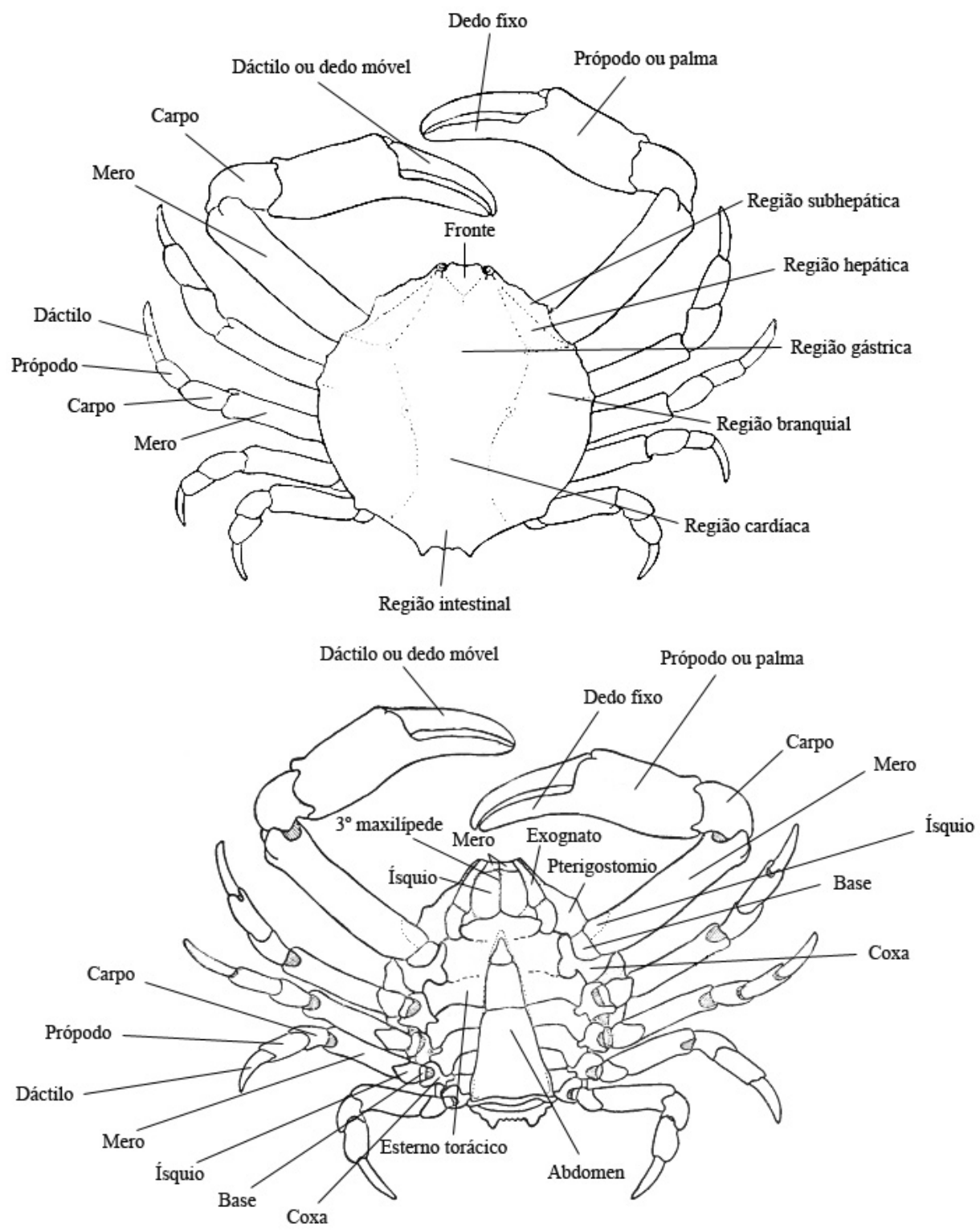

Figura 1. Esquema da vista dorsal (superior) e ventral (inferior) de um caranguejo Oxystomata, modificado de Rathbun (1937).

Para a análise morfológica dos gonópodos, estes foram dissecados e fixados em glutaraldeído 3\%. Posteriormente as amostras foram desidratadas em banhos de álcool de 30, 50, 70, 80, 90 e 100\%, por 30 minutos cada, sendo o último banho de $100 \%$ repetido três vezes. Após essa etapa, as amostras foram submetidas à secagem em ponto crítico com CO2 líquido no EMS 850 (Electron Microscopy Sciences ${ }^{\circledR}$ ), montadas em strubs e recobertas por uma fina camada de ouro 24k em um metalizador Denton Vacuum Desk II. As fotografias foram 
tiradas com microscópio eletrônico de varredura (MEV) JSM 5410 (JOEL ${ }^{\circledR}$ ) no Laboratório de Microscopia Eletrônica da Faculdade de Ciências Agrárias e Veterinária, UNESP, Jaboticabal. As micrografias eletrônicas obtidas foram digitalizadas e editadas no programa de edição de imagens Adobe Photoshop CS3 (Adobe System ${ }^{\circledR}$ ).

\subsection{Obtenção dos dados moleculares}

As divergências genéticas foram baseadas em genes mitocondriais, considerados importantes marcadores moleculares utilizados em estudos de biologia evolutiva e populacional. Genes mitocondriais apresentam organização simples, herança materna e ausência de recombinação, o que permitem fácil isolamento e comparação de sequências homólogas (Harrison, 1989). Com a alta taxa de variação de alguns marcadores, é permitido o acesso à estrutura populacional, além de contribuir com variação geográfica, zoogeografia e filogenias (Harrison, 1989). Foi utilizado um fragmento parcial de $16 \mathrm{~S}$ rRNA (16S), um gene com regiões conservativas e taxa de evolução lenta, amplamente utilizado em reconstruções filogenéticas e verificação de status taxonômicos (Schubart et al., 2000; Mantelatto et al., 2010), e um fragmento parcial do gene citocromo oxidase subunidade I (COI), que possui taxas de evolução rápida, permitindo acesso a estrutura populacional (Moritz et al., 1987; Vergamini, 2009). Ambos os genes tem sido amplamente utilizados em análises moleculares de crustáceos decápodes (Schubart et al., 2000; Pileggi \& Mantelatto, 2010; Vergamini et al., 2011; Terossi \& Mantelatto, in press).

\section{Extração de DNA}

O DNA genômico foi extraído do tecido muscular dos quelípodos. Os procedimentos seguiram Mantelatto et al. (2009b), Pileggi \& Mantelatto (2010) e Vergamini et al. (2011), com modificações apropriadas ao tipo de material. Os 
tecidos foram incubados por $48 \mathrm{~h}$ em tampão de lise $\left(\mathrm{H}_{2} \mathrm{O}\right.$ Milli-Q Autoclavada,

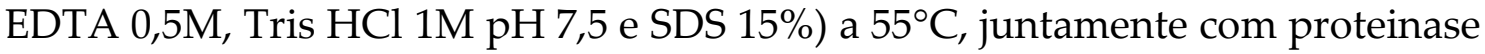

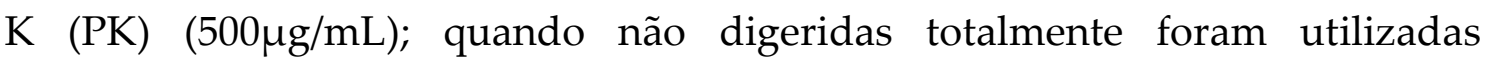
ponteiras de maceração, voltando-se a amostra para o banho seco por mais $2 \mathrm{~h}$. Os eppenorfs foram colocados em gelo por 10min para a inativação da PK. As proteínas foram separadas pela adição de acetato de amônio 7,5M e a amostra centrifugada a $14.000 \mathrm{rpm}$ por $10 \mathrm{~min}$. Transferiu-se todo o sobrenadante da amostra para outro eppendorf com isopropanol gelado, o qual é responsável pela precipitação do DNA, e a amostra foi centrifugada a $14.000 \mathrm{rpm}$ por $10 \mathrm{~min}$. A amostra foi deixada no freezer por 24h. Posteriormente, a amostra foi centrifugada a $14.000 \mathrm{rpm}$ por $10 \mathrm{~min}$ e o sobrenadante foi descartado. O pellet resultante foi lavado com etanol $70 \%$ e a amostra colocada na geladeira por 10min. A amostra foi centrifugada a $14.000 \mathrm{rpm}$ por $10 \mathrm{~min}$ e o sobrenadante descartado. Em seguida o pellet foi liofilizado a $30^{\circ} \mathrm{C}$ por aproximadamente 15min e ressuspendido em tampão TE 1x (Água destilada autoclavasa, TrisHcl $1 \mathrm{M}$ e EDTA $0,5 \mathrm{M}$. A amostra foi incubada em banho seco por $15 \mathrm{~min}$ a $65^{\circ} \mathrm{C}$ e posteriormente armazenada em freezer.

Por meio da observação de eletroforese em gel de agarose 1\% (1g de agarose $+100 \mathrm{~mL}$ de tampão TBE $1 \mathrm{x}$ ), foi possível verificar a concentração do DNA extraído, adicionando em cada poço uma mistura de amostra da extração, Gel Red (10.000x Biotium), loading, além de um marcador (High Ranger 1kb DNA da Norgen), em uma corrida de aproximadamente 40min. Os resultados foram fotografados com câmera digital C-7070 da Olimpus ${ }^{\circledR}$ em um transiluminador UV Transilluminator M20 da UVP ${ }^{\circledR}$ e analisadas as espessuras das bandas. Quando disponível, em algumas amostras, foi utilizado espectrofotômetro (NanoDrop 1000 Spectrophotometer) para medir a concentração total da amostra, a partir da adição de $\mathrm{H}_{2} \mathrm{O}$ deionizada para a 
leitura em branco, minimizando os erros causados pela absorção de luz pela água e posterior adição de cada amostra.

Amplificação do DNA

A amplificação de aproximadamente 485pb do gene 16S rDNA (Schubart \& Huber, 2006) e 606pb do gene Citocromo Oxidase subunidade I, (Folmer et al., 1994; Schubart \& Huber, 2006), foi realizada pela reação de PCR (Polymerase Chain Reaction), nos termocicladores $A B$ da Applied Biosystem ${ }^{\circledR}$ e no PxE 0.2 Thermal Cycler da Thermo ${ }^{\circledR}$, utilizando iniciadores (primers) universais (Tab. II).

Tabela II. Primers utilizados na amplificação das sequências analisadas.

\begin{tabular}{c|c}
\hline Primer & Sequência \\
\hline 16SH9* & 5'-CCGGTCTGAACTCAGATCAC-3' \\
16SL9* & 5'-CGCCTGTTTATCAAAAACAT-3' \\
COICOH6* & 5'-TADACTTCDGGRTGDCCAAARAAYCA-3' \\
COICOL6b ${ }^{*}$ & 5'-ACAAAATCATAAAGATATYGG-3' \\
COIHCOI1 & 5'-TAAACTTCAGGGTGACCAAAAAATCA-3' \\
COILCO1 $^{* *}$ & 5'-GGTCAACAAATCATAAAGATATTG-3' \\
\hline
\end{tabular}

*Schubart \& Huber, 2006; ${ }^{* *}$ Folmer et al., 1994

Cada produto de PCR foi obtido para uma reação de $25 \mu \mathrm{L}$ totais utilizando $\mathrm{H}_{2} \mathrm{O}$ destilada e deionizada, Betaína 5M, DNTPs $10 \mathrm{mM}$, Taq buffer 10x $\mathrm{MgCl}_{2} 25 \mathrm{mM}$, primers (16S $10 \mu \mathrm{M}$ e COI 20 $\mu \mathrm{M}$ ), Thermus aquaticus (Taq polimerase-Fermentas) (5 U/ $\mu \mathrm{l})$ e volume de DNA previamente calculado. Os ciclos termais foram adequados para cada primer. Para os primers $16 \mathrm{SH} 9$ e 16SL9 a desnaturação inicial foi de 5 minutos a $95^{\circ} \mathrm{C}$; anelamento por 40 ciclos $\left(45 \mathrm{~s}\right.$ a $95^{\circ} \mathrm{C}$; $30 \mathrm{~s}$ a $44-50^{\circ} \mathrm{C}$ e $1 \mathrm{~min}$ a $\left.72^{\circ} \mathrm{C}\right)$; extensão final por $5 \mathrm{~min}$ a $72^{\circ} \mathrm{C}$; Para os primers COICOH6, COICOL6b, COIHCOI1 e COILCOI1 a desnaturação inicial foi de 5 minutos a $94^{\circ} \mathrm{C}$; anelamento por 35 ciclos $\left(45\right.$ s a $94^{\circ} \mathrm{C}$; 30s a $42-$ 
$48^{\circ} \mathrm{C}$ e $1 \mathrm{~min}$ a $72^{\circ} \mathrm{C}$ ); extensão final por $5 \mathrm{~min}$ a $72^{\circ} \mathrm{C}$; Os resultados obtidos foram observados em eletroforese com gel de agarose $1 \%$ e fotografados com câmara digital C-7070 Olimpus ${ }^{\circledR}$ em um transluminator UV M20 UVP ${ }^{\circledR}$.

Purificação e amplificação do produto do PCR

A purificação dos produtos de PCR foi feita por meio do kit SureClean Plus $^{\circledR}$. Foram adicionados ao produto de PCR $6 \mu \mathrm{L}$ de corante co-precipitante pink e homogeneizada a mistura. Em seguida foi adicionado o volume de SureClean igual ao volume do produto de PCR, homogeneizado e imcubado a temperatura ambiente por $10 \mathrm{~min}$. A amostra foi centrifugada por $15 \mathrm{~min}$, a $14.000 \mathrm{~g}$ e em seguida o sobrenadante foi descartado. Foi adicionado etanol $70 \%$, duas vezes o volume da amostra e homogeneizada a mistura no vórtex. A amostra foi centrifugadao por $15 \mathrm{~min}$, a $14.000 \mathrm{~g}$ e o sobrenadante descartado. Em seguida a amostra foi liofilizada a $30^{\circ} \mathrm{C}$ por aproximadamente $2 \mathrm{~min}$, posteriormente ressuspendida em tampão TE 1x e armazeada em freezer.

A reação de PCR de sequênciamento foi realizada para um volume total de $20 \mu \mathrm{L}$ contendo $\mathrm{H}_{2} \mathrm{O}$ destilada e deionizada (quantidade necesária para completar o volume total, Big Dye ${ }^{\circledR}$ Terminator Sequencing Buffer (2,5x), Big Dye ${ }^{\circledR}$ Terminator Cycle Sequencing (Applied Biosystems), primer (10-20 $\left.\mu \mathrm{M}\right)$ e produto do PCR previamente purificado. O PCR de sequênciamento foi realizado com o ciclo termal: desnaturação inicial a $96^{\circ} \mathrm{C}$ por $2 \mathrm{~min}$; anelamento por 35 ciclos $\left(45 \mathrm{~s}\right.$ a $96^{\circ} \mathrm{C}$; $30 \mathrm{~s}$ a $48-50^{\circ} \mathrm{C}$ e $5 \mathrm{~min}$ a $60^{\circ} \mathrm{C}$. O produto dessa reação foi precipitado pela adição de isopropanol 75\%, agitado no vórtex e incubado por 15min a temperatura ambiente; posteriormente centrifugado e o sobrenadante descartado; o precipitado foi seco a temperatura ambiente e posteriormente lavado com etanol 70\% e em seguida centrifugado novamente. 
Sequênciamento do DNA

Os sequênciamentos foram realizados em sequênciadores automatizados ABI Genetic Analyzer ${ }^{\circledR}$ do Departamento de Biologia da Faculdade de Filosofia, Ciências e Letras de Ribeirão Preto, Universidade de São Paulo, no Departamento de Tecnologia da Faculdade de Ciências Agrárias e Veterinárias de Jaboticabal, Universidade Estadual Paulista dentro do Laboratório Multiusuário Centralizado para Sequênciamento de DNA em Larga Escala e Análise de Expressão Gênica da Universidade Estadual Paulista "Júlio de Mesquita Filho" (UNESP), e no Departament of Biology of the University of Louisiana-Lafayette por meio do kit de reação ABI Big Dye ${ }^{\circledR}$ Terminator Mix (Applied Biosystems).

\section{Edição das sequências}

Todas as sequências obtidas foram confirmadas pelo sequênciamento de ambas as fitas e construção de uma sequência consenso pelo programa computacional BioEdit 7.0.5. (Hall, 2005) e Sequencher 4.1 software (Gene Codes Corp., Ann Arbor, MI, USA). Todas as fitas obtidas foram previamente submetidas ao alinhamento no sistema BLAST no intuito de compará-las com a base de banco de dados NCBI (http://blast.ncbi.ncbi.nlm.nih.gov/blast.cgi) visando confirmar a identificação. No entanto, não existe qualquer sequência de espécies do gênero Persephona no banco de dados, apenas poucas espécies pertencentes à família Leucosiidae. Assim, ao comparar as sequências obtidas com a base de dados, foi possível observar similaridade com sequências identificadas como Brachyura, algumas com o gênero Ebalia e com outras bastante distintas evolutivamente, como sequências do gênero Munida.

As sequências obtidas de fragmentos dos genes mitocondriais $16 \mathrm{~S}$ e COI foram previamente editadas e alinhadas no programa ClustalW (Thompson et al., 1994), com interface no BioEdit, para a eliminação de possíveis erros que 
pudessem interferir no resultado das análises. Estas também foram traduzidas no intuito de verificar a existencia de pseudogenes, os quais poderiam prejudicar as análises, a partir da verificação da presença de stop códons no quadro de leitura. Posteriormente as sequencias foram submetidas no banco de dados genéticos - Genbank (ver números de acesso na Tabela III).

Foram incluídas nas análises as sequências obtidas das dez espécies consideradas válidas atualmente, $P$. aquilonaris, $P$. crinita, $P$. edwardsii, $P$. finneganae, P. lichtensteinii, P. mediterranea, P. orbicularis, P. punctata, P. subovata e P. townsendi, bem como a sequência disponibilizada no Genbank para Ebalia (Tab. III). Devido à ausência de trabalhos que indiquem as relações filogenéticas da família Leucosiidae, foram adotados como grupo externo, representantes dos gêneros Acanthilia, Ebalia, Goniopsis e Iliacantha, na tentativa de testar o monofiletismo do gênero. Vouchers genéticos de tecidos de subamostras foram obtidos e depositados nas respectivas coleções de origem, cujo acesso encontrase na tabela III.

Poucas são as sequências disponíveis da família Leucosiidae no Genbank. Assim, para as análises, foi utilizada sequência da espécie Ebalia nux (Marrocos) que apesar da distribuição distinguir das espécies analisadas, foi, porém, a espécie disponível no banco de dados para enraizamento das árvores, utilizada juntamente com algumas espécies do gênero Acanthilia, Iliacantha e Goniopsis. 
Tabela III. Espécimes de caranguejos usados nas análises moleculares com respectiva data e local de coleta, número de catálogo de museu e número de acesso do banco de dados genético (Genbank). (CCDB - Coleção de Crustáceos do Departamento de Biologia, FFCLRP, USP; CNCR - Colección Nacional de Crustáceos, Instituto de Biología, UNAM; MZUSP - Museu de Zoologia da Universidade de São Paulo; UF- University of Florida; ULLZ - University of Louisiana at Lafayette's Zoology Collection; USNM - United States National Museum - Smithsonian, Washington DC/USA). BRA - Brasil; COL - Colômbia; CRI - Costa Rica; EUA - Estados Unidos; HON - Honduras; MAR - Marrocos; MEX - México; PAN - Panamá; VNZ - Venezuela.

\begin{tabular}{|c|c|c|c|c|}
\hline \multirow{2}{*}{ Espécie } & \multirow{2}{*}{ Local de coleta, data } & \multirow[t]{2}{*}{ № de catálogo } & \multicolumn{2}{|c|}{ № de acesso GenBank } \\
\hline & & & COI & $16 S$ \\
\hline Persephona crinita Rathbun, 1931 & Texas (EUA), 1979 & ULLZ 1847 & JX102076 & JX102059 \\
\hline Persephona crinita Rathbun, 1931 & Louisiana (EUA), - & ULLZ 11959 & JX102077 & JX102068 \\
\hline Persephona crinita Rathbun, 1931 & Maceió, AL (BRA), 1999 & MZUSP 21087 & JX102075 & - \\
\hline Persephona crinita Rathbun, 1931 & Ilhéus, BA (BRA), 1994 & MZUSP 21088 & JX102074 & JX102060 \\
\hline Persephona edwardsii Bell, 1855 & (PAN), 2007 & ULLZ 13932 & JX102092 & JX102070 \\
\hline Persephona finneganae Rathbun, 1931 & (VNZ), 1969 & USNM 1155108 & JX102079 & JX102065 \\
\hline Persephona finneganae Rathbun, 1931 & Cachoeiro do Itapemirim, ES (BRA), 1982 & MNRJ 733 & JX102078 & - \\
\hline Persephona lichtensteinii Leach, 1817 & (HON), 1979 & ULLZ 2002 & JX102084 & JX102069 \\
\hline Persephona lichtensteinii Leach, 1817 & (COL), 1996 & USNM 1072260 & JX102085 & JX102064 \\
\hline Persephona lichtensteinii Leach, 1817 & Ilhéus, BA (BRA), 1994 & MZUSP 21091 & JX102081 & - \\
\hline Persephona lichtensteinii Leach, 1817 & Maceió, AL (BRA), 1990 & MZUSP 21096 & JX102082 & - \\
\hline Persephona lichtensteinii Leach, 1817 & Ubatuba, SP (BRA), 2009 & CCDB 0023 & JX102080 & - \\
\hline Persephona lichtensteinii Leach, 1817 & Ubatuba, SP (BRA), 1999 & CCBD 1430 & - & JX102061 \\
\hline Persephona lichtensteinii Leach, 1817 & Ubatuba, SP (BRA), 1999 & CCBD 1430 & - & JX102062 \\
\hline Persephona lichtensteinii Leach, 1817 & Bombinhas, SC (BRA), 1995 & MZUSP 13102 & JX102083 & - \\
\hline Persephona mediterranea (Herbst, 1794) & Texas, (EUA), 1979 & ULLZ 1840 & JX102089 & JX102066 \\
\hline Persephona mediterranea (Herbst, 1794) & Golfo do México (EUA), 1979 & ULLZ 1997 & JX102088 & - \\
\hline Persephona mediterranea (Herbst, 1794) & Ubatuba, SP (BRA), 2011 & CCDB 1581 & JX102087 & - \\
\hline Persephona mediterranea (Herbst, 1794) & Ubatuba, SP (BRA), 2009 & CCDB 2662 & JX102086 & JX102067 \\
\hline Persephona puctata (Linnaeus, 1758) & Ubatuba, SP (BRA), 2011 & CCDB 1539 & JX102090 & JX102063 \\
\hline Persephona orbicularis Bell, 1855 & (CRI), 2009 & CCDB 2940 & JX102091 & - \\
\hline Persephona subovata (Rathbun, 1894) & Oaxaca (MEX), - & CNCR 3269 & JX102093 & - \\
\hline Persephona townsendi (Rathbun, 1894) & (PAN), 2007 & ULLZ 13931 & JX102094 & JX102071 \\
\hline \multicolumn{5}{|l|}{ Grupo Externo } \\
\hline Acanthilia intermedia (Miers, 1886) & Golfo do México, 2006 & ULLZ 8161 & - & JX102072 \\
\hline Ebalia nux A. Milne-Edwards, 1883 & (MAR), 2004 & - & JQ348856.1 & - \\
\hline Goniopsis cruentata (Latreille, 1803) & Ilha Comprida, SP (BRA), 2011 & CCDB 785 & JX102096 & - \\
\hline Iliacantha hancocki Rathbun, 1935 & (CRI), 2009 & CCDB 2834 & JX102095 & - \\
\hline Iliacantha intermedia (Miers, 1886) & Flórida (EUA), - & UF 15151 & Não disponível & \\
\hline Iliacantha subglobosa Stimpson, 1871 & (MEX), 2005 & ULLZ 7069 & - & JX102073 \\
\hline Iliacantha subglobosa Stimpson, 1871 & Flórida (EUA),- & UF 3968 & Não disponível & - \\
\hline
\end{tabular}


Qualidade dos dados

No intuito de checar a qualidade dos dados, foi realizada a verificação do grau de saturação de transições e do sinal filogenético.

De acordo com Xia \& Lemey (2009), o dados com qualidade para representar a história evolutiva de um grupo não podem exibir uma taxa de substituição muito baixa, que não seja possível verificar a divergência genética. Mas também não deve exibir uma taxa muito elevada, indicando saturação de substituição, em que o número de transversões supera o de substituições, havendo diminiuição da informação filogenética. Para a verificação de saturação foi realizada a plotagem do número de número de transições e transversões versus a divergência, utilizando a distância de TN93 (Tamura \& Nei, 1993) no programa DAMBE (Xia \& Xie, 2001).

Segundo Hillis \& Huelsenbeck (1992), as sequências de DNA, podem conter sinal filogenético ou estarem randomizadas em relação à história filogenética. Essa randomização pode ocorrer a partir da presença de ruídos aleatórios em função de taxas bastante elevadas de alteração de bases (Hillis, 1991). Dessa maneira, o método estatístico G1 (Hillis, 1991; Hillis \& Huelsenbeck, 1992) foi realizado no programa PAUP 4.0 (Phylogenetic Analysis Using Parsimony e other methods) (Swofford, 2003), examinando o grau de assimetria de uma distribuição dos valores das árvores filogenéticas. Esse método realiza uma amostragem ao acaso das árvores, a partir do conjunto de todas as árvores possíveis, e computa os escores de acordo com o critério escolhido (Schneider, 2007). O resultado obtido é representado por um gráfico de distribuição de frequência de escores, com alguns parâmetros calculados, como média, desvio padrão e valor da estatística G1 (Schneider, 2007). Segundo Hillis \& Huelsenbeck (1992) as distribuição tornam-se mais assimétricas para a esquerda com o aumento do sinal filogenético, ou seja, o gráfico de distribuição apresenta-se mais deslocado para a direita. Distribuição de escores 
relativamente simétrica tende a indicar dados com pouco ou nenhum sinal filogenético (Schneider, 2007).

\section{Análise de distância genética}

No intuito de checar a divergência genética entre as espécies foi realizada uma análise de cluster no programa PAUP 4.0 e então foram calculadas as distâncias inter e intraespecíficas dos espécimes de Persephona, através da comparação de par a par ou pares do modelo de substituição de distância não corrigida ou distância $p$, método geométrico que analisa a proporção de posições divergentes entre duas sequências para o número de nucleotídeos. Embora essa análise não leve em consideração múltiplas substituições, ainda é efetiva quando a distância média entre as espécies é menor que 20\% (Nei, 1991; Russo et al., 2001), o que pôde ser observado para ambos os genes em Persephona.

\section{Análises filogenéticas}

No intuito de testar as relações internas do gênero Persephona, foram realizadas análises filogenéticas utilizando o critério de Máxima Verossimilhança (MV) e a Máxima Parcimônia (MP) para ambos os genes mitocondriais $16 \mathrm{~S}$ e COI.

\section{- Máxima Verossimilhança (MV)}

O método de MV tenta inferir a árvore evolutiva por meio da busca pela árvore que maximiza a probabilidade de observação dos dados, ou seja, calcula a árvore de maior probabilidade de ocorrência, podendo levar em consideração parâmetros como taxa de substituição e frequência de bases, a partir de um modelo evolutivo escolhido (Russo et al., 2001; Hall, 2011). Para a análise de MV, o modelo evolutivo assumido foi o General Time Reversible (GTR) + Gamma (G) + Proporção Invariante (I), inserido na base do RAxML 7.2.7 
("Randomized Axelerated Maximum Likelihood") (Stamatakis, 2006) através do portal CIPRES (Cyberinfrastructure for Phylogenetic Research, www.phylo.org).

A consistência interna dos ramos foi avaliada pelo método de "bootstrap" (Felsenstein, 1985) e apenas valores de confiança acima de 50\% foram apresentados.

A árvore produzida foi vizualizadas e editada no programa FigTree v1.3.1 (Rambaut, 2009) e posteriormente os nomes dos taxa editados no programa Photoshop Adobe Photoshop CS3.

\section{- Máxima Parcimônia (MP)}

A outra análise filogenética realizada foi a MP, a qual busca pela árvore com menor número de passos, assumindo a mais parcimoniosa. As análises foram realizadas no programa POY 5.0.1 (Varón et al., 2010), o qual apresenta um método de análise dinâmica, sob otimização direta com a MP como critério de otimização (Wheeler, 1996). Nesta análise, a homologia entre os pares de bases é inferida como um processo dinâmico, no qual a partir de cada alinhamento é gerada uma árvore e o melhor alinhamento e melhor árvore (com menor custo) são armazenados (Varón et al., 2010). A consistência interna dos ramos foi avaliada pelo método de suporte de Bremer (1988), o qual indica quantos passos adicionais seriam necessários para se colapsar um ramo na árvore consenso (Bremer, 1994). Assim, os ramos com baixos valores não são bem suportados.

A árvore produzida foi vizualizadas e editada no programa FigTree v1.3.1 (Rambaut, 2009) e posteriormente os nomes dos taxa editados no programa Photoshop Adobe Photoshop CS3. 


\subsection{Análises Morfológicas}

Foi analisado um total de 286 espécimes das espécies $P$. aquilonaris, $P$. crinita, P. edwardsii, P. lichtensteinii, P. mediterranea, P. orbicularis, P. punctata, P. subovata e P. townsendi oriundos do Brasil, Colômbia, Costa Rica, Estados Unidos, Honduras, México, Panamá e Venezuela (Fig. 2 - não considerando a revisão e sinonímias).

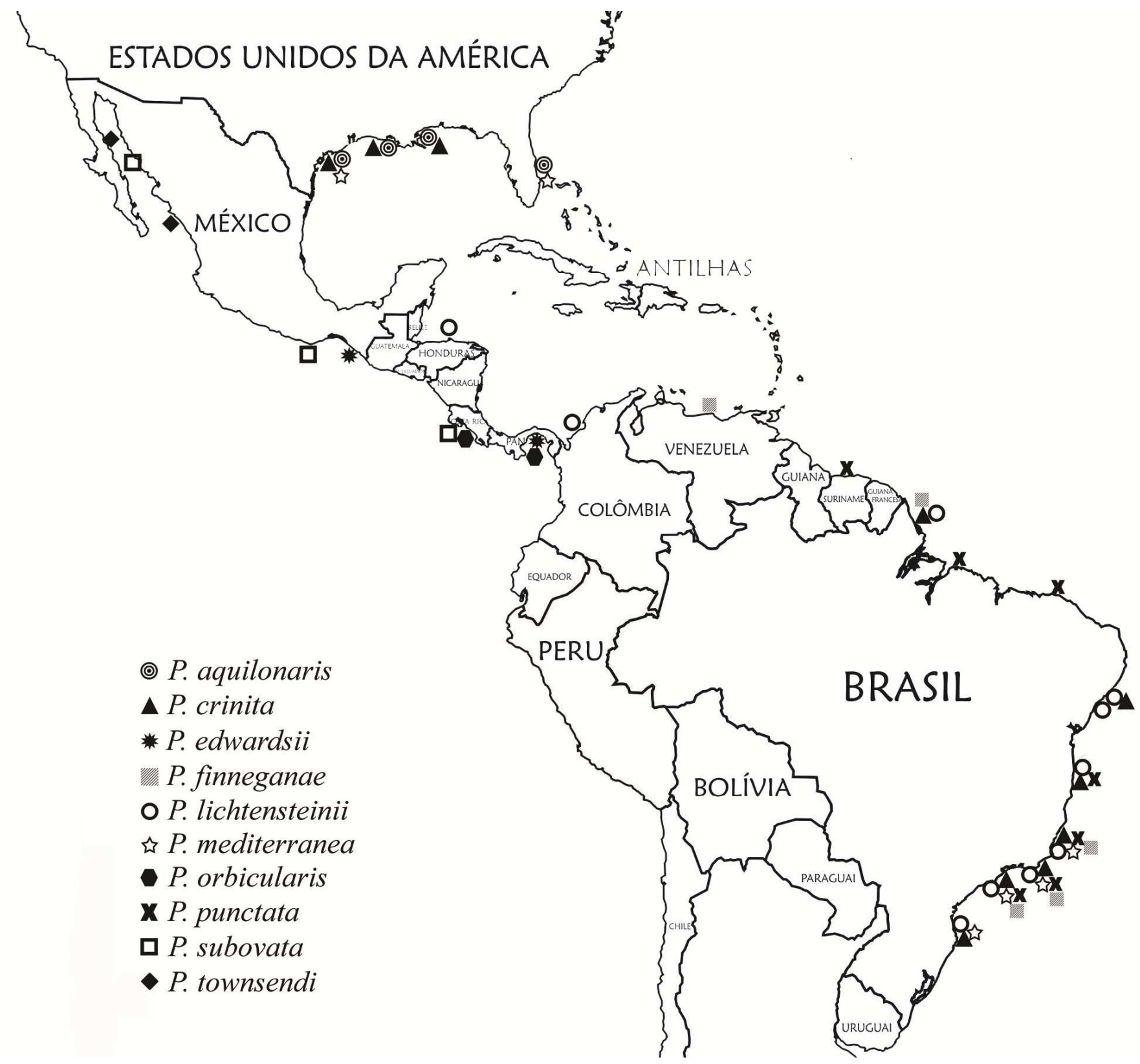

Figura 2. Mapa com a distribuição por países e estados (Brasil e Estados Unidos) dos espécimes de Persephona utilizados nas análises morfológicas, sem considerar a revisão táxonômica. 


\section{Sistemática}

Subfilo Crustacea Pennant, 1777

Ordem Decapoda Latreille, 1803

Subordem Pleocyemata Burkenroad, 1963

Infraordem Brachyura Latreille, 1803

Seção Eubrachyura Saint Laurent, 1980

Superfamilia Leucosoidea Samouelle, 1819

Familia Leucosiidae Samouelle, 1819

Subfamilia Ebaliinae Stimpson, 1871

Gênero Persephona Leach, 1817

Persephona aquilonaris Rathbun, 1933 (Fig. 3)

Guaia punctata: Gibbes, 1850

Persephona punctata aquilonaris: Rathbun, 1933: 184; 1937: 154, pl. 42, fig. 6,7; Humes, 1941: 102; - Behre, 1950: 23; - Hildebrand, 1954: 276; - Wass, 1955: 154; Holthuis, 1959: 183; - Williams, 1965: 150, fig. 127; - Walker, 1974: 681; Overstreet \& Heard, 1978: 132; - Abreu, 1980: 3.

Persephona aquilonaris: - Guinot-Dumortier, 1959: 429 (não P. aquilonaris Rathbun, 1933); - Tabb \& Manning, 1961: 600; - Fausto-Filho, 1968: 44 (não $P$. aquilonaris Rathbun, 1933); - Rouse, 1970: 24, fig. 65; - Coelho \& Ramos, 1972: 183; - Felder, 1973: 42, pr. 5, fig. 4; - William, 1974: 24, fig. 65; - Taissoun, 198688: 132,133; - Ortíz \& Olcha, 2011: 51.

Persephona mediterranea: - Guinot-Dumortier, 1959: 429; - Powers, 1977: 39 (não P. mediterranea Herbst, 1794); - Williams, 1984: 288, fig. 223 (não $P$. mediterranea Herbst, 1794); - Abele \& Kim, 1986: 487, fig. i (não P. mediterranea 
Herbst, 1794); - Raz-Guzman \& Sánchez, 1992: 611 (não P. mediterranea Herbst, 1794).

Persephona punctata acquilonaris: Collins et al., 2009: 28 (erro).

Localidade-tipo: St. Augustine, Flórida, Estados Unidos.

Material-tipo: Holótipo macho $(42,62 \mathrm{~mm})$ de $P$. p. aquilonaris. National Museum of Natural History (Smithsonian Institution), Washington DC, (USNM 62057). Analisado.

Material examinado: Holótipo (USNM 62057). Estados Unidos: Texas 01 macho (45,64mm) (ULLZ 1514); Mississipi 01 macho e 01 juvenil $(20,75 \mathrm{~mm} \pm 4,79)$ (ULLZ 9407); Louisiana 01 macho e 01 fêmea (31,91mm8,39) (ULLZ 3382 3379); Flórida 02 machos, 01 fêmea e 01 juvenil (32,05mm¹0,99) (USNM 2092 62057) (ULLZ 10158).

Diagnose: Três espinhos na carapaça, presentes na margem posterior. Coloração bege com pigmentação vermelha-castanho; pigmentação mais coalescente na porção ântero-dorsal da carapaça e não formando padrões definidos e delimitados de manchas. Gonópodo (pleópodo 1) com ausência de lobo proeminente no bordo látero-distal. Fronte proeminente.

Redescrição: superfície dorsal da carapaça coberta por grânulos diminutos espaçados, visíveis a olho nu; regiões da carapaça mal definidas; carapaça, excluindo os espinhos posteriores, aproximadamente tão longa quanto larga; fêmeas aparentemente com a carapaça mais larga do que longas; formato subglobular. Três espinhos ou dentes na margem posterior, sendo um superior normalmente cilíndrico e dois inferiores um pouco mais comprimidos na base 
no eixo dorso-ventral, podendo apresentar extremidade curvada para cima; margem subhepática sinuosa, podendo ou não conter um grânulo ou proeminência; presença de uma linha definida de grânulos entre os espinhos posteriores inferiores; presença de uma linha lateral definida de grânulos (proeminente na porção anterior, diminuindo na porção posterior, até a região intestinal), dividindo a região dorsal e ventral. Fronte proeminente, bipartida com um "v" na porção mediana; menos de 2,5 vezes mais larga do que longa. Meropodito do terceiro maxilipodo com grânulos diminutos espaçados; isqueopodito com aproximadamente 2/3 internos liso; coxopodito com grânulos diminutos na porção distal; exopodito e basepodito com grânulos diminutos espaçados. Quelípodos delgados, mero totalmente coberto por grânulos, que diminuem de tamanho da parte proximal para a distal; própodo aproximadamente 3 vezes mais longo do que largo; presença de pequenos dentes entre os dedos móvel e fixo; presença de carenas ao longo de ambos os dedos. Patas ambulatórias sem grânulos; ausência de linha de cerdas na margem dorsal do própodo; presença de carenas e cerdas no dáctilo; dáctilo com formato espatuliforme. Gonópodo (pleópodo 1) longo; bordo lateral e mesial estreitos; porção distal estreita com presença de cerdas longas e proeminentes; ausência de lobo proeminente no bordo látero-distal; ausência de ornamentação; sutura marginal na face ventral; ausência de cerdas subapicais; abertura distal larga e direcionada para a face ventral. Coloração bege com pigmentação vermelha-castanho; ausência de pigmentação em uma linha mediana estreita (aproximadamente 0,05 vezes a largura da carapaça) no eixo ântero-posterior, da fronte até aproximadamente a região intestinal; pigmentação mais coalescente na porção ântero-dorsal da carapaça, dispersando em direção a porção posterior e lateral; presença de pigmentos formando pequenas manchas na região posterior, quelípodos e pereiópodos. 
Distribuição: Nova Jersey até Golfo do México.

Observações: A partir das análises dos espécimes de P. mediterranea provenientes do Brasil e P. aquilonaris provenientes do Golfo do México (Texas, Louisiana, Mississipi e Flórida) foi possível verificar um distinto padrão de coloração nos espécimes que ainda preservaram a pigmentação, entre ambos os táxons. Caráter esse que, juntamente com a morfologia distinta do gonópodo, indicam separação entre espécimes dos dois grupos. No entanto uma ampla discussão é realizada nas observações de $P$. mediterranea.

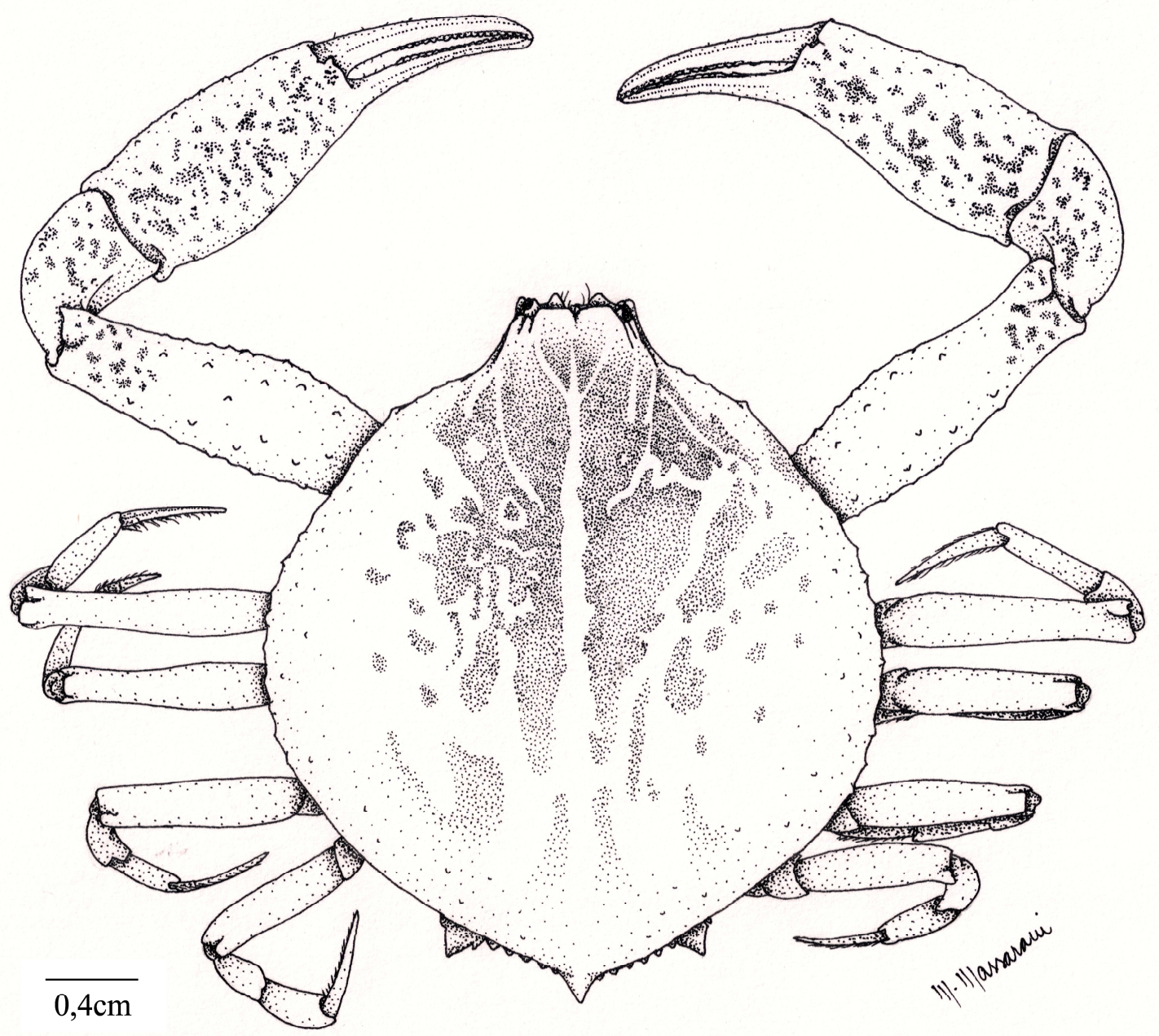

Figura 3. Persephona aquilonaris Rathbun, 1933. Vista dorsal. Fêmea (ULLZ 9407), $C C=30,68 \mathrm{~mm}$. 


\section{Persephona crinita Rathbun, 1931 (Fig. 4)}

Persephona crinita: Rathbun, 1931: 128; 1937: 163 pr. 43, fig. 2,3, pr. 44, fig. 1-3; Compton, 1962: 11; - Rodriguez, 1980: 256; - Abele \& Kim, 1986: 487, fig. e; Melo, 1996: 151 (fig. e mapa) (não P. crinita Rathbun, 1931); - Camp et al., 1998: 146; - Alvaréz et al., 1999: 10; - Mantelatto \& Fransozo, 2000: 703 (não P. crinita Rathbun, 1931); - Severino-Rodrigues et al., 2002: 36 (não P. crinita Rathbun, 1931); - Bertini et al., 2004: 2204 (não P. crinita Rathbun, 1931); - Ng et al., 2008: 92; - Felder \& Camp, 2009: 1075; - Moreira, 2011: 26; - Hirose et al., 2012: 17 (não P. crinita Rathbun, 1931).

Localidade-tipo: Horn Island Pass, Mississipi.

Material-tipo: Síntipos 01 macho $(21,04 \mathrm{~mm}), 01$ fêmea $(24,87 \mathrm{~mm})$ e 01 juvenil (17,53mm) de P. crinita, Horn Island Pass, Mississipi (EUA). National Museum of Natural History (Smithsonian Institution), Washington DC, (USNM 64254). Analisado.

Material examinado: Síntipo (USNM 64254) Estados Unidos: Texas 02 machos e 02 juvenis (20,30mm³,30) (ULLZ 19958485 1847) (USNM 1155109); Mississipi 02 machos, 01 fêmea e 01 juvenil $(22,68 \mathrm{~mm} \pm 4,41)$ (ULLZ 879); Louisiana 02 machos, 02 fêmeas e 03 juvenis (20,29mm¹,63) (ULLZ 3902119591195611942 33493350 3343); Brasil: Amapá, 01 macho (23,05mm) e 01 fêmea (17,96mm) (“MNRJ 1456”); Alagoas, Maceió 01 fêmea (21,74mm) (“MZUSP 21087”); Bahia, Ilhéus 03 machos e 01 fêmea $(25,62 \mathrm{~mm} \pm 3,94)$ (“MZUSP 21088, 21090, 21091"); Espírito Santo, Regência 01 juvenil (6,01mm) (“MNRJ 16163”); São Paulo, Caraguatatuba 01 fêmea (26,17mm) (“CCDB 759”); Ubatuba 03 machos e 06 
fêmeas $(23,68 \mathrm{~mm} \pm 5,82)$ (“CCDB 009, 011, 015, 019, 023, 2857"); Santa Catarina, São Francisco do Sul 01 macho (26,02mm) (“MNRJ 1457”).

“" espécimes identificados como $P$. crinita nas etiquetas de instituições visitadas; entretanto, estas devem modificar a identificação para P. lichtensteinii.

Diagnose: Três espinhos e quatro tubérculos na carapaça; três espinhos curtos ou tubérculos na margem posterior, dois tubérculos na margem lateral e dois tubérculos na margem subhepática. Fronte não proeminente.

Redescrição: superfície dorsal da carapaça esparsamente granulada, com grânulos pequenos; presença de cerdas curtas; cobertura mais densa na porção ântero-lateral da carapaça; carapaça, excluindo os espinhos posteriores, tão longa quanto larga; aparentemente mais larga do que longa nas fêmeas; formato subglobular. Presença de três tubérculos na porção posterior, quatro tubérculos muito curtos, dois no meio da margem lateral e dois na margem subhepática; um pequeno tubérculo pode ou não aparecer entre os tubérculos laterais e subhepáticos; ausência de uma linha de grânulos entre os espinhos posteriores inferiores; ausência de uma linha definida de grânulos dividindo a margem dorsal e ventral. Ausência de uma linha definida de grânulos entre os espinhos posteriores inferiores; ausência de uma linha definida de grânulos dividindo a região dorsal a ventral. Fronte bipartida, ampla e curta, aproximadamente 4 vezes mais larga do que longa; presença de um " $v$ " na porção mediana. Terceiro maxilípodo com 2/3 interno do ísquiopodito liso; coxopodito, basepodito e exopodito esparsamente granulados. Quelípodos maciços, mero constrito próximo ao carpo, com proeminente granulação na porção proximal, reduzindo na porção distal; presença de grânulos na margem interna do carpo; própodo com presença de pequenos grânulos na margem lateral proximal; presença de cerdas e dentes irregulares entre os dedos; 
própodo aproximadamente 4 vezes mais longo do que largo; dedos delgados e sulcados, com presença de hiato variável. Dáctilos das patas ambulatórias com formato espatuliforme; presença de duas fileiras de cerdas, uma na margem superior e outra na margem inferior; Regiões da carapaça mal definidas. Esternitos e episternitos com grânulos pequenos e espaçados. Gonópodo (pleópodo 1) longo; bordo lateral e mesial estreitos; porção distal estreita; ausência de lobo proeminente no bordo látero-distal; ausência de ornamentação; sutura marginal na face ventral; presença de tufo de cerdas subapicais; abertura distal estreita e direcionada para a face dorsal.

Distribuição: Golfo do México.

Observações: Os espécimes de P. crinita provenientes do Atlântico Sul, apresentaram caracteres muito semelhantes aos espécimes de P. lichtensteinii, como espinhos posteriores, espinhos da margem lateral e da margem subhepática apresentando tamanhos variados. No entanto, diferindo-se dos exemplares de P. crinita do Golfo do México, os quais apresentaram grânulos bastante curtos na margem lateral e na margem subhepática da carapaça. Uma discussão mais ampla sobre essa problemática é realizada nas observações de $P$. lichtensteinii. 


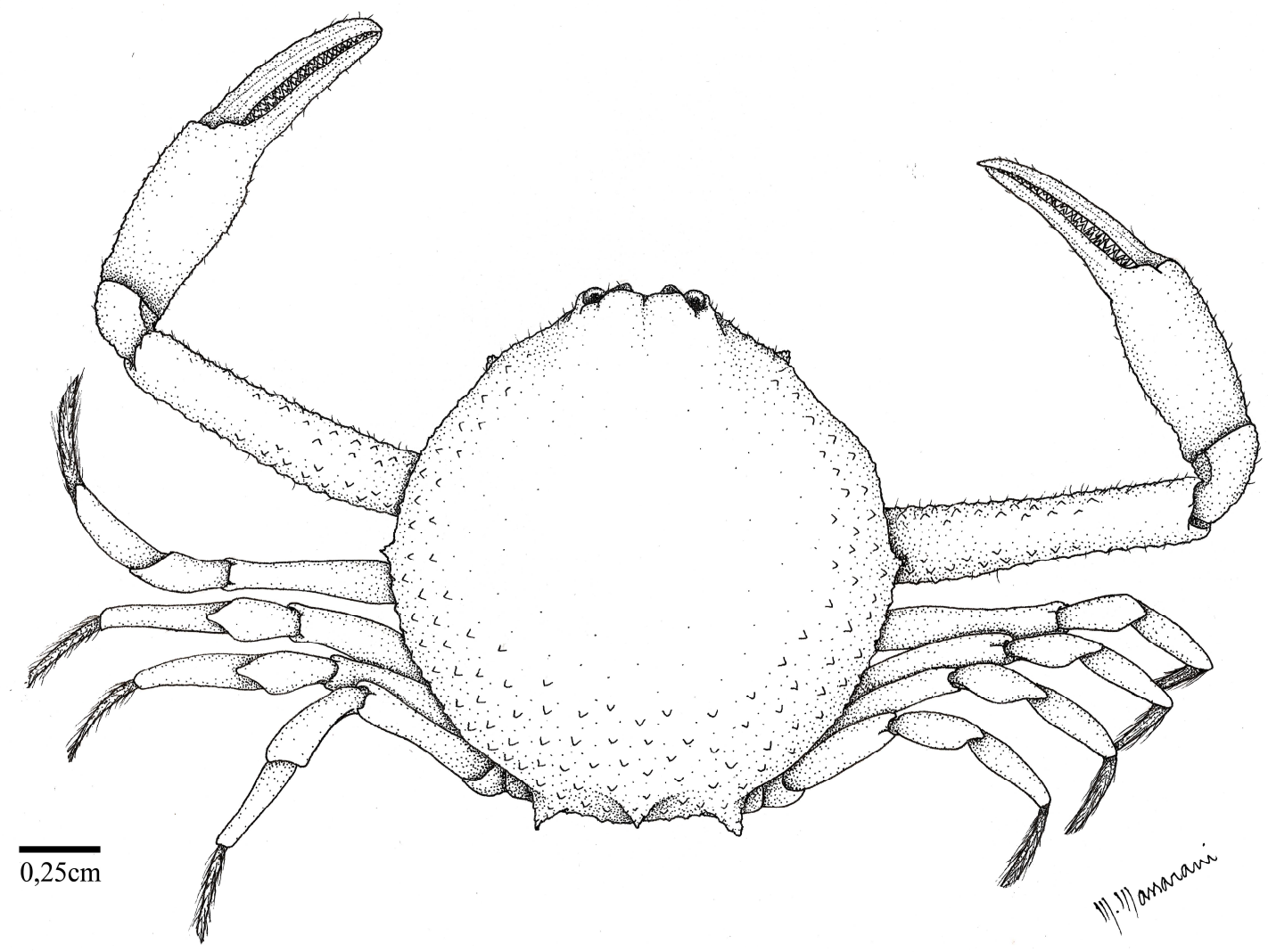

Figura 4. Persephona crinita Rathbun, 1931. Vista dorsal. Macho (ULLZ 1847), $\mathrm{CC}=17,75 \mathrm{~mm}$.

Persephona edwardsii Bell, 1855 (Fig. 5)

Persephona edwardsii: Bell, 1855: 294, lam. 31, fig. 8; - Stimpson, 1859: 70; Rathbun, 1937: 154, lam. 45, figs. 3-4; - Garth, 1946: 358; 1960: 121; 1966: 9; Buitendijk, 1950: 270; - Del Solar et al., 1970: 26; - Sosa-Hernández et al., 1980: 17, lam. 3; - Correa-Sandoval, 1991: 12; - Hendrickx, 1993: 8; 1995: 129; 1997: 146.

Localidade-tipo: Ilhas Galápagos.

Material-tipo: sexo não definido por Bell. Museu Britânico. Não analisado.

Material analisado: México: Chiapas 02 machos (31,37mm4,81) (CNCR 18997); Panamá: 01 juvenil (12,98mm) (ULLZ 13932). 
Diagnose: Três espinhos na carapaça presentes na margem posterior. Quelípodos menos de duas vezes mais longa do que larga; presença de tufos de cerdas nas margens internas de carpo, mero e própodo.

Redescrição: superfície da carapaça levemente granulada; grânulos diminutos, pouco visíveis a olho nu; carapaça, excluindo os espinhos posteriores, aproximadamente tão longa quanto larga; formato subglobular, mais estreita na porção anterior. Ausência de uma linha definida de grânulos entre os espinhos posteriores inferiores; ausência de uma linha definida de grânulos dividindo a região dorsal a ventral. Fronte pouco pronunciada, aproximadamente 3 vezes mais larga do que longa; bipartida com um "v" na porção mediana. Presença de três espinhos posteriores, longos e cilíndricos. Isqueopodito do terceiro maxilípodo com 2/3 da porção proximal liso; meropodito com grânulos presentes na porção distal, diminutos; exopodito praticamente liso; coxopodito com grânulos pequenos e espaçados. Quelípodo com presença de tufos de cerdas contínuos ao longo da margem externa e interna do mero, carpo e própodo; mais denso na margem interna de cada segmento; própodo aproximadamente 3,5 vezes mais longo do que larga. Patas ambulatórias com cerdas na margem inferior do própodo; presença de carenas e cerdas no dáctilo; dáctilo com formato espatuliforme. Gonópodo (pleópodo 1) longo; bordo lateral e mesial estreitos; porção distal estreita e tubular; ausência de lobo proeminente no bordo látero-distal; ausência de ornamentação; sutura marginal na face ventral; presença de linha de cerdas que partem do bordo latero-distal e chegam até o bordo latero-subapical; abertura distal estreita. 
Distribuição: Pacífico Oriental- de Baixa Califórnia do Sul até Perú; Ilhas Galápagos.

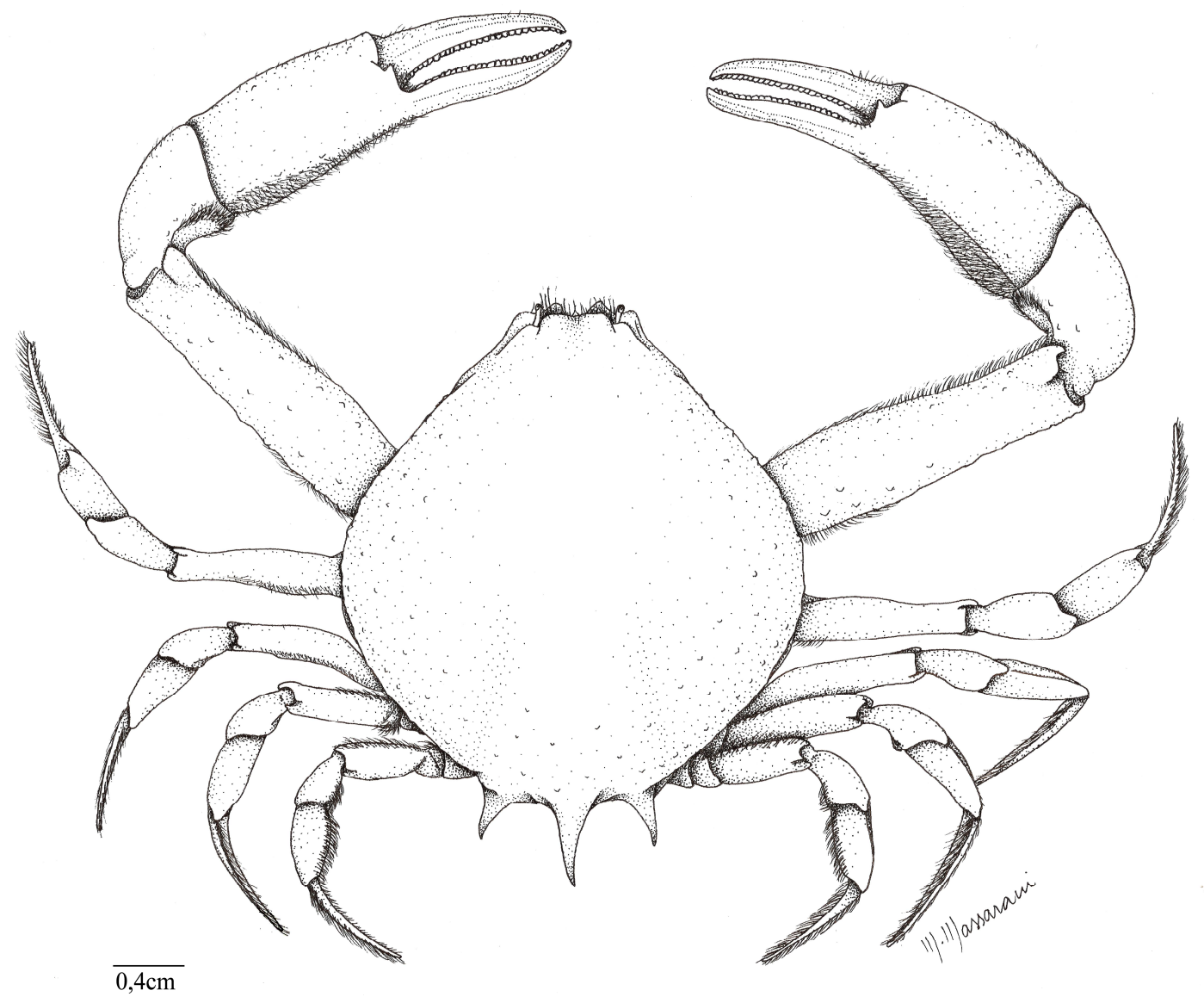

Figura 5. Persephona edwardsii Bell, 1855. Vista dorsal. Macho (CNCR 18997), $\mathrm{CC}=34,78 \mathrm{~mm}$.

Persephona lichtensteinii Leach, 1817 (Fig. 8)

Persephona lichtensteinii: Leach, 1817: 23; - Bell, 1855: 293, pr. 31, fig. 6 (não $P$. lichtensteinii Finnegan, 1931); - Rathbun, 1937: 163, pr. 45, figs. 1-2; - Holthuis, 1959: 181; - Rodriguez, 1980: 255; - Coelho \& Ramos, 1972: 183; - Gomes-Corrêa \& Silva-Brum, 1980: 61; - Coelho et al., 1983: 154; - Takeda, 1983: 115, fig. s/n; Coelho et al., , 1986: 74; - Hyodo, 1996: 4, fig. 1; - Melo, 1996: 152 (fig e mapa); Torres, 1998: 106, fig. 27; - Rieger et al., 1999: 193, fig. 1; - Mantelatto \& Fransozo, 2000: 702; - Severino-Rodrigues, 2002: 36; - Mantelatto et al., 2003: 212; - Bertini 
et al., 2004: 2190; - Almeida et al., 2008: 32; - Coelho et al., 2008: 15; - Ng et al., 2008: 93; - Carvalho et al., 2010: 109; - Hirose et al., 2012: 17.

Persephone lichtensteini: - Moreira, 1903: 120; - Luederwaldt, 1919: 435.

Persephona lichtensteini: - Finnegan, 1931: 614 (não P. lichtensteinii Leach, 1817 ou P. lichtensteinii Bell, 1855); - Coelho, 1969; - Werding \& Müller, 1989: 410, fig. 5.

Persephona finneganae: - Rathbun, 1933: 184; 1937: 161, fig. 37; - GuinotDumortier, 1959: 434, fig. 8, a-c; - Coelho, 1969; - Coelho \& Ramos, 1972: 183; Gomes-Corrêa \& Silva-Brum, 1980: 61; - Coelho et al., 1983: 154; 1986: 74; Coelho \& Ramos-Porto, 1986: 74; - Taissoun, 1986-88: 128, 129 (fig.); - Ng et al., 2008.

Persephona crinita: - Coelho \& Ramos, 1972: 183 (não P. crinita Rathbun, 1931); - Coelho \& Torres, 1980: 72 (não P. crinita Rathbun, 1931); - Coelho et al., 1986: 74 (não P. crinita Rathbun, 1931); - Melo, et al., 1989: 5 (não P. crinita Rathbun, 1931); - Melo, 1996: 151 (fig. e mapa) (não P. crinita Rathbun, 1931); - Mantelatto \& Fransozo, 2000: 703 (não P. crinita Rathbun, 1931); - Severino-Rodrigues, 2002: 36 (não P. crinita Rathbun, 1931); - Bertini et al., 2004: 2204 (não P. crinita Rathbun, 1931); - Ng, et al., 2008: 92; - Moreira, 2011: 26; - Hirose et al., 2012: 17 (não P. crinita Rathbun, 1931).

Localidade-tipo: desconhecida.

Material-tipo: tipo 01 macho de $P$. lichtensteinii, localidade não conhecida. Museu Britânico. Não analisado.

Material examinado: Tipo de P. finneganae USNM 67989. Honduras: Graças a Dios, Punta Patuca 01 macho (25,49mm) (ULLZ 2002); Colômbia: Ceycen Island 01 macho (22,01mm) (USNM 1072260); Venezuela: 02 machos $(21,33 \mathrm{~mm} \pm 3,46)$ 
(“USNM 1155107 1155108”); Brasil: Amapá 02 machos e 01 fêmea (23,13mm $\pm 1,51)$ (“MNRJ 328” MZUSP 8575); Alagoas, Maceió 05 machos e 02 fêmeas (22,80mm¹,28) (MZUSP 6530, 6789, 6893, 21096); Sergipe, Pirambu 01 macho (22,68mm) (MZUSP 6616); Bahia, Ilhéus 06 machos e 04 fêmeas $(27,64 \mathrm{~mm} \pm 1,56)$ (MZUESC 298); Espírito Santo, Guarapari 04 machos e 08 fêmeas $(22,60 \mathrm{~mm} \pm 1,28)$ (MZUSP 12160); Cahoeiro do Itapemirim 02 machos e 01 fêmea $(23,27 m m \pm 2,37)$ ("MNRJ 733"); Rio de Janeiro, São Francisco de Itabapoana 06 machos e 07 fêmeas (21,61mm¹,01) (“MNRJ 326" 1460); São João da Barra 02 machos e 04 fêmeas $(22,74 \mathrm{~mm} \pm 1,89)$ (MNRJ 3894); Sepetiba 01 fêmea (23,13mm) (MZUSP 8372), Ilha Grande 01 fêmea $(25,14 \mathrm{~mm})$ (MZUSP 2326); São Paulo, Ubatuba 05 machos, 07 fêmeas e 3 juvenis $(27,10 \mathrm{~mm} \pm 2,91)$ (CCDB 0019002314302525266329392941 3257), São Sebastião 02 machos $(29,65 \mathrm{~mm} \pm 5,63)$ (“USNM 67989” MNRJ3897), Guarujá 01 fêmea (28,58mm) (MZUSP 3370); Santa Catarina 01 macho e 01 fêmea $(25,15 \mathrm{~mm} \pm 0,27)$ (MZUSP 13102).

“" espécimes identificados como $P$. finneganae nas etiquetas das instituições visitadas; entretanto, estas devem modificar a identificação para P. lichtensteinii.

Diagnose: Sete espinhos na carapaça; três na margem posterior, superior usualmente mais longo; dois espinhos na margem lateral e dois espinhos ou dentes na margem subhepática. Fronte não proemiente.

Redescrição: superfície dorsal da carapaça esparsamente granulada, coberta com cerdas curtas, mais intenso na porção ântero-lateral; carapaça, excluindo os espinhos posteriores, tão longa quanto larga; formato subglobular, em alguns espécimes mais estreita na porção posterior; fêmeas aparentemente mais largas. Sete espinhos nas margens da carapaça; três posteriores, superior usualmente mais longo; dois na margem lateral da carapaça; dois espinhos ou dentes na 
margem subhepática, todos podendo variar de tamanho e formato; um pequeno tubérculo pode ou não estar presente entre os espinhos da margem lateral ou subhepática. Ausência de uma linha definida de grânulos entre os espinhos posteriores inferiores; ausência de uma linha definida de grânulos dividindo a região dorsal a ventral. Fronte ampla, bipartida com "v" na porção mediana. Terceiro maxilípodo com $2 / 3$ do ísquiopodito liso; coxopodito, basepodito e exopodito esparsamente granulado. Quelípodo com mero constrito próximo ao carpo; proeminente granulação na parte proximal, principalmente superfície dorsal, reduzindo na porção distal; presença de pequenos grânulos na margem interna do carpo e própodo; presença de cerdas e dentes irregulares entre os dedos; própodo aproximadamente 4 vezes mais longo do que largo; dedos delgados e sulcados, com presença de hiato variável; extremidade do dáctilo excede, menor ou igual o tamanho da extremidade do própodo. Patas ambulatórias sem grânulos, com presença de linha de cerdas na margem dorsal do própodo e superfície dorsal e ventral do dáctilo; dáctilo com formato espatuliforme. Regiões da carapaça mal definidas. Esternitos e episternitos com grânulos pequenos e espaçados. Gonópodo (pleópodo 1) longo; bordo lateral e mesial estreitos; porção distal estreita; ausência de lobo proeminente no bordo látero-distal; ausência de ornamentação; sutura marginal na face ventral; presença de tufo de cerdas subapicais; abertura distal estreita.

Distribuição: Atlântico Ocidental: Mar do Caribe, Honduras, Colômbia, Venezuela, Suriname, Guiana Francesa e Brasil (do Amapá até Santa Catarina).

Observações: Na literatura, a morfologia dos espinhos é uma característica que distingue as espécies do gênero Persephona (Williams, 1984; Rathbun, 1937). No entanto, em uma análise comparativa de espécimes de $P$. crinita, P. finneganae e P. lichtensteinii do Atlântico Sul, verificou-se que os espinhos, dentes ou 
tubérculos da superfície da carapaça são caracteres muito variáveis. Os espécimes identificados como as três espécies apresentaram sete espinhos ou dentes em torno da carapaça, sendo três na margem posterior, dois na margem lateral e dois na margem subhepática. Foi observada variação em relação comprimento, largura e posição dos espinhos, não sendo possível separá-los baseando-se neste caráter. Além disso, a presença de um tubérculo no meio dos espinhos laterais e subhepáticos como mencionados a presença deste por Rathbun (1937) para P. crinita e P. finneganae também foi um caráter bastante variável, podendo estar presente ou ausente.

Entre os espécimes do Brasil, tamanho, número e formato dos espinhos é um caráter não muito informativo, pois este pode estar relacionado à fase de desenvolvimento ou ao hábito de vida desses animais. Os caranguejos leucosídeos apresentam o hábito de se enterrarem (Stevcic, 1973; Taylor, 1984), o que pode causar desgaste e quebra da extremidade dos espinhos.

Quando espécimes adultos e juvenis de P. lichtensteinii foram analisados, observou-se que animais jovens tendem a ter espinhos mais longos e cilíndrico, quando comparados com indivíduos adultos, que tendem a ter espinhos mais curtos e cônicos (Fig. 6). A posição dos espinhos posteriores formando um triângulo equilátero, como descrito por Rathbun (1937) é mais aparente em juvenis, com o desenvolvimento do indivíduo os espinhos tendem a se afastar.
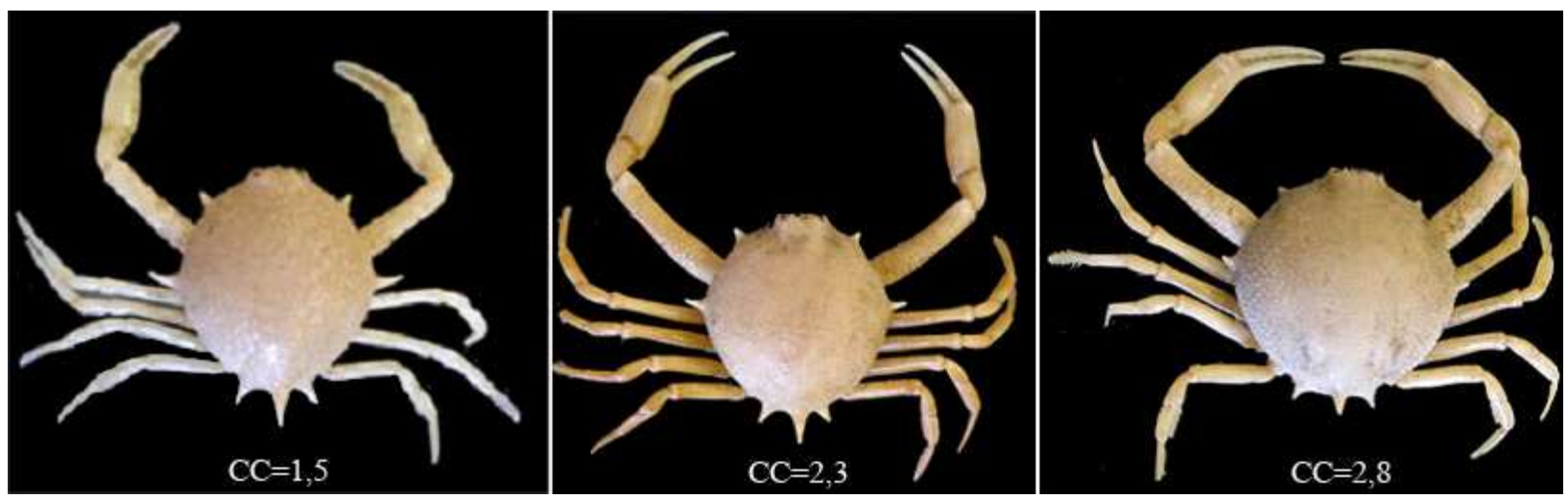

Figura 6. Imagem de espécimes de $P$. lichtensteinii, mostrando diferenças no padrão de tamanho dos espinhos em relação ao comprimento da carapaça $(\mathrm{cm})$. 
Outros caracteres utilizados na revisão como quelípodos, superfície da carapaça, segundo e terceiro maxilípodo, fronte, pereiópodo, estrutura reprodutiva de machos (pleópodo 1), presença de cerdas e grânulos nos espécimes foram muito semelhantes, sem variação que se mantivesse constante nos espécimes analisados do Atlântico Sul. No entanto, ao comparar espécimes da América do Norte (Golfo do México) de P. crinita da ULLZ e USNM, com animais identificados como mesma espécie e mesmo tamanho do Brasil, verificou-se que algumas variações morfológicas foram mantidas. Os espécimes dos Estados Unidos possuem três tubérculos ou dentes curtos na margem posterior, seja juvenil ou adulto, sendo os dois inferiores mais afastados comparados com os espécimes do Brasil. Os animais do Atlântico Sul têm espinhos longos e cilíndricos, principalmente o espinho posterior superior. Além disso, ao invés de espinhos ou dentes nas margens laterais e subhepáticas da carapaça, há tubérculos muito curtos às vezes não distintos, enquanto nos espécimes do Brasil há espinhos, alguns bastante longos e cilíndricos nas margens laterais e um pouco mais curtos nas margens subhepáticas. Adicionalmente observou-se divergências morfológicas que se mantiveram no gonópodo (p1) (Fig. 7).

Rathbun (1931) descreveu P. crinita com a superfície dorsal da carapaça coberta por uma densa camada de cerdas curtas e curvas, que escondem pequenos grânulos esparsos. No entanto, observou-se que a cobertura de cerdas nesses espécimes não é tão densa, sendo mais intensa na porção anterior da carapaça, o que também foi observado por Torres (1998). Além disso, Rathbun (1931) mencionou a presença de um tubérculo entre os espinhos laterais e subhepáticos de P. crinita, no entanto, este caráter foi bastante variável para os mesmos espécimes da América do Norte. A autora descreveu como diferenças entre $P$. crinita e $P$. lichtensteinii a relação entre o comprimento e largura da carapaça, sendo esta mais longa do que larga para P. crinita e mais larga do que 
longa para $P$. lichtensteinii, porém isso não foi observado, uma vez que a carapaça tende a ser aproximadamente igual ou um pouco mais longa do que larga para ambas as espécies. Diferenças essas que também foram observadas por Torres (1998), analisando material proveniente do Brasil e dos Estados Unidos e sugeriu que $P$. crinita do Brasil não pertencia a essa espécie.

Examinando os exemplares de P. finneganae do MNRJ e do parátipo do MZUSP, constatou-se que esta é um sinônimo de $P$. lichtensteinii. A presença de um tubérculo entre os espinhos laterais e subhepáticos, como mencionado por Rathbun (1937), para separar P. finneganae e P. lichtensteinii, foi um caráter variável, podendo ou não estar presente em espécimes de P. lichtensteinii. Adicionalmente, a presença de um espinho posterior, superior longo para $P$. finneganae foi observado em espécimes com ou sem a presença de um tubérculo entre as margens laterais e subhepáticas. Outro caráter utilizado para a espécie por Rathbun (1933) é região intestinal parcialmente definida por sulcos rasos, mas este caráter também não se manteve constante, estando presente e ou ausente em espécimes de $P$. finneganae e $P$. lichtensteinii.

Os síntipos de P. crinita (USNM 64254), coletados em Horn Island Pass, Mississipi (Estados Unidos) em 30 de Agosto de 1930 e o tipo de P. finneganae (USNM 67989) de São Sebastião (Brasil) em 1933 foram analisados, o que permitiu a confirmação de que realmente os espécimes identificados como $P$. crinita e $P$. finneganae para o Brasil são sinônimos de $P$. lichtensteinii. Os espécimes de $P$. crinita do Atlântico Sul não se encaixam com a descrição original da espécie, nem com as figuras de Rathbun (1931, 1937) e provavelmente a identificação incorreta destes animais tenha ocorrido pela falta de trabalhos taxonômicos para a família Leucosiidae e para o gênero Persephona para espécies do Atlântico Sul. Estando dessa maneira disponíveis em âmbito geral, principalmente os trabalhos de Rathbun (1931, 1933 e 1937) para espécimes de $P$. crinita. Assim, devido a grande variação intraespecífica da 
morfologia dos espinhos de $P$. lichtensteinii e sem o conhecimento de espécimes da América do Norte, muitos pesquisadores inferiram que parte da variação poderia estar associada à outra espécie, $P$. crinita, com a presença de espinhos curtos na margem posterior e tubérculos ou dentes nas margens laterais e subhepáticas.

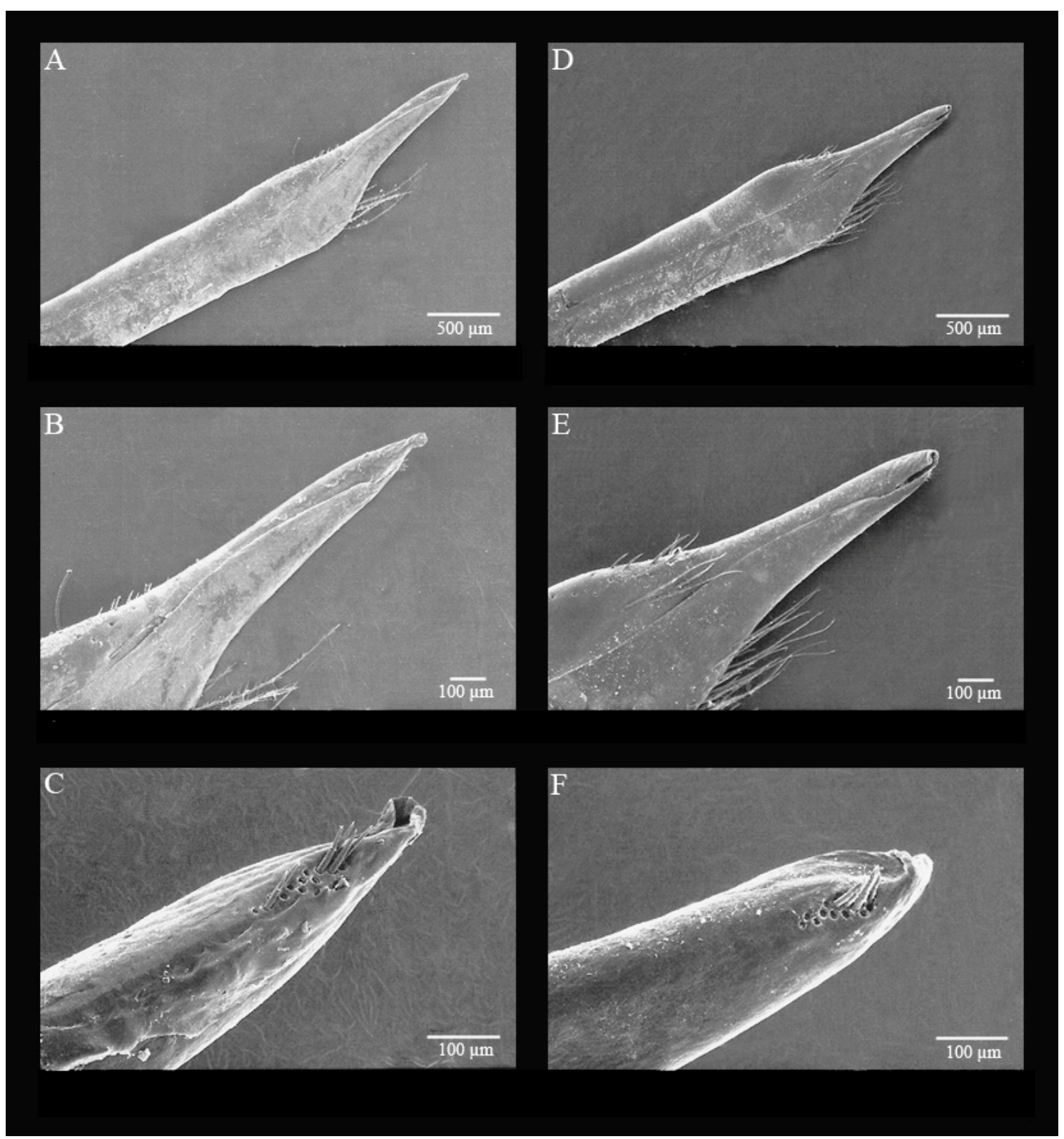

Figura 7. Microscopia Eletrônica de Varredura dos gonópodos (MEV) de Persephona crinita do Golfo do México (ULLZ 1847) (A-35x, B-75x e C-200x) e Persephona lichtensteinii (CCDB 1430) (D-35x, E-75x e F-200x). 


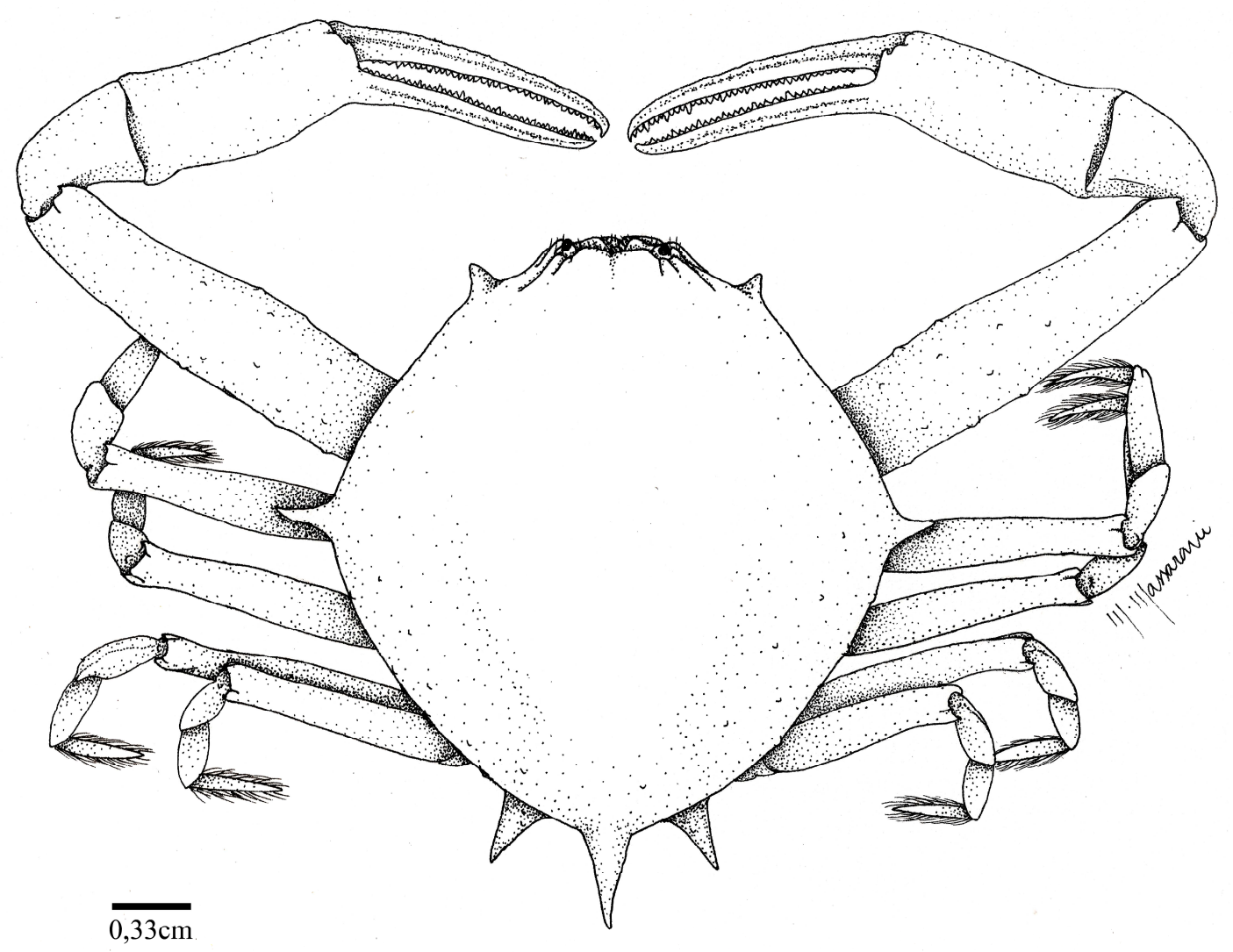

Figura 8. Persephona lichtensteinii Leach, 1817. Vista dorsal. Macho (CCDB 1430), $\mathrm{CC}=23,81 \mathrm{~mm}$.

Persephona mediterranea (Herbst, 1794) (Fig. 13)

Cangrejo Tortuga: - Parra, 1787: 137, lam. 51, fig. 2.

Cancer mediterraneous: Herbst, 1794: 150, tab. 37, fig. 2.

Leucosia mediterranea: - Lichtenstein, 1815: 142.

Guaia punctata: - H. Milne Edwards, 1837: 127; - Lucas, 1840:121; - Gibbes, 1850: 185; - Desbonne, 1867: 53;

Persephona punctata: - Stimpson, 1859: 70; - Miers, 1886: 312, pr. 25, fig. 5.; Hay \& Shore, 1918: 423, pr. 32, fig. 9; - Rodriguez, 1980: 254, lam. 12; - Takeda, 1983: 116, fig. s/n; 
Persephone punctata: - von Marten, 1872: 113; - Kingsley, 1878: 324; - Moreira, 1901: 35; - Luederwaldt, 1919: 435; - Wells et al., 1961: 267;

Persephona punctata aquilonaris: - Rathbun, 1933: 184; 1937: 154, pl. 42, fig. 6,7; - Humes, 1941: 102; - Behre, 1950:23; - Hildebrand, 1954: 276; - Wass, 1955: 154; Holthuis, 1959:183; - Williams, 1965:150, fig. 127; - Walker, 1974:681; - Overstreet \& Heard, 1978:132; - Abreu, 1980:3.

Persephona aquilonaris: - Guinot-Dumortier, 1959: 429 (não P. aquilonaris Rathbun, 1933); - Tabb \& Manning, 1961: 600; - Fausto-Filho, 1968: 44 (não $P$. aquilonaris Rathbun, 1933); - Rouse, 1970: 24, fig. 65; - Coelho \& Ramos, 1972: 183; - Felder, 1973: 42, pr. 5, fig. 4; - William, 1974: 24, fig. 65; - Taissoun, 198688: 132,133; - Ortíz \& Olcha, 2011: 51.

Persephona mediterranea: - Guinot-Dumortier, 1959: 433; - Powers, 1977: 39; Coelho \& Torres, 1980: 72; - Williams, 1984: 288 (não P. mediterranea Herbst, 1794); - Abele \& Kim, 1986: 43, fig. i (não P. mediterranea Herbst, 1794); - Coelho et al., 1986: 100; - Bordin, 1987: 9; - Melo, 1989: 5; - Negreiros-Fransozo et al., 1989: 177; - Raz-Guzman \& Sánchez, 1992: 30, pr. I,1; - Hyodo, 1996: 4, fig. 1; Melo, 1996: 153 (fig. e mapa); - Souza, 1997: 38; - Torres, 1998: 115, fig. 29; Mantelatto \& Fransozo, 2000: 212; - Mantelatto et al., 2003: 211; - Branco \& Fracasso, 2004: 299; - Braga et al., 2005: 3, fig. 9; - Witzell \& Schmid, 2005: 191; Keunecke et al., 2007: 49; Coelho et al., 2008: 15; - Felder \& Camp, 2009: 1075; Martínez et al., 2009: 279; - Bertini et al., 2010: 7; - Carvalho et al., 2010: 109; Teixeira, 2010: 3; - Vieira \& Calazans, 2010: 432; - Hirose et al., 2012: 17.

Persephona punctata punctata: - Lemos de Castro, 1962: 38, est. 1, figs. 3-4 (não P. punctata Linnaeus, 1758).

Localidade-tipo: Aqui designada como Ubatuba, São Paulo, Brasil. 
Material-tipo: Neótipo de P. mediterranea, Ubatuba, SP, Brasil. Coleção de Crustáceos do Departamento de Biologia, FFCLRP-USP Ribeirão Preto, São Paulo (CCDB 3881).

Material analisado: Neótipo (CCDB 3881) Estados Unidos: Texas 01 macho (33,73mmะ0,25) (“ULLZ 1997 2008”); Flórida 01 juvenil (16,61mm) (ULLZ 10158); Brasil: Espírito Santo 01 fêmea (38,45mm) ("MNRJ 23309"); Rio de janeiro, Cabo Frio 01 macho e 01 fêmea $(33,47 \mathrm{~mm} \pm 1,41)$ (MNRJ 3900); Arraial do Cabo 01 juvenil (28,68mm) ("MNRJ 3899"); Rio de Janeiro 04 machos e 04 fêmeas (35,87mm $\pm 2,79)$ ("MNRJ 333334346 712”); Guaratiba 01 macho (36,53mm) ("MNRJ 342"); Angra 03 machos e 03 fêmeas $(35,33 \mathrm{~mm} \pm 3,77)$ (MNRJ 38973898 4462); Ilha Grande 03 machos e 02 fêmeas $(34,03 \mathrm{~mm} \pm 5,86)$ ("MNRJ 4463"); São Paulo, Caraguatatuba 01 macho (31,25mm) (CCDB 758); Ubatuba 10 machos, 06 fêmeas e 04 juvenis (30,83mm5,91) (CCDB 1450153926632836 3881); Santos 02 machos e 01 fêmea $(37,66 \mathrm{~mm} \pm 7,23)$ (“MNRJ 23308”); Santa Catarina, São Francisco do Sul 01 macho (35,10mm) (CEPESUL 113). “" espécimes identificados como P. mediterranea nas etiquetas da ULLZ ou P. p. punctata no MNRJ; entretanto, estas devem modificar a identificação para $P$. aquilonaris e P. mediterranea, respectivamente.

Diagnose: Três espinhos na carapaça presentes na margem posterior. Coloração bege com pigmentação vermelha-castanho; pigmentação na superfície dorsal da carapaça formando duas manchas paralelas na porção ântero-dorsal, delimitadas e definidas com as bordas onduladas; presença de manchas em forma de círculo na região posterior e lateral. Gonópodo (pleópodo 1) com presênça de lobo proeminente no bordo látero-distal. Fronte proeminente.

Redescrição: superfície dorsal da carapaça coberta por grânulos diminutos esparsados, visíveis a olho nu; carapaça, excluindo os espinhos posteriores, tão 
longa quanto larga; formato subglobular. Três espinhos ou dentes na margem posterior, sendo um superior normalmente cilíndrico e dois inferiores mais comprimidos na base no eixo dorso-ventral, com extremidades curvadas para cima; margem subhepática sinuosa, podendo ou não conter um grânulo ou proeminência; presença de uma linha definida de grânulos entre os espinhos posteriores inferiores; presença de uma linha definida de grânulos mais proeminente na porção anterior, diminuindo na porção posterior até a região intestinal, dividindo a região dorsal a ventral. Fronte proeminente, aproximadamente 2,5 vezes mais larga do que longa; bipartida com um " $\mathrm{v}$ " na porção mediana. Meropodito do terceiro maxilípodo com granulação esparsa; isqueopodito com aproximadamente 2/3 internos liso; coxopodito com granulação na porção distal; exopodito e basepodito com granulação esparsa. Quelípodos delgados, mero totalmente coberto por grânulos, que diminuem de tamanho da parte proximal para a distal; própodo aproximadamente 3 vezes mais longo do que largo; presença de pequenos dentes entre os dedos móvel e fixo; presença de carenas ao longo de ambos os dedos. Patas ambulatórias sem grânulos; ausência de linha de cerdas na margem dorsal do própodo; presença de carenas e cerdas no dáctilo; dáctilo com formato espatuliforme. Esternitos praticamente lisos; episternitos com grânulos diminutos na ligação com os esternitos. Gonópodo (pleópodo 1) longo; bordo lateral e mesial estreitos; porção distal estreita com presença de cerdas longas e proeminentes; presença de um lobo proeminente no bordo látero-distal; ausência de ornamentação; sutura marginal na face ventral; abertura distal. Coloração bege com manchas vermelhas-castanho, marrons ou laranjas; duas manchas medianas da região anterior até final da região intestinal, definidas e delimitadas com as bordas laterais onduladas, separadas por ausência de pigmentação; presença de círculos menores nas regiões ântero-lateral, lateral, postero-lateral e às vezes posterior; presença de manchas menores em círculos nos quelípodos. 
Distribuição: Atlântico Ocidental - Antilhas, Venezuela, Suriname, Guiana Francesa e Brasil (do Amapá ao Rio Grande do Sul), e Uruguai.

Observações: Guinot-Dumortier (1959) analisando fotos do material tipo de Cancer mediterraneous (Herbst, 1794) (Fig. 9), o qual apresenta localização errônea (Mar Mediterrâneo), sugeriu pela primeira vez que este espécime era muito semelhante a P. aquilonaris (Rathbun, 1933) (Fig. 3) e os espécimes do continente americano deveriam ser nominados Persephona mediterranea. No entanto, ao examinar espécimes provenientes dos Estados Unidos, identificados como $P$. aquilonaris, verificou-se que o padrão de coloração desta é bastante distinto dos espécimes encontrados na América do Sul; P. aquilonaris apresenta um padrão de coloração também marrom avermelhado, porém com manchas pequenas esparsas distribuídas por toda a superfície da carapaça, sendo mais concentrada no centro e se espaçando para as bordas (Fig. 3). Enquanto em $P$. mediterranea as manchas são mais densas e maiores, sendo normalmente duas grandes longitudinalmente e outras um pouco menores (semicirculares) espalhadas nas laterais e região posterior (Fig. 13). Além disso, a morfologia do gonópodo de ambas as espécies foi um caráter que se manteve constante em cada espécie, permitindo a sepração entre elas.

O gonópodo de $P$. aquilonaris apresenta abertura distal larga, direcionada qusase inteiramente para a face mesial ventral e não apresenta lobo proeminente na bordo látero-distal, (Figs. 12, A, B e C). Enquanto o gonópodo de $P$. mediterranea apresenta abertura mais estreita do que em $P$. aquilonaris e praticamente distal e um lobo bastante proeminente no bordo látero-distal (Fig. 12 D, E e F). Assim, padrão de coloração e morfologia dos gonópodos podem ser utilizados como caracteres para separação de ambas. No entanto, outros caracteres como espinho, grânulos, fronte, quelípodos, proporções de tamanhos dos artículos, entre outros, mostraram-se constantes entre as duas, não permitindo clara separação de ambas a partir destes. 
Ao analisar o material-tipo da espécie P. aquilonaris (USNM 62057) cuja localidade-tipo é Sta Augustine, Flórida, concluiu-se que os espécimes do Atlântico Norte e Golfo do México correspondem a P. aquilonaris (Rathbun), enquanto os espécimes analisados do Atlântico Sul correspondem a $P$. mediterrânea, baseando-se na cor e morfologia do gonópodo. Assim, a figura representada no trabalho de Guinot-Dumortier (1959) corresponde a $P$. mediterranea e não a $P$. aquilonaris. Além dos caracteres ditos como variáveis, a presença de grânulo na margem subhepática é um carater bastante variável, podendo ou não estar presente em adultos ou juvenis de ambas as espécies.

Parra citou pela primeira vez, em 1787, a ocorrência de Cangrejo Tortuga proveniente de Cuba (Fig. 10), o qual corresponde a P. mediterranea; no entanto este não foi utilizado para representar a espécie, mas sim Cancer mediterraneous de Herbst, 1794 (Fig. 10), que descreveu o espécime, segundo ele, proveniente do Mar Mediterrâneo, a partir do qual provavelmente colocou o nome na espécie. No entanto sabe-se que nenhuma espécie do gênero ocorre no Mediterrâneo, sendo, portanto desconhecida à localidade-tipo da espécie. Assim, selecionou-se um Neótipo de P. mediterranea proveniente de Ubatuba, SP, Brasil, depositado na CCDB sob o número 3881 para designar a localidadetipo da espécie, uma vez que os espécimes provenientes dessa localidade correspondem a P. mediterranea de Herbst (1794) como verificado na literatura e nas análises morfológicas e ocorrer amplamente em Ubatuba.

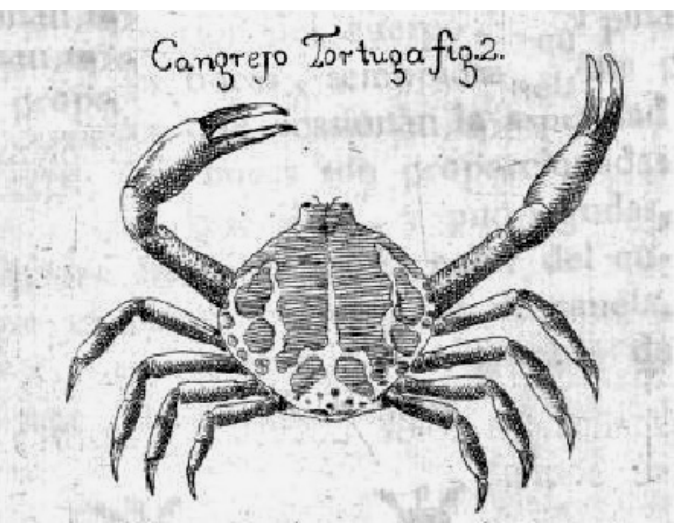

Figura 9. Cangrejo Tortuga Parra, 1787. Desenho extraído de Parra (1787). 


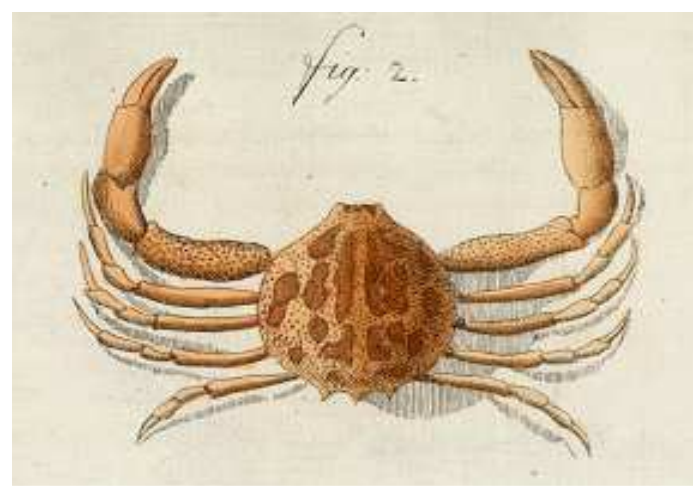

Figura 10. Cancer mediterraneus Herbst, 1794. Desenho extraído de Herbst (1794).

Posteriormente às análises, um espécime com padrão semelhante a ${ }^{*} P$. mediterranea, foi identificado a partir de imagem, porém com ocorrência no Sul da Flórida, coletado pelo Dr. Gordon Atkins, postado do site: http://www.biol.andrews.edu/everglades/organisms/invertebrates/arthropods/purse_crab /purse_crab.html; porém este apresenta a superfície da carapaça mais clara e manchas laranja claro (Fig. 11), ao invés de marrons ou vermelhas castanho. No entanto, análises morfológicas e moleculares devem ser realizadas com espécimes provenientes dessa região, no intuito de compreender o padrão de distribuição de P. mediterranea.

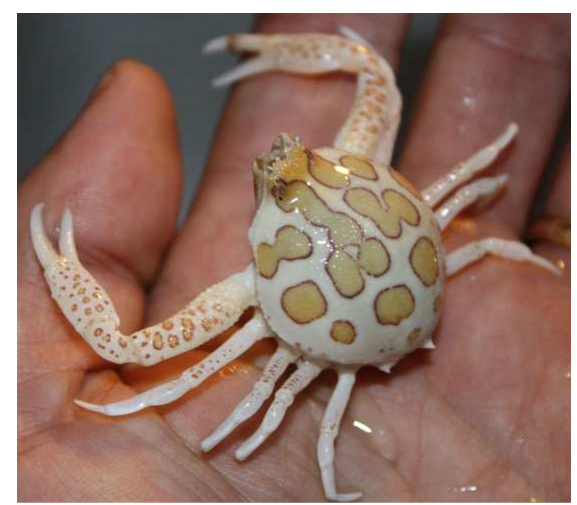

Figura 11. Exemplar de ${ }^{*} P$. mediterranea coletado no Sul da Flórida (EUA). 


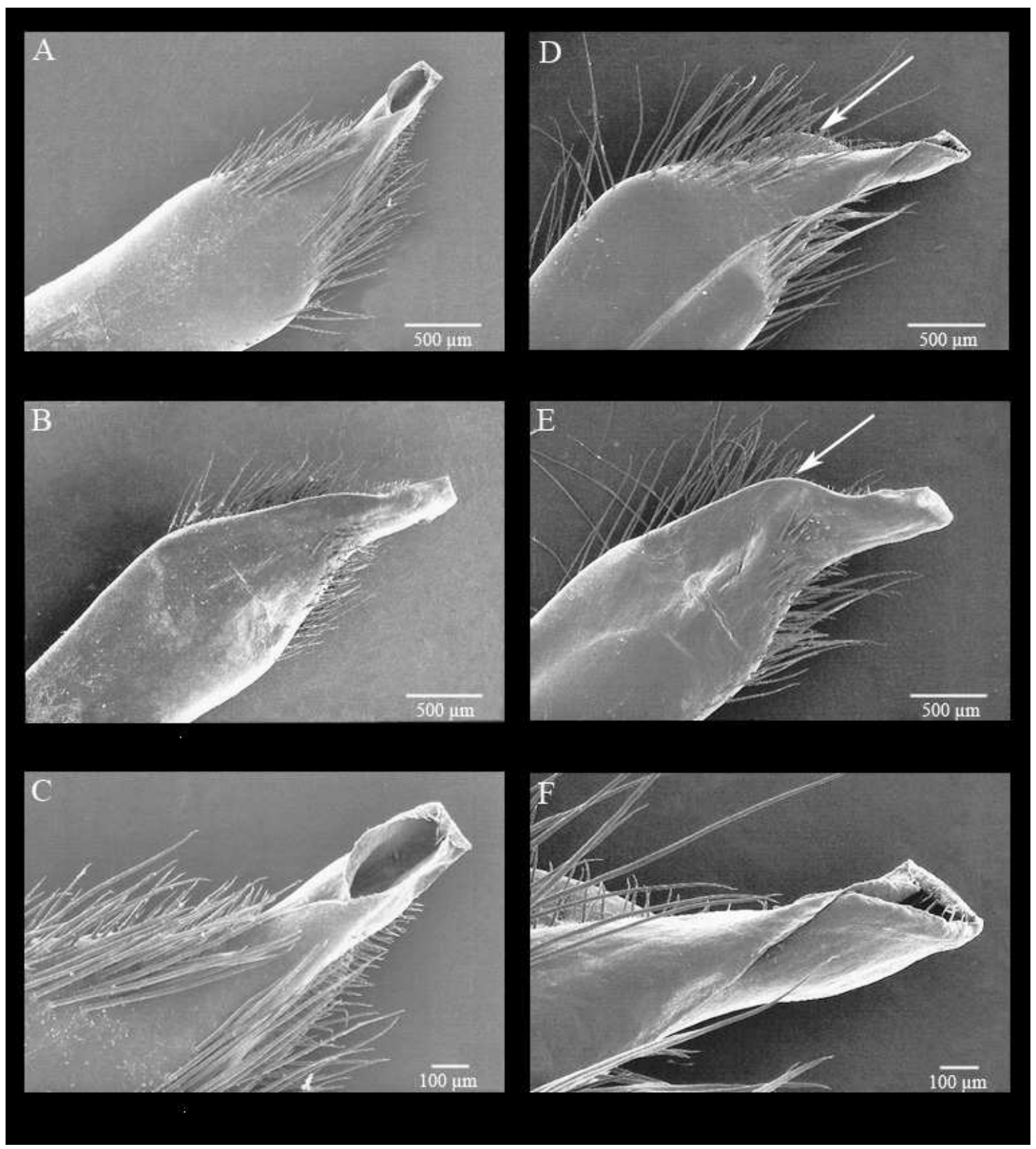

Figura 12. Microscopia Eletrônica de Varredura (MEV) dos gonópodos de Persephona aquilonaris (ULLZ (ULLZ 9407) (A-35x, B-35x e C-100x) e Persephona mediterranea (CCDB 3881) (D-35x, E35x e F-200x), setas indicando lobo proeminente no bordo latero-distal. 


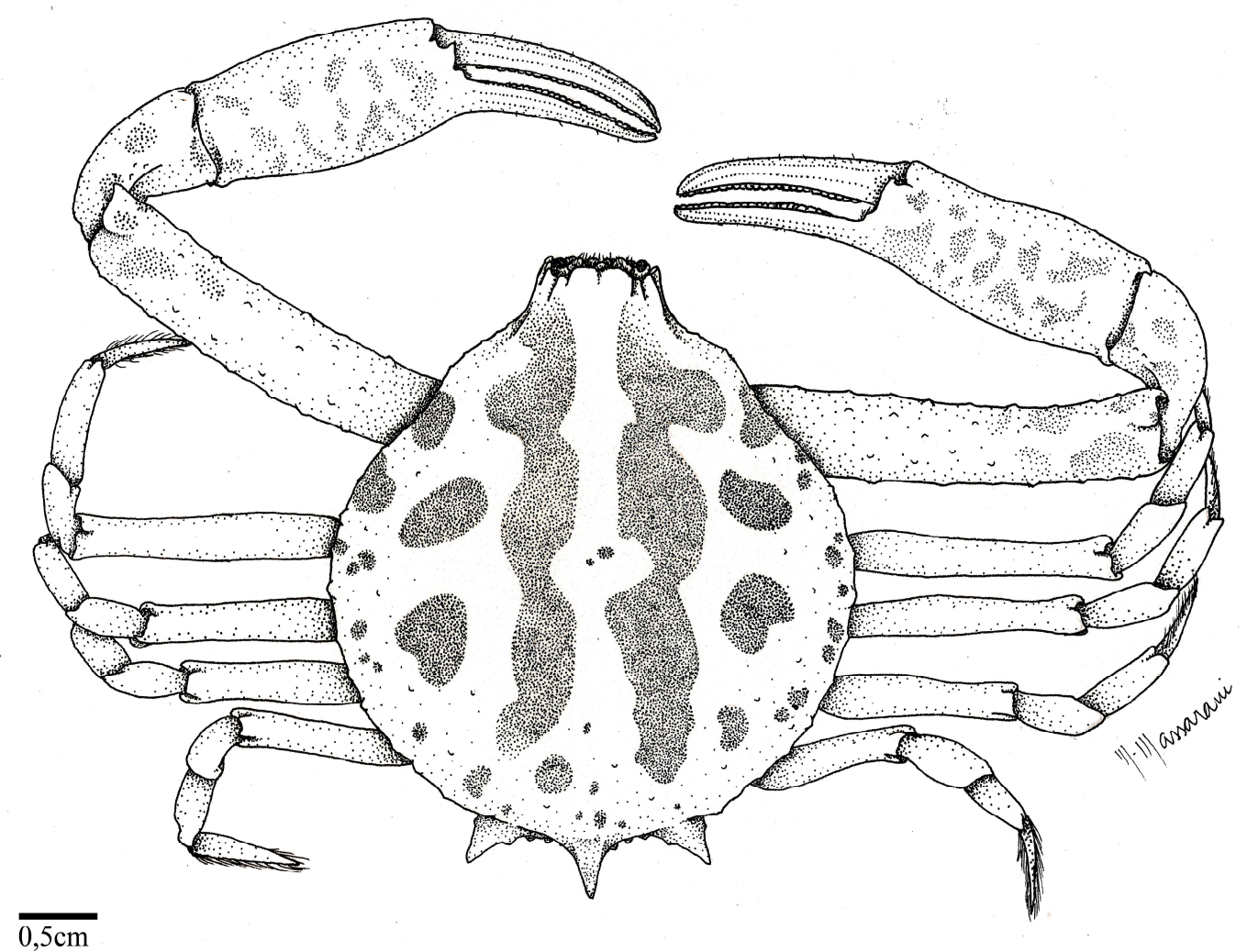

Figura 13. Persephona mediterranea (Herbst, 1794). Vista dorsal. Macho (CCDB 3881), $\mathrm{CC}=33,58 \mathrm{~mm}$.

Persephona orbicularis Bell, 1855 (Fig. 14)

Persephona orbicularis: Bell, 1855: 294; - Rathbun, 1937: 160, pl. 45, figs. 5-6; Wehrtmann \& Echeverría-Sáenz, 2007: 124; - Vargas-Castilho, 2008: 108.

Localidade-tipo: Valparaiso, Chile.

Material-tipo: 01 fêmea de P. orbicularis. Museu Britânico. Não analisado.

Material analisado: Costa Rica: 03 machos, 01 fêmea e 01 juvenil $(30,06 \mathrm{~mm} \pm 4,48)$ (CCDB 2939); Panamá: 01 juvenil (24,08mm) (ULLZ 10078).

Diagnose: Cinco espinhos na carapaça, três na margem posterior, dois espinhos curtos na margem subhepática. 
Redescrição: superfície da carapaça esparsamente granulada; grânulos visíveis a olho nu; carapaça, excluindo os espinhos posteriores, tão longa quanto larga. Presença de cinco espinhos ao redor da carapaça, três posteriores e dois espinhos ou dentes na margem subhepática; espinho posterior superior longo e cilíndrico, pequena curvatura para cima; espinhos inferiores curtos e cilíndricos; presença de uma fileira de grânulos não bem delimitada entre os dois espinhos inferiores. Fronte pouco pronunciada, aproximadamente 3,5 vezes mais larga do que longa. Carapaça ovóide, mais larga no meio e estreita-se nas extremidades; regiões da carapaça pouco delimitadas. Isqueopodito do terceiro maxilípodo com duas fileiras de grânulos ao longo da margem externa que sobem até o meropodito; meropodito com grânulos distribuídos na sua porção distal; presença de cerdas em ambos os artículos; exopodito e coxopodito com granulação esparsa. Quelípodo com mero constrito próximo ao carpo; proeminente granulação na parte proximal, principalmente superfície dorsal, reduzindo na porção distal; presença de pequenos e poucos grânulos na margem interna e externa do carpo e própodo; presença de cerdas e dentes irregulares entre os dedos; própodo aproximadamente 4,5 vezes mais longo do que largo; dedos delgados com presença de carena; presença de hiato variável. Patas ambulatórias sem grânulos, com presença de linha de cerdas na margem dorsal do própodo e superfície dorsal e ventral do dáctilo; própodo com compressão na margem dorsal; dáctilo com formato espatuliforme. Gonópodo (pleópodo 1) longo; bordo lateral e mesial estreitos; porção distal estreita com presença de cerdas longas e proeminentes na borda lateral proximal à distal; presença de fileira de cerdas curtas na borda mesial; ausência de lobo proeminente no bordo látero-distal; ausência de ornamentação; sutura marginal na face ventral; presença de tufo de cerdas subapicais na face dorsal; abertura distal estreita, apical. 
Distribuição: Pacífico Oriental - Ilhas Perlas, Costa Rica até Chile.

Observações: A partir das análises dos espécimes de $P$. orbicularis provenientes da Costa Rica e P. townsendi proveniente do México, foi verificado que existem caracteres variáveis entre os espécimes de ambas as espécies, não permitindo uma separação dos exemplares. Além disso, a morfologia do gonópodo foi um caráter que se manteve constante e igual para exemplares das duas espécies. No entanto, uma ampla discussão é realizada nas observações de $P$. townsendi.

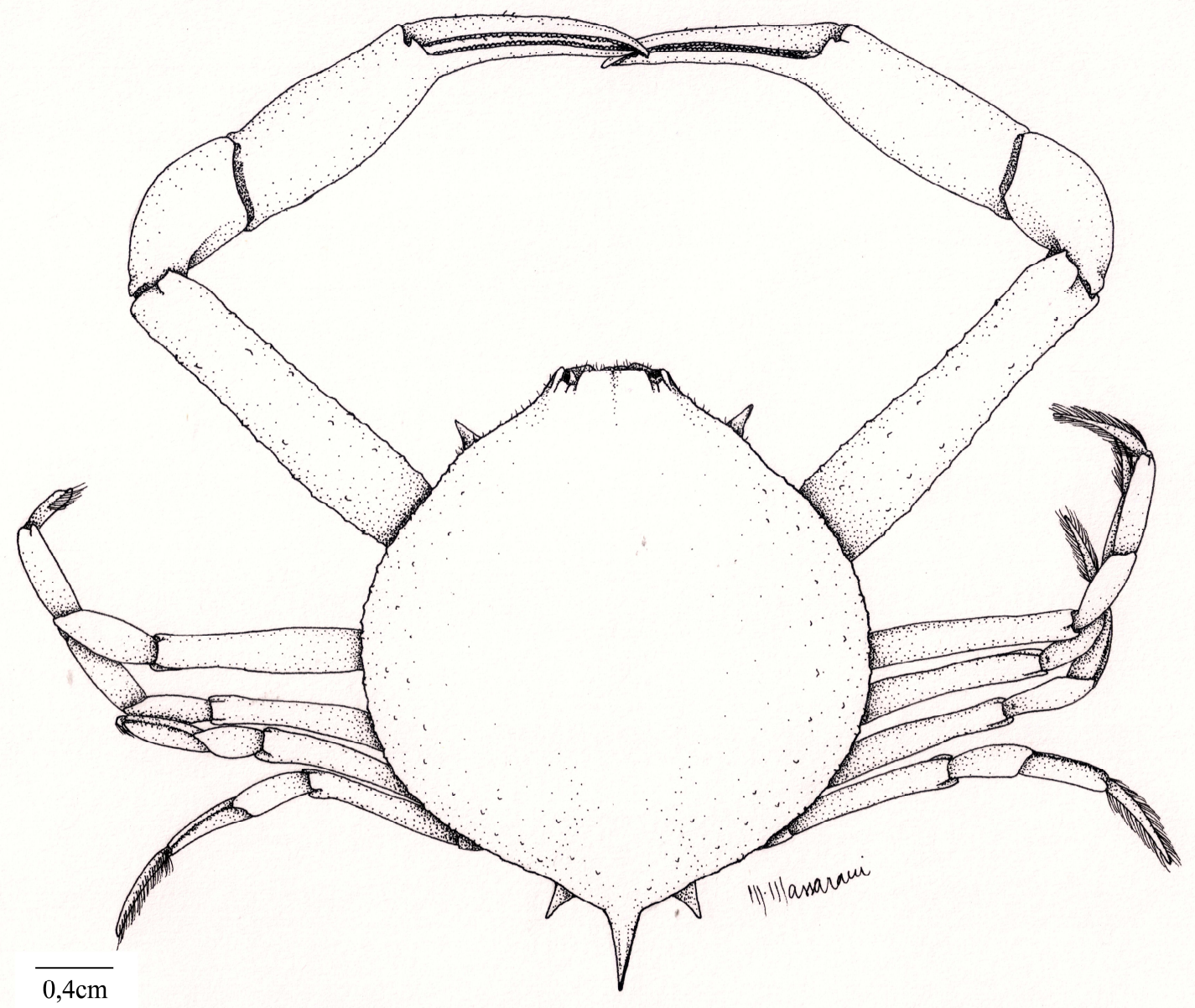

Figura 14. Persephona orbicularis Bell, 1855. Vista dorsal. Macho (CCDB 2940), $\mathrm{CC}=34,98 \mathrm{~mm}$.

Persephona punctata (Linnaeus, 1758) (Fig. 15)

Cancer punctatus: - Browne, 1756: 422, pr. 42, fig. 3; Linnaeus, 1758: 630.

Persephona latreilli: - Leach, 1817: 22. 
Persephona lamarckii: - Leach, 1817: 23.

Guaia punctata: - H. Milne Edwards, 1837: 127; - Gibbes, 1850: 185; - Desbonne, 1867: 53 .

Persephona guaia: - Bell, 1855: 292.

Persephona punctata: - Stimpson, 1859: 70; - Rathbun, 1897: 38; 1901: 87; 1933: 98, fig. 94; - Hay \& Shore, 1918: 423, pr. 32, fig. 9; - Boone, 1930: 54, pr. 10, fig. B; - Guinot-Dumortier, 1959: 428, figs. 5 a,b, 6; - Holthuis, 1959: 183; - Fausto-Filho, 1966: 33; - Coelho \& Ramos, 1972: 183; - Gomes-Corrêa \& Silva-Brum, 1980: 61; Rodriguez, 1980: 254, lam. 12; - Coelho et al., 1983: 154; 1986: 100; - Coelho \& Ramos-Porto, 1986: 73; - Taissoun, 1986-88: 130, 131 (fig.); - Bordin, 1987: 9; Melo, 1989: 5; - Werding \& Müller, 1989: 410; - Hyodo, 1996: 4, fig. 1; - Melo, 1996: 154 (fig e mapa); - Torres, 1998: 126, fig. 31; - Mantelatto \& Fransozo, 2000: 212; - Severino-Rodrigues, 2002: 177; - Branco \& Fracasso, 2004: 299; - Braga et al., 2005: 3, fig. 9; - Martínez et al., 2009: 279; - Carvalho et al., 2010: 109; Teixeira, 2010: 3; - Hirose et al., 2012: 17.

Persephone punctata: - Luederwaldt, 1919: 435 (erro).

Persephona punctata punctata: - Rathbun, 1937: 152, pl. 42, figs. 2-3; Rodrigues da Costa, 1968: 334; - Donovan et al., 2003: 3; - Collins et al., 2009a: 28 e b: 65.

Persephona mediterranea: - Martínez-Iglesias \& Gómez, 1986: 11, fig. 6a (não P. mediterranea Herbst, 1794).

Localidade-tipo: Jamaica

Material-tipo: Lectótipo de P. punctata. Não analisado.

Material analisado: Suriname: Saramacca 01 macho e 01 fêmea $(34,82 \mathrm{~mm} \pm 3,94)$ (USNM 103479); Brasil: Pará 01 fêmea (27,08mm) (“MNRJ 348”); Ceará,

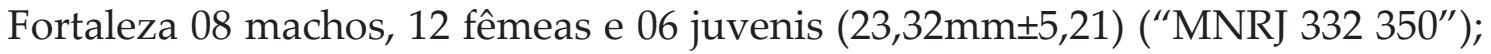
Bahia, Itacaré 02 machos, 04 fêmeas e 04 juvenis $(28,20 \mathrm{~mm} \pm 5,45)$ (MNRJ 2460); 
Cumuruxatiba 01 macho (30,57mm) (MNRJ 14424); Espírito Santo, Linhares 01 macho e 01 fêmea $(34,23 \mathrm{~mm} \pm 4,24)$ ("MNRJ 339"); Guarapari 06 machos e 06 fêmeas $(29,83 \mathrm{~mm} \pm 4,08)$ (MNRJ 4464 4465); Anchieta 01 macho, 02 fêmeas e 01 juvenil (28,25mm4,35); Rio de Janeiro, São Francisco de Itabapoana 01 fêmea e 01 juvenil $(26,52 \mathrm{~mm} \pm 7,07)$ (“MNRJ 344" 13754); Rio de Janeiro 01 juvenil (23,44mm) ("MNRJ 347"); São Paulo, Ubatuba 08 machos e 05 fêmeas $(33,24 \mathrm{~mm} \pm 4,16)($ CCDB 002200272529283728382856 3049); Caraguatatuba 01 fêmea e 03 juvenis $(20,83 \mathrm{~mm} \pm 9,72)$ (CCDB 0755 1532); São Vicente 01 macho $(39,78 \mathrm{~mm})$ ("MNRJ 335”); Santos 03 machos e 01 fêmea $(34,25 \mathrm{~mm} \pm 4,03)$ ("MNRJ $\left.331343^{\prime \prime}\right)$.

“” espécimes identificados como P. p. punctata nas etiquetas das instituições visitadas; entretanto, estas devem modificar a identificação para P. punctata.

Diagnose: Três espinhos e dois dentes na carapaça; três espinhos na margem posterior e dois dentes ou grânulos na margem subhepática. Fronte pouco pronunciada.

Redescrição: superfície dorsal da carapaça coberta por grânulos diminutos espaçados, visíveis a olho nu; carapaça, excluindo os espinhos posteriores, tão longa quanto larga; formato subglobular. Três espinhos ou dentes na margem posterior, sendo um superior normalmente cilíndrico e dois inferiores mais comprimidos na base no eixo dorso-ventral; margem subhepática angulosa e proeminente; presença de um grânulo ou dente; presença de uma linha definida de grânulos entre os espinhos posteriores inferiores; presença de uma linha definida de grânulos mais proeminente na porção anterior, diminuindo na porção posterior até a região intestinal, dividindo a região dorsal a ventral, sem extremidade curvada para cima. Fronte pouco proeminente, aproximadamente 5 vezes mais larga do que longa; bipartida, com um " $v$ " na porção mediana. 
Isqueopodito do terceiro maxilípodo com forte granulação da parte interna, diminuindo na parte externa; presença de cerdas e grânulos pequenos; exopodito com granulação esparsa; coxopodito com grânulos maiores e cerdas na base; grânulos menores na parte distal. Quelípodos delgados, mero totalmente coberto por grânulos, que diminuem de tamanho da porção proximal para a distal; pequenos e poucos grânulos na parte externa do própodo; presença de cerdas entre cada segmento; própodo aproximadamente 3 vezes mais longo do que largo; presença de dentes de tamanho uniforme entres os dedos movél e fixo; presença de carenas ao longo de ambos os dedos. Patas ambulatórias sem grânulos; ausência de linha de cerdas na margem dorsal do própodo; presença de carenas e cerdas no dáctilo; dáctilo com formato espatuliforme; pode ocorrer a presença de tufos de cerdas aderidos aos pereiópodos e quelípodos. Esternitos praticamente lisos; episternitos com grânulos diminutos na ligação com os esternitos. Gonópodo (pleópodo 1) longo; bordo lateral e mesial estreitos; porção distal estreita com presença de cerdas longas e proeminentes na borda lateral e mesial; presença cerdas na face ventral e um linha de cerdas na face dorsal até próximo do bordo apical; extremidade distal alargada; ausência de lobo proeminente no bordo látero-distal; ausência de ornamentação; sutura marginal na face ventral; ausência de tufo de cerdas subapicais; abertura distal bastante larga e apical. Coloração arroxeada ou vinho, uniformemente na superfície dorsal da carapaça.

Distribuição: Atlântico Ocidental - Antilhas, Colômbia, Venezuela, Guianas e Brasil (Amapá ao Rio Grande do Sul).

Observações: Persephona punctata (Linnaeus, 1758) foi considerada por muito tempo como sendo indistinta de P. aquilonaris e P. mediterranea. Rathbun (1937) em uma revisão sobre $P$. punctata, verificou que os espécimes dos Estados Unidos eram distintos dos espécimes das Antilhas e da América do Sul, 
havendo apenas uma pequena área de sobreposição de ambas. Assim, a autora criou dois novos taxa, Persephona punctata aquilonaris e Persephona punctata punctata, sendo a última uma subespécie de P. punctata, e de distribuição no Sul, diferenciando ambas em sua chave de identificação, pelo tamanho da fronte, sendo levemente pronunciada em $P . p$. punctata e proeminente em $P . p$. aquilonaris. No entanto, Guinot-Dumortier (1959) enquanto examinava espécimes de Persephona provenientes da coleção do Muséum Nationale d'Histoire Naturelle, verificou quem ambas eram bastante distintas, devendo ser consideradas entidades taxonômicas distintas e não subespécies. A autora observou que P. punctata ocorria do Panamá, Antilhas, Guiana Francesa e Brasil (até Santa Catarina), enquanto P. aquilonaris teria ocorrência nos Estados Unidos (Nova Jersey, Flórida, Texas), Antilhas, Guiana Francesa e Brasil (até Rio Grande do Sul). Sendo essas espécies erroneamente consideradas subespécies por Rathbun (1937), devendo ser consideradas P. aquilonaris e P. punctata.

É possível distinguir claramente $P$. punctata e $P$. mediterranea, seja pelo tamanho da fronte, aproximadamente 5 e 2,5 vezes mais larga do que longa, respectivamente, morfologia do gonópodo ou coloração. P. punctata apresenta coloração arroxeada e praticamente uniforme na superfície dorsal, tornando-se mais clara da borda da carapaça, não apresentam padrão de mancha. O ângulo entre a fronte e a margem subhepática é menor, sempre com a presença de um grânulo ou dente nessa margem. Além disso, a morfologia dos gonópodos é completamente distinta (Fig. 18, E e G).

A localidade-tipo da espécie foi inicialmente determinada por Linnaeus como Ásia e América, porém Fabricius (1798) diferenciou os espécimes da Ásia e América identificando-os como Leucosia fugax e Leucosia punctata, respectivamente. Browne (1756) representou um espécime de Cancer punctatus proveniente da Jamaica e como ainda não havia uma localidade-tipo para a espécie, Holthuis (1959) selecionou o lectótipo de Cancer punctatus a partir do 
espécime representado por Browne e a localidade-tipo da espécie passou a ser Jamaica.

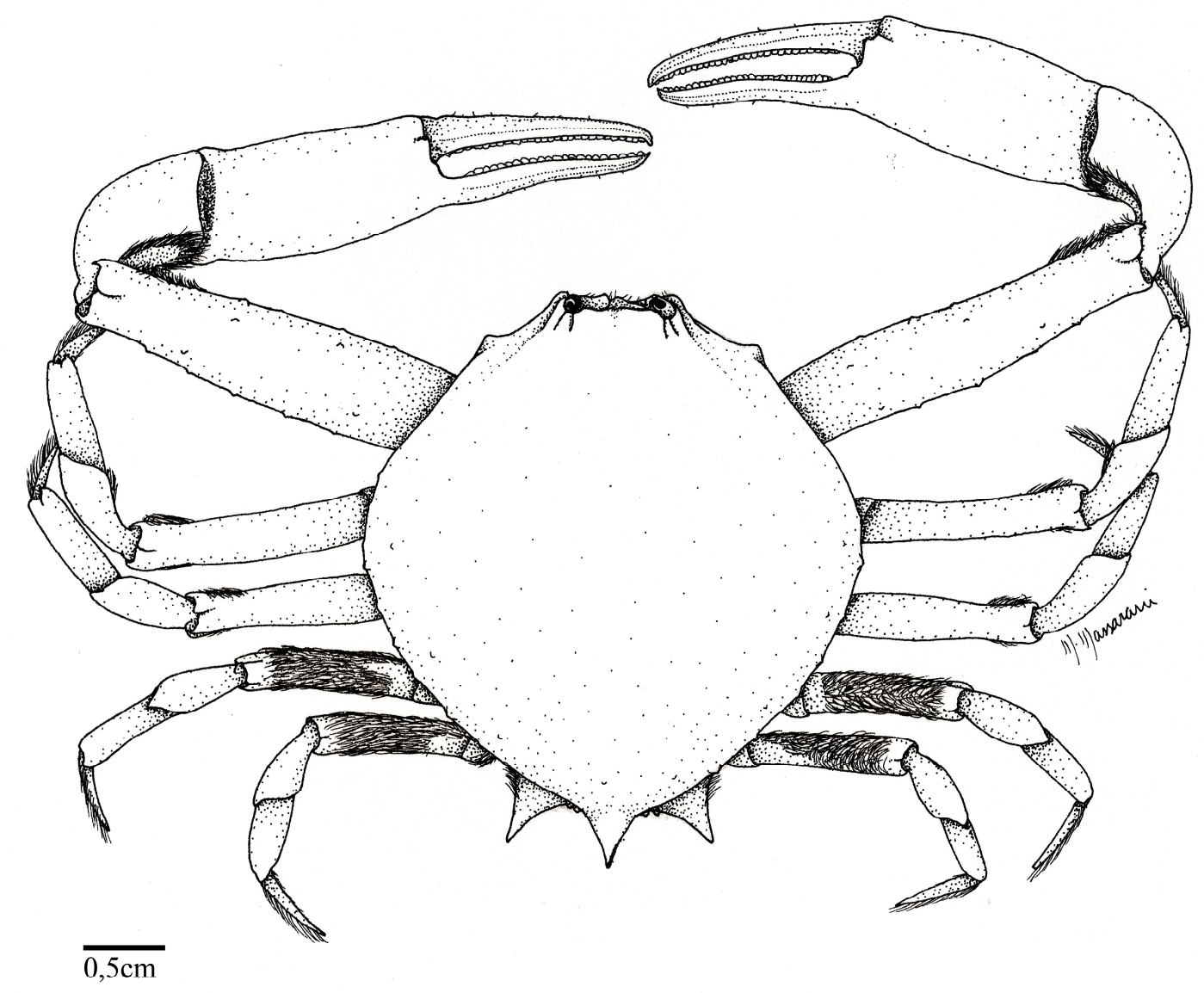

Figura 15. Persephona punctata (Linnaeus, 1758). Vista dorsal. Macho (CCDB 2856), CC=36,64mm.

Persephona subovata (Rathbun, 1894) (Fig. 16)

Myra subovata: Rathbun, 1893: 256.

Persephona subovata: - Rathbun, 1898: 613; - Rathbun, 1937: 158, pl. 43, figs. 45; Hendrickx, 1995: 129; 1997: 149.

Persephona edwardsii: - Boone, 1930: 53, pl. 10, fig. A (não P. edwardsii Bell, 1855). 
Localidade-tipo: Isla Tiburón, Sonora.

Material-tipo: Holótipo 01 macho (juvenil) e 01 fêmea de Myra subovata. National Museum of Natural History (Smithsonian Institution), Washington DC, (USNM 17385). Analisado.

Material examinado: Holótipo de P. subovata (USNM 17385) e holótipo de $I$. hancocki (USNM 69260). México: Sonora, 01 fêmea e 01 macho (juvenil) $(18,10 \mathrm{~mm} \pm 6,09)(\mathrm{USNM} 17385) ;$ Oaxaca, 02 machos e 01 fêmea $(29,82 \mathrm{~mm} \pm 4,75)$ (CNCR 3269); Costa Rica: 01 macho 02 fêmeas (27,33mm³,24) (“CCDB 1644 $\left.2834^{\prime \prime}\right)$.

“" espécimes identificados como I. hancocki na CCDB. No entanto, esta deve modificar a identificação para P. subovata.

Diagnose: Três espinhos na carapaça na margem posterior. Quelípodos longos, própodo aproximadamente 6 vezes mais longo do que largo. Fronte proeminente.

Redescrição: superfície dorsal da carapaça coberta por grânulos diminutos espaçados, pouco visíveis a olho nu; carapaça, excluindo os espinhos posteriores, tão longa quanto larga; formato subglobular; fileira de grânulos separando a região dorsal e ventral. Três espinhos na margem posterior; superior longo e cilíndrico; posteriores longos e cônicos. Margem subhepática sinuosa; ausência de grânulo ou dente. Fronte proeminente, aproximadamente 1,5 vezes mais larga do que longa; fortemente bipartida devido às depressões laterais; presença de um " $\mathrm{v}$ " na porção mediana. Terceiro maxilípodo com presença de uma fileira de grânulos que parte da porção proximal até a distal do isqueopodito; meropodito côncavo com grânulos diminutos na margem 
externa; exopodito com poucos grânulos na porção distal. Quelípodos bastante longos; presença de poucos e pequenos grânulos; ausência de cerdas nos artículos; própodo aproximadamente 6 vezes mais longo do que largo; presença de dentes de tamanho uniforme entres os dedos movél e fixo; presença de carenas ao longo de ambos os dedos. Patas ambulatórias sem grânulos; ausência de linha de cerdas na margem dorsal do própodo; presença de carenas e cerdas no dáctilo; dáctilo com formato espatuliforme. Regiões da carapaça mal definidas. Gonópodo (pleópodo 1) longo; bordo lateral e mesial estreitos; porção distal estreita, curvada com presença de cerdas longas e proeminentes ao longo da borda mesial; ausência de lobo proeminente no bordo látero-distal; ausência de ornamentação; sutura marginal na face ventral; presença de tufo de cerdas subapicais na face dorsal; abertura distal bastante estreita e apical.

Observações: Os espécimes de $P$. subovata analisados foram bastante realizada semelhantes aos espécimes de I. hancocki (Rathbun, 1935). Observação também por Hendrickx (1997), em que o autor sugere a análise do material tipo dessas espécies, no intuito de checar o status taxonômico de ambas. Em análises dos materiais provenientes da Costa Rica e do Panamá de I. hancocki, juntamente com o material tipo de ambas as espécies no USNM, foi possível observar que não existem caracteres morfológicos que se mantenham constantes em cada espécie. A taxa de grânulos na periferia da carapaça, distância entre os espinhos posteriores (relacionado ao crescimento, como discutido para $P$. lichtensteinii) e a presença de um grânulo na margem subhepática foi descrito por Rathbun (1935) para I. hancocki, porém não foi possível detectar diferença entre os espécimes de $I$. hancocki e $P$. subovata, indicando que estas não são espécies distintas. Para a sinonímia foi utilizada a lei de prioridade, em que o nome válido de um táxon é o nome disponível mais antigo aplicado a ele. Dessa 
maneira, como P. subovata é um nome mais antigo disponível, é sugerido que $I$. hancocki seja sinônimo júnior de $P$. subovata.

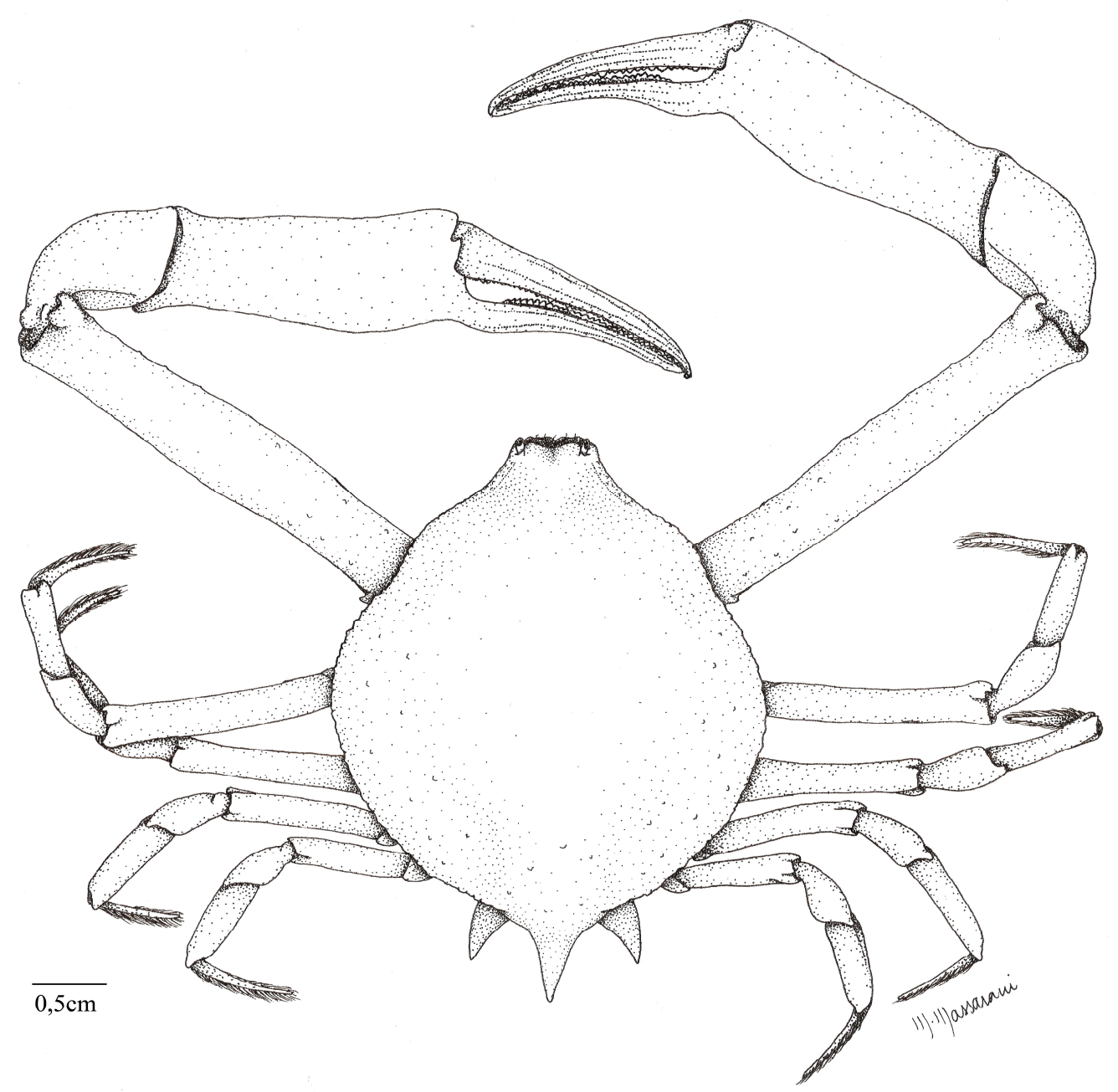

Figura 16. Persephona subovata (Rathbun, 1894). Vista dorsal. Macho (CNCR 3269), $C C=34,56 \mathrm{~mm}$.

Persephona townsendi (Rathbun, 1894) (Fig. 17)

Myra townsendi: Rathbun, 1893: 255.

Persephona townsendi: - Rathbun, 1898: 613; 1910: 594; 1937: 160, pr. 42, fig. 1, pr. 43, fig. 1; - Garth, 1948: 18; 1960: 121; 1966: 9; - Buitendijk, 1950: 271; - Paul \& 
Hendrickx, 1980: 10; - Rodríguez de la Cruz, 1987: 119; - Correa-Sandoval, 1991: 13; - Lemaitre \& Alvarez-León, 1991: 51; - Hendrickx, 1993: 8; 1995: 129; 1996: 616; - Hendrickx, 1997: 150, fig. 106.

Localidade-tipo: Baixa Califórnia, México.

Material-tipo: Holótipo 01 macho de Myra townsendi. National Museum of Natural History (Smithsonian Institution), Washington DC, (USNM 17382). Analisado.

Material examinado: Holótipo (USMN 17382). México: Baixa California 01 macho (31,79mm) (USNM 17382); Sinaloa 01 fêmea (32,02mm) (CCDB 3025); Panamá: 02 juvenis $(18,53 \mathrm{~mm} \pm 6,80)$ (ULLZ 13931).

Diagnose: Cinco espinhos na carapaça, três na margem posterior, dois espinhos longos na margem subhepática.

Redescrição: superfície da carapaça esparsamente granulada; grânulos visíveis a olho nu; carapaça, excluindo os espinhos posteriores, tão longa quanto larga. Presença de cinco espinhos ao redor da carapaça, três posteriores e dois espinhos longos na margem subhepática; espinho posterior superior longo e cilíndrico, pequena curvatura para cima; espinhos inferiores curtos e cilíndricos; presença de uma fileira de grânulos não bem delimitada entre os dois espinhos inferiores; espinhos na margem subhepática curtos e agudos. Fronte pouco pronunciada, aproximadamente 2,5 vezes mais larga do que longa; pouco granulada na porção anterior. Carapaça ovóide, mais larga no meio e estreita-se nas extremidades; regiões da carapaça pouco delimitadas. Isqueopodito do terceiro maxilípodo com duas fileiras de grânulos ao longo da margem externa 
que sobem até o meropodito; meropodito com grânulos distribuídos na sua porção distal; presença de cerdas em ambos os artículos; exopodito e coxopodito com granulação esparsa. Quelípodo com mero constrito próximo ao carpo; proeminente granulação na parte proximal, principalmente superfície dorsal, reduzindo na porção distal; presença de pequenos e poucos grânulos na margem interna e externa do carpo e própodo; presença de cerdas e dentes irregulares entre os dedos; própodo aproximadamente 4 vezes mais longo do que largo; dedos delgados com presença de carena; presença de hiato variável. Patas ambulatórias sem grânulos, com presença de linha de cerdas na margem dorsal do própodo e superfície dorsal e ventral do dáctilo; própodo com forte compressão na margem dorsal; dáctilo com formato espatuliforme. Gonópodo (pleópodo 1) longo; bordo lateral e mesial estreitos; porção distal estreita com presença de cerdas longas e proeminentes na borda lateral proximal à distal; presença de fileira de cerdas curtas na borda mesial; ausência de lobo proeminente no bordo látero-distal; ausência de ornamentação; sutura marginal na face ventral; presença de tufo de cerdas subapicais na face dorsal; abertura distal estreita, apical.

Distribuição: Pacífico - Golfo da Califórnia, México até Paita, Perú.

Observações: A partir da análise dos espécimes de $P$. orbicularis e $P$. townsendi, observou-se grande semelhança morfológica entre ambas. O número de espinhos, tamanho dos espinhos na margem subhepática, assim como tamanho dos espinhos posteriores não se mantiveram constantes em cada uma, havendo variação em ambas as espécies. Rathbun (1937) em sua chave de identificação distingue ambas as espécies pela forma e tamanho dos espinhos da margem subhepática, sendo longos e agudos em $P$. townsendi e curtos e dentiformes em P. orbicularis. No entanto, assim como discutido anteriormente, tamanho e 
forma dos espinhos, são bastante variáveis, tendo em vista que esses animais possuem o hábito de se enterrarem, o que pode promover a quebra e o desgaste desses espinhos. Além disso, a partir da MEV (Fig. 18) constatou-se que os gonópodos de ambas são bastante semelhantes, podendo indicar que são a mesma espécie, uma vez que esse caráter dentro do gênero Persephona é informativo e distinto, sendo possível utilizá-lo para separação de espécies. Assim, a distinção entre $P$. orbicularis e $P$. townsendi realizada por Rathbun (1937), pode estar equivocada.

No entanto, o acesso a um número restrito de espécimes do gênero provenientes do Pacífico, dificultou a análise de variabilidade dos caracteres. Apesar do material tipo de P. townsendi ter sido analisado no National Museum of Natural History (Smithsonian Institution), Washington DC, (USNM 17382), o material tipo de $P$. orbicularis não foi analisado, o qual segundo Bell, 1855 encontra-se no British Museum. Assim, sugere-se que um número maior de espécimes de ambas as espécies sejam analisados quanto a morfologia e aspectos moleculares, assim como o material tipo de ambas, no intuito de checar o status taxonômico dessas espécies. 


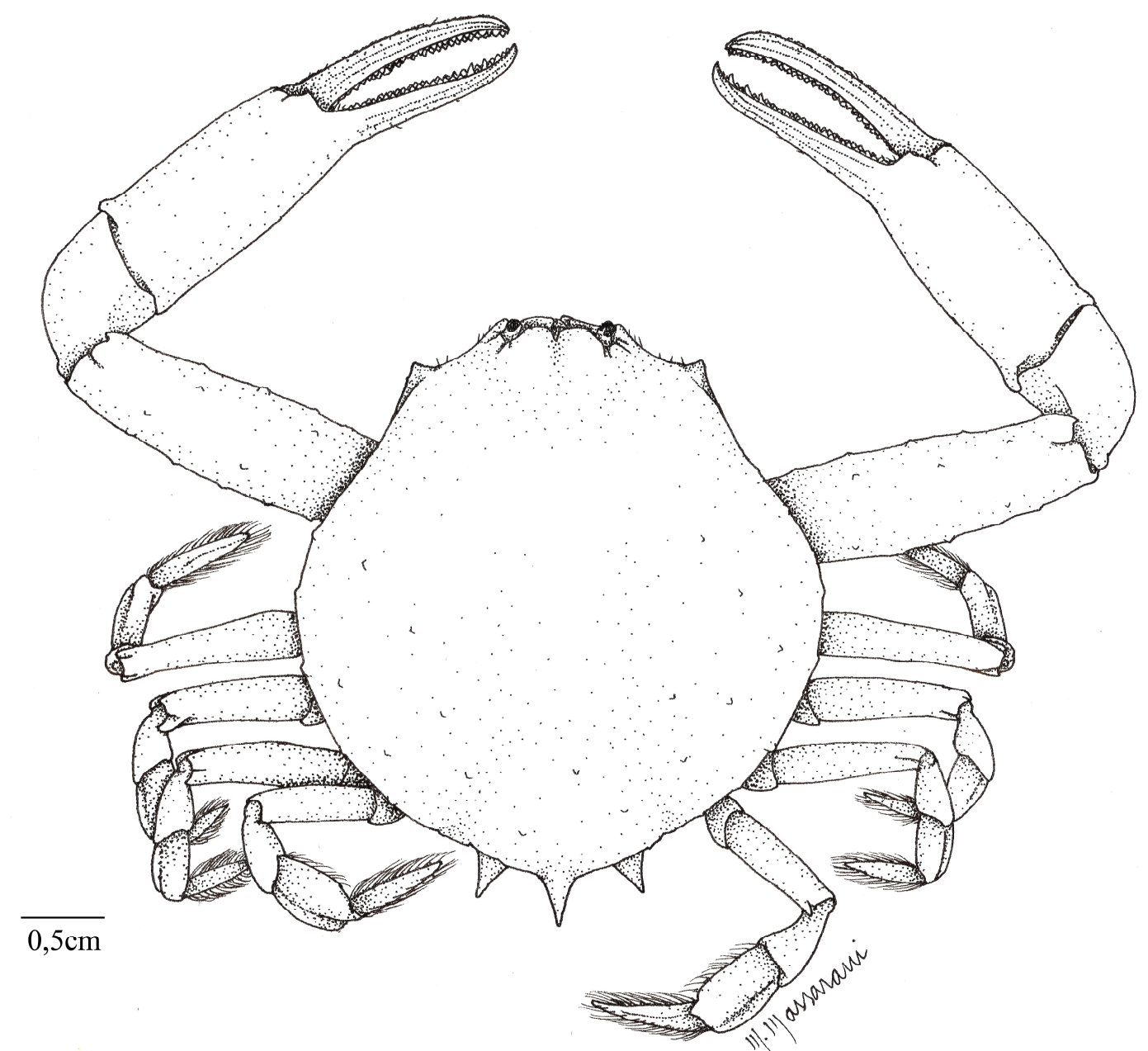

Figura 17. Persephona townsendi (Rathbun, 1893). Vista dorsal. Fêmea (CCDB 3025), $C C=32,02 \mathrm{~mm}$.

Análise comparativa dos gonópodos

A partir da análise morfológica dos gonópodos das espécies de Persephona (Fig. 18), constatou-se que existem diferenças morfológicas que podem ser utilizadas como um caráter informativo nas análises comparativas. A descrição de cada gonópodo foi detalhada na redescrição da espécie, incluindo imagens em diferentes aumentos no intuito de ilustrar essa diferenciação capaz de separar as espécies do gênero. As estruturas foram coladas nos strubs na mesma posição. 


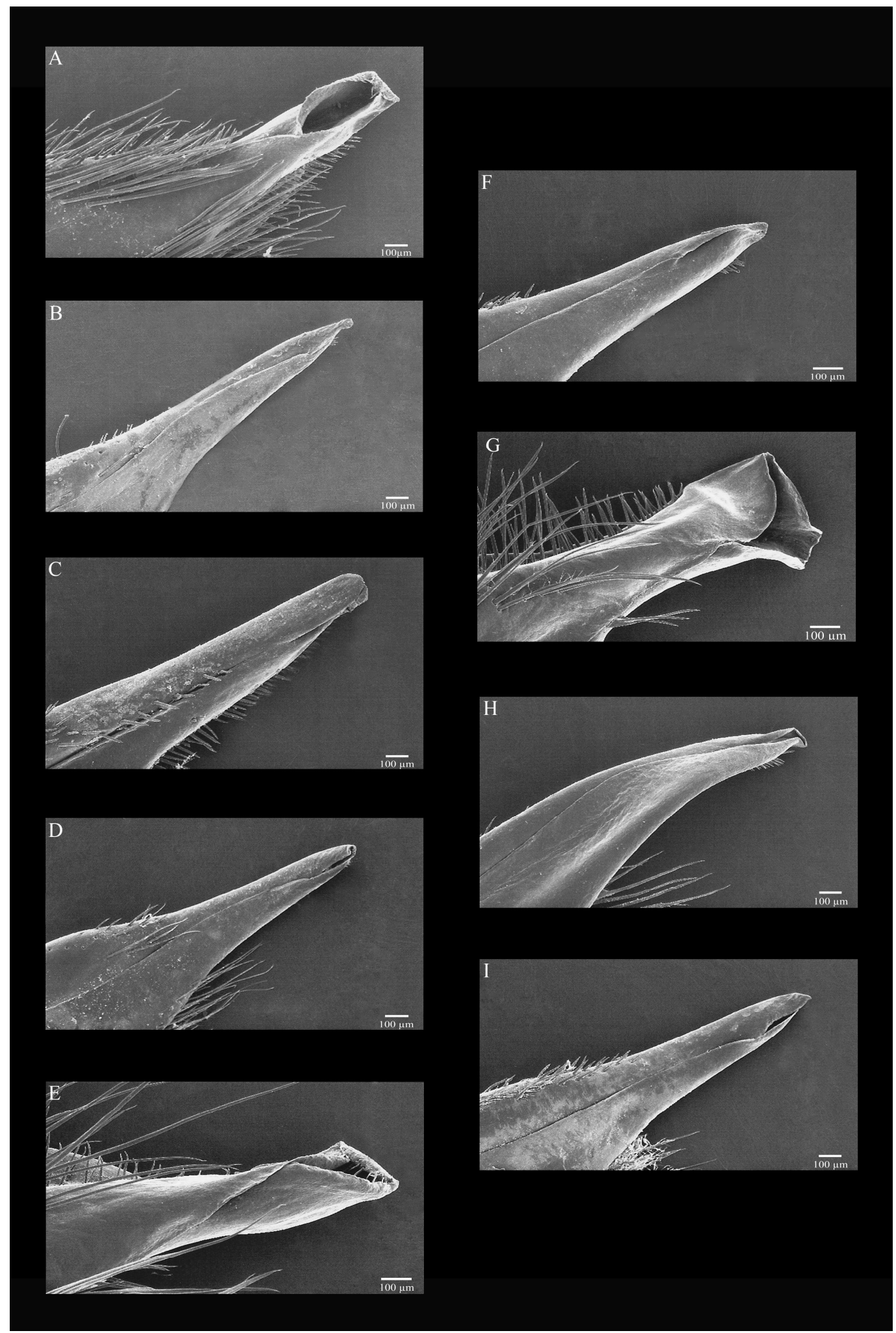

Figura 18. Microscopia Eletrônica de Varredura (MEV) dos gonópodos das espécies de Persephona: A - P. aquilonaris (aumento de 75x) (ULLZ 9407); B - P. crinita do Golfo do México (aumento de 75x) (ULLZ 1847); C - P. edwardsii (aumento de 75x) (CNCR 18997); D - P. lichtensteinii (aumento de 75x) (CCDB 1430); E - P. mediterranea (aumento de 100x) (CCDB 3881); F - P. orbicularis (aumento de 100x) (CCDB 2940); G - P. punctata (aumento de 100x) (CCDB 1539); H - P. subovata (aumento de 75x) (CNCR 3269); I - P. townsendi (aumento de 75x) (CCDB 3025). 


\subsection{Análises Moleculares}

Para as análises moleculares foram utilizados 19 espécimes do Atlântico Ocidental e 4 do Pacífico Oriental de diferentes localidades (Golfo do México Estados Unidos e México; Mar do Caribe - Colômbia, Honduras e Venezuela; Atlântico Sul: Brasil - AL, BA, ES, SP e SC). Adicionalmente foi utilizada uma sequência do Genbank de um espécime da África (Ebalia nux) para enraizamento da árvore, juntamente com sequências de Acanthilia intermedia, Goniopsis cruentata, Iliacantha intermedia e Iliacantha subglobosa. A escolha de Ebalia nux como grupo externo, apesar da distinta distribuição de Persephona, foi devido a não existência de muitas sequências disponíveis no Genbank para membros da família Leucosiidae.

Os espécimes identificados com aspas ("'”) indicam que os nomes provenientes das etiquetas originais dos lotes depositados nas instituições carcinológicas podem estar assinalados de forma equivocada. Baseando-se nas análises morfológicas, sugere-se que: "P. crinita" e "P. finneganae" podem corresponder a $P$. lichtensteinii e "P. mediterranea" pode corresponder a $P$. aquilonaris.

O alinhamento total das sequências consistiu de 606 pares de bases para o gene COI e 485 pares de base para o gene 16S, excluindo-se os primers.

\section{Análises de distância}

As análises de distâncias foram realizadas no intuito de dar maior robustez aos resultados morfológcos, baseando-se nas distâncias genéticas entre sequências dos genes COI e $16 \mathrm{~S}$ para as espécies de Persephona, como mostrado nas tabelas III e IV, provendo outra fonte de informação distinta da morfologia, dando maior embasamento as mudanças propostas no estudo. 
Gene mitocondrial Citocromo Oxidase I (COI)

Para a análise de distância foram utilizados 21 espécimes de Persephona, provenientes de 13 localidades diferentes.

- Atlântico: quatro do Golfo do México (EUA: Texas e Louisiana), três do Mar do Caribe (Honduras, Colômbia e Venezuela) e dez do Atlântico Sul (Brasil: Alagoas, Bahia, Espírito Santo, São Paulo e Santa Catarina); Pacífico: uma de México: Oaxaca, uma de Costa Rica e duas do Panamá. Foram também incluindo dois espécimes de Iliacantha provenientes da Flórida (EUA) e Costa Rica (Tab. IV).

Para ambos os genes (COI e 16S), a análise de substituições mostrou uma tendência de não saturação dos dados (Fig. 19), ou seja, não havendo diminuição da infomação filogenética contida nas sequências.

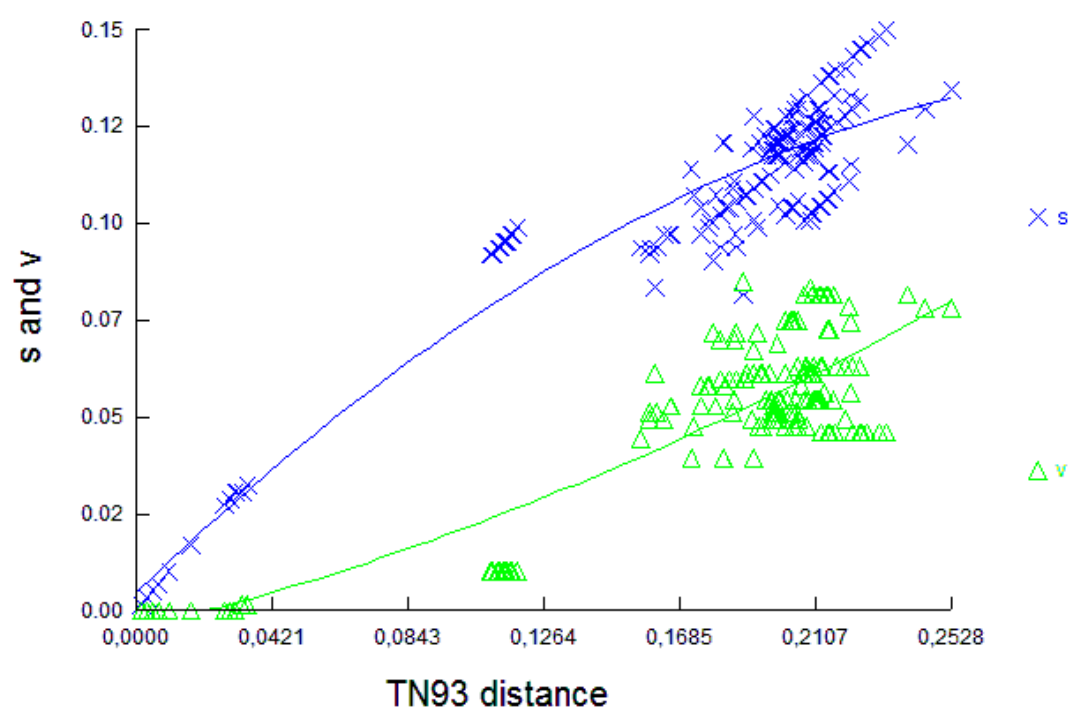

Figura 19. Teste de saturação do gene Citocromo Oxydase I (COI). Gráfico de transição (s) e transvesão (v) versus distância de Tamura e Nei.

O teste G1 para verificação do sinal filogenético para as sequências de COI indicou que não existe perda de sinal para este gene, uma vez que o escore da árvore mais parcimoniosa encontra-se fora da curva de distribuição dos 
valores obtidos, a partir de permutação ao acaso da matriz de dados. Este resultado também foi observado para o gene $16 \mathrm{~S}$.

A distância genética interespecífica para o gênero Persephona variou de 0\% ("P. finneganae"_ES_Brasil e $P$. lichtensteinii_BA_Brasil) a $18,8 \%$ ( $P$. lichtensteinii_Honduras e "P. mediterranea"_TX_EUA) entre as espécies do Atlântico Ocidental e de 1,7\% (P. orbicularis_Costa Rica e P. townsendi_Panamá) a 18,3\% (P. edwardsii_Panamá e $P$. townsendi_Panamá) entre as espécies do Pacífico Oriental. Já a variação intraespecífica foi de $0,2 \%$ (" $P$. crinita"_AL_Brasil e "P. crinita"_BA_Brasil) a 10,2\% (P. crinita_LA_EUA a "P. crinita"_BA_Brasil) e de $0 \% \quad(P$. lichtensteinii_BA_Brasil e $P$. lichtensteinii_SC_Brasil) a 2,6\% (P. lichtensteinii_Colômbia e $P$. lichtensteinii_SP_Brasil).

Observou-se que as distâncias genéticas entre as espécies " $P$. crinita" (Brasil), "P. finneganae" e P. lichtensteinii, sugeridas como sinônimas baseada nas análises morfológicas, estão dentro do mesmo nível intraespecífico para o gene COI. Entre os espécimes sulamericanos de "P. crinita" e P. lichtensteinii, houve variação de 0,2 a 0,7\% e entre os espécimes de $P$. lichtensteinii e " $P$. finneganae" essa variação foi de 0 a 0,3\%. No entanto, quando comparados espécimes de " $P$. crinita" do Atlântico Sul e P. crinita do Golfo do México (Mississipi, localidadetipo da espécie) a divergência genética observada foi de cerca de $10 \%$, o que indica variação em nível interespecífico, corroborando as análises morfológicas de que os espécimes de "P. crinita" do Atlântico Sul não correspondem a $P$. crinita, mas sim a P. lichtensteinii. Portanto, apenas os espécimes do Golfo do México são corretamente identificados por P. crinita. O mesmo foi observado para " $P$. finneganae", em que a divergência intraespecífica encontrada entre " $P$. finneganae" e P. lichtensteinii corrobora a morfologia observada nos espécimes analisados, indicando que "P. finneganae" seja sinonímia de P. lichtensteinii. Padrão semelhante foi observado por Silva et al. (2011) para as espécies 
Pachygrapsus maurus e Pachygrapsus marmoratus utilizando o gene COI, em que os autores encontraram uma divergência interespecífica baixa, de 0.065\%, indicando não diferenciação entre ambas. Resultado que auxilou na questão taxonômica do grupo.

Na análise entre os espécimes do Caribe e Atlântico Sul, considerando apenas $P$. lichtensteinii como espécie válida, existe uma divergência genética de aproximadamente 3\%, o que poderia indicar uma variação populacional entre o grupo do Caribe e do Atlântico Sul, uma vez que a variação média interna do gênero é cerca de $18 \%$. Além disso, os resultados da análise de distância estão de acordo com a análise morfológica, visto que para estas, não se observou caracteres que se mantivessem constantes em cada espécie, suficientes para a separação dos dois grupos em espécies distintas.

A mesma variação genética de 3\% foi observada para os espécimes de " $P$. mediterranea" do Golfo do México e P. mediterranea do Atlântico Sul. O que poderia indicar uma variação populacional entre espécimes das duas localidades. No entanto, a partir da análise morfológica desses espécimes e de outros analisados (incluindo o tipo de P. aquilonaris), observou-se caracteres que se mantiveram constantes ao longo das análises, como padrão de coloração e morfologia do gonópodo. Assim, essa variação genética poderia indicar não uma variação intraespecífica, mas sim interespecífica capaz de separar as espécies $P$. aquilonaris e $P$. mediterranea, considerando-as como entidades taxonomicamente válidas.

A mesma relação de divergência populacional poderia ser considerada para as espécies do Pacífico, P. orbicularis e $P$. townsendi, as quais apresentam uma divergência de 1,7\%, enquanto a variação interespecífica foi de 18\%. Esse resultado corroboraria as análises morfológicas, nas quais não foram observados caracteres que se mantivessem constantes em cada espécies, indicando que, provavelmente, $P$. townsendi seja sinônimo júnior de $P$. 
orbicularis. No entanto, assim com discutido na morfologia, sugere-se que haja um aumento do número de espécimes analisados na morfologia e na molecular, bem como estudos populacionais e biogeográficos para estas e outras espécies com indícios de variação intraespecífica.

Baseado no gene COI, resultados semelhantes foram observados por Rossi (2012), em que a autora verificou uma variação interespecífica de 6 a 16\% e intraespecífica de 0 a 4\% para algumas espécies de Macrobrachium, utilizando também distância $\mathrm{p}$. 


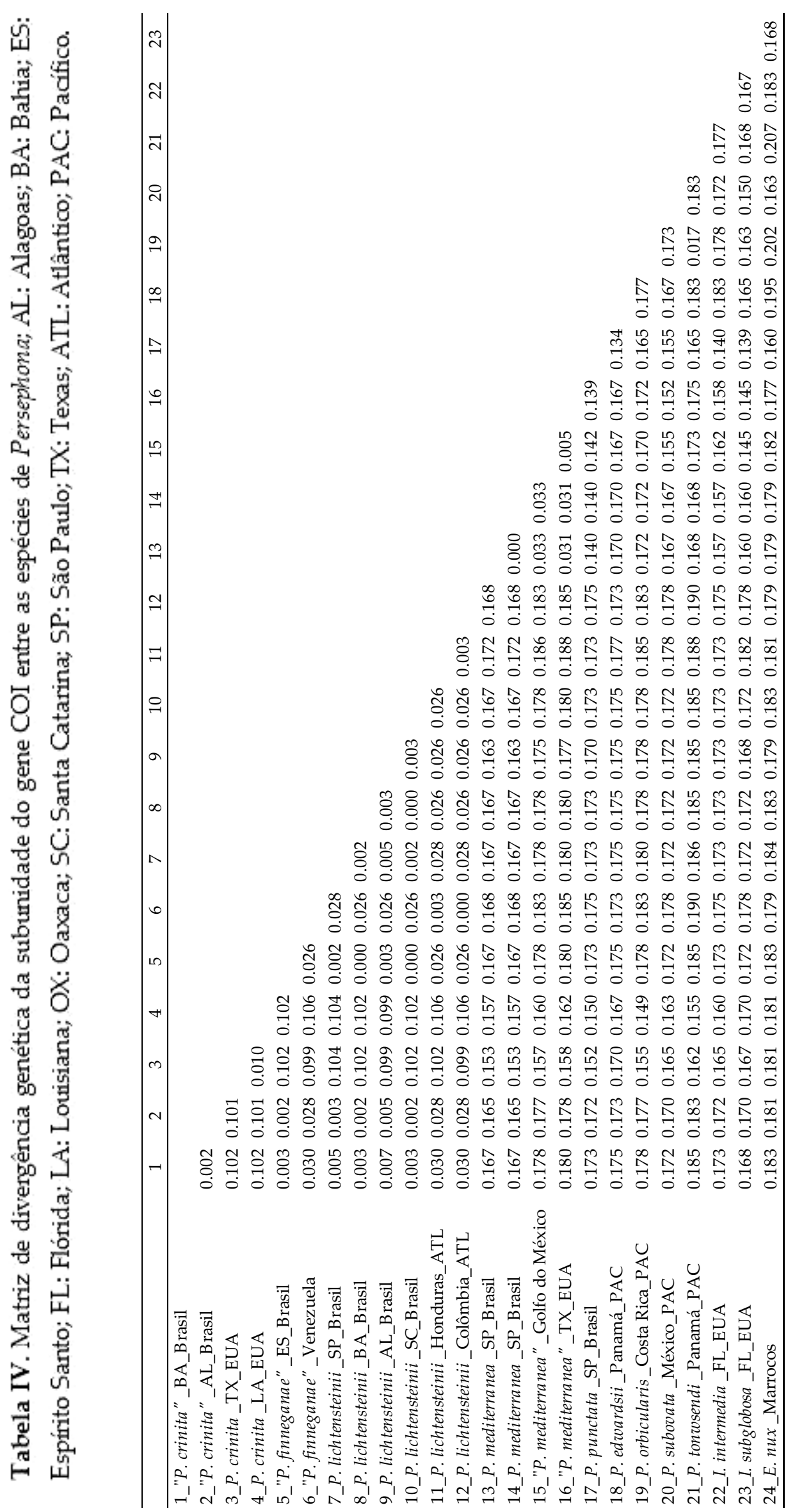


Gene mitocondrial $16 S$

Para o gene 16S foram utilizados 13 espécimes de Persephona, provenientes de 10 localidades diferentes.

- Atlântico: três do Golfo do México (EUA: Texas e Louisiana), três do Mar do Caribe (Honduras, Colômbia e Venezuela) e cinco do Atlântico Sul (Brasil: Bahia e São Paulo); Pacífico: uma de México: Oaxaca, uma de Costa Rica e duas do Panamá. Foram também incluidos dois espécimes de Iliacantha e um de Acanthilia, provenientes dos EUA - Flórida (Tab. V).

Ao analisar as distâncias genéticas baseadas no gene 16S (Tab. V), verificou-se uma variação intraespecífica de $0 \%$ ( $P$. lichtensteinii_SP_Brasil e $P$. lichtensteinii_SP_Brasil) a $\quad 0,4 \% \quad(P . \quad$ lichtensteinii_Honduras $\quad$ e $\quad P$. lichtensteinii_Colômbia) enquanto a variação interespecífica foi de $0 \%$ (" $P$. crinita"_BA_Brasil e P. lichtensteinii_SP_Brasil) a 5,9\% (P. townsendi_Panamá e P. lichtensteinii_SP_Brasil). Assim como para o gene COI, P. crinita do Atlântico Sul está no nível intraespecífico de $P$. lichtensteinii, dado que a varição observada foi de 0\%. Quando comparados espécimes de P. crinita do Atlântico Sul e Golfo do México (TX e LA), a variação de 3,2\% pode ser considerada em nível interespecífico, o que sugere que "P. crinita" do Atlântico Sul seja sinonímia de P. lichtensteinii. O mesmo cenário pôde ser observado em relação a "P. finneganae" para os dois genes analisados, em que a variação de 0 a $0,4 \%$ entre os espécimes de "P. finneganae" e P. lichtensteinii do Caribe e Brasil, indica variação genética em nível intraespecífico. Isso, juntamente com as análises morfológicas permite inferir que "P. finneganae" seja sinonímia de $P$. lichtensteinii A variação genética entre os espécimes de "P. mediterranea" do Golfo do México e P. mediterranea do Atlântico Sul, foi de 1\%. Assim como discutido para a análise do gene COI, esse resultado pode indicar uma variação intraespecífica entre espécimes das duas localidades. No entanto, a partir das análises morfológicas, observou-se que a morfologia dos gonópodos e padrão 
de coloração dos dois grupos são distintos, aumentando a probabilidade de uma variação em nível interespecífico.

Tabela V. Matriz de divergência genética da subunidade do gene $16 \mathrm{~S}$ entre as espécies de Persephona; BA: Bahia; FL: Flórida; LA: Louisiana; SP: São Paulo; TX: Texas; ATL: Atlântico; PAC: Pacífico.

\begin{tabular}{|c|c|c|c|c|c|c|c|c|c|c|c|c|c|c|}
\hline & 1 & 2 & 2 & 3 & 4 & 5 & 6 & 7 & 8 & 10 & 11 & 12 & 13 & 14 \\
\hline \multicolumn{15}{|l|}{ 1_"P.crinita"_BA_Brasil } \\
\hline 2_P.crinita_TX_EUA & 0.032 & & & & & & & & & & & & & \\
\hline 3_P.crinita_LA_EUA & 0.032 & 0.000 & & & & & & & & & & & & \\
\hline 4_"P.finneganae"_Venezuela & 0.002 & 0.029 & 0.029 & & & & & & & & & & & \\
\hline 5_P.lichtensteinii_SP_Brasil & 0.000 & 0.032 & 0.032 & 0.002 & & & & & & & & & & \\
\hline 6_P.lichtensteinii_SP_Brasil & 0.000 & 0.032 & 0.032 & 0.002 & 0.000 & & & & & & & & & \\
\hline 7_P.lichtensteinii_Honduras_ATL & 0.006 & 0.029 & 0.029 & 0.004 & 0.006 & 0.006 & & & & & & & & \\
\hline 8_P.lichtensteinii_Colômbia_ATL & 0.002 & 0.029 & 0.029 & 0.000 & 0.002 & 0.002 & 0.004 & & & & & & & \\
\hline 9_P.mediterranea_SP_Brasil & 0.057 & 0.050 & 0.050 & 0.055 & 0.057 & 0.057 & 0.050 & 0.055 & & & & & & \\
\hline 10_"P.mediterranea"_TX_EUA & 0.059 & 0.048 & 0.048 & 0.057 & 0.059 & 0.059 & 0.053 & 0.057 & 0.010 & & & & & \\
\hline 11_P.punctata_SP_Brasil & 0.046 & 0.048 & 0.048 & 0.044 & 0.046 & 0.046 & 0.040 & 0.044 & 0.044 & 0.046 & & & & \\
\hline 12_P.edwardsii_Panamá_PAC & 0.050 & 0.042 & 0.042 & 0.048 & 0.050 & 0.050 & 0.044 & 0.048 & 0.031 & 0.034 & 0.038 & & & \\
\hline 13_P.townsendi_Panamá_PAC & 0.059 & 0.057 & 0.057 & 0.057 & 0.059 & 0.059 & 0.053 & 0.057 & 0.036 & 0.042 & 0.046 & 0.038 & & \\
\hline 14_A.intermedia_FL_EUA & 0.065 & 0.063 & 0.063 & 0.063 & 0.065 & 0.065 & 0.063 & 0.063 & 0.065 & 0.071 & 0.061 & 0.071 & 0.069 & \\
\hline 15_I.subglobosa_México_ATL & 0.069 & 0.065 & 0.065 & 0.067 & 0.069 & 0.069 & 0.067 & 0.067 & 0.063 & 0.069 & 0.067 & 0.071 & 0.076 & 0.052 \\
\hline
\end{tabular}

As análises de distância para as sequencias de COI e $16 \mathrm{~S}$ foram indicativos de confiabilidade, tendo em vista que os valores de divergência genética interespecífica foram maiores do que os da divergência genética intraespecífica. Em resumo, as análises de distância com espécimes de Persephona, mostraram que a variabilidade genética encontrada entre " $P$. crinita", "P. finneganae" e P. lichtensteinii do Atlântico Sul, não é um indicativo de diferenciação em nível específico, permitindo o assinalamento destas em espécies distintas. Entretanto, quando comparadas com P. crinita dos Estados Unidos - Golfo do México, esta variação foi maior que 10\% para COI e 3,2\% para 16S, resultado que evidencia diferenciação em nível específico, suportando a separação dos espécimes do Atlântico Sul e Golfo do México, o que corroborando as análises morfológicas e as sugestões anteriormente propostas por Holthuis (1959) e Torres (1998). Já nas análises de P. lichtensteini do Caribe e Atlântico Sul e "P. mediterranea" do Golfo do México e P. mediterranea do Atlântico Sul, foi verificado que as divergências para ambos os genes, 3\% para COI e $1 \%$ para $16 S$, podem indicar uma diferenciação em nível intraespecífico. No entanto, não se observou evidências suficientes na morfologia para a 
separação dos espécimes de P. lichtensteinii do Caribe e Atlântico Sul. Já os caracteres entre os espécimes de "P. mediterranea" do Golfo do México e $P$. mediterranea do Atlântico Sul, mantiveram-se constantes. Tais observações são indicativas de que os dois grupos sejam distintos e que "P. mediterranea" do Golfo do México seja, na verdade, P. aquilonaris e os espécimes do Atlântico Sul, P. mediterranea.

Segue um mapa com a distribuição dos espécimes analizados na morfologia e molecular, após a revisão taxonômica (Fig. 20).

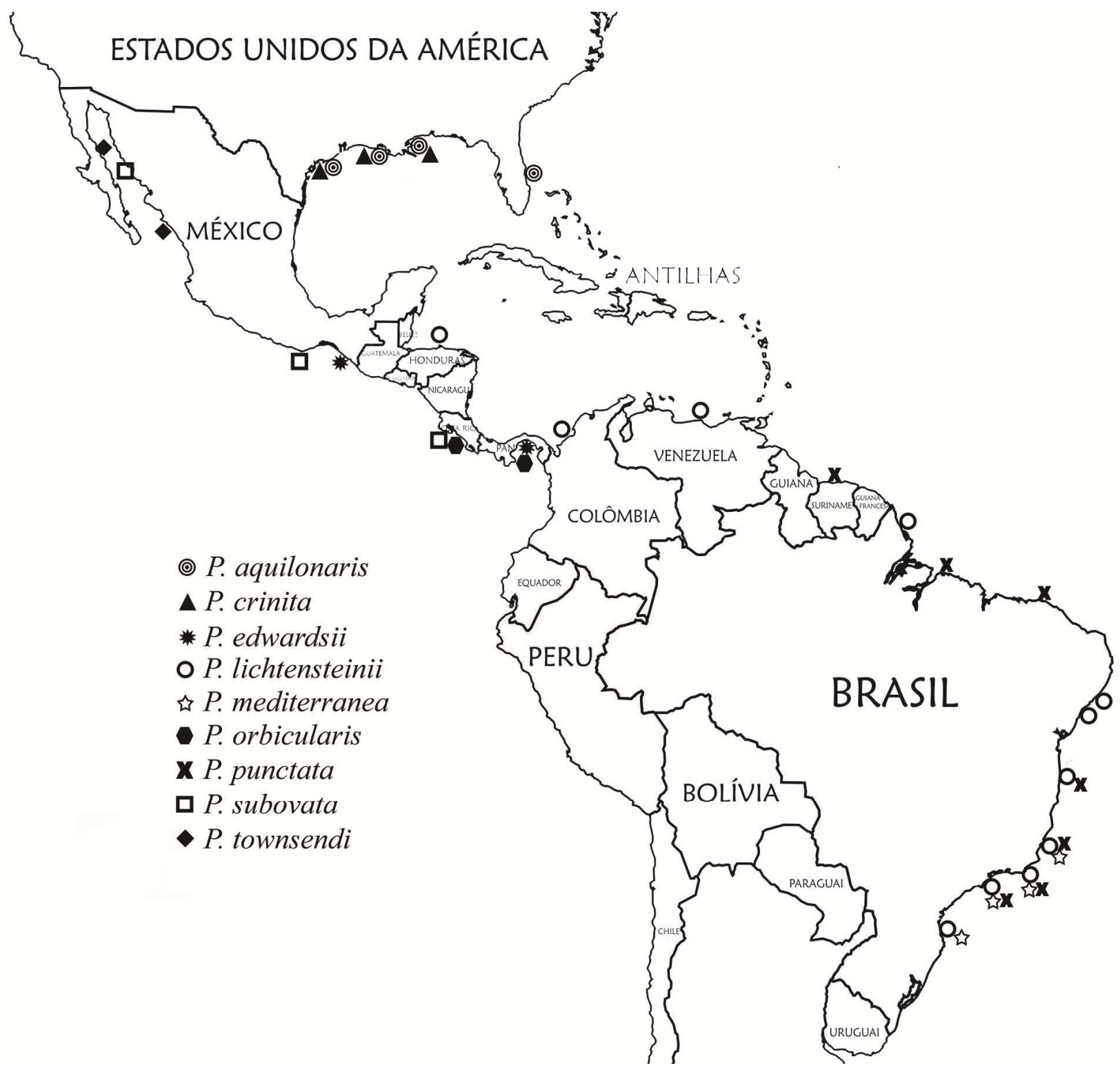

Fig. 20. Mapa com distribuição dos espécimes de Persephona analisados, após revisão taxonômica. 
Análises filogenéticas

Análises numéricas utilizando os critérios de Máxima Verossimilhança (MV) e Máxima Parcimônia (MP), para os genes COI e 16S, foram utilizados na construção de hipóteses filogenéticas do gênero Persephona. Para cada gene existe uma composição distinta dos táxons terminais utilizados nas análises, sendo os táxons $P$. orbicularis, P. subovata, I. hancocki, I. intermedia e E. nux incluídos apenas na análise do gene COI e apenas A. intermedia incluída na análise do gene 16S. Essa divergência de espécies entre os genes foi observada devido a amplificação de um ou outro gene para cada espécie.

As topologias resultantes das quatro análises (Figs. 21, 22, 23 e 24) apresentaram uma estruturação semelhante. Foi observado a formação de dois grandes clados dentro do gênero Persephona, sendo um deles constituído por $P$. orbicularis, P. townsendi, P. edwardsii, P. punctata, "P. mediterranea" e $P$. mediterranea (grupo 1) e o outro constituído por "P. crinita", P. crinita, $P$. finneganae e $P$. lichtensteinii (grupo 2). Diferentemente da posição do táxons terminais na análise de $\mathrm{MV}$, na MP, para o mesmo gene, os táxons que compõe o que aqui chamado de grupo 1, não formaram um agrupamento monofilético, pois $I$. intermedia encontra-se inserida nesse grupo. Além disso, os táxons $P$. subovata, "I. hancocki", P. orbicularis e P. townsendi estão inserido no outro agrupamento grupo 2 .

Observou-se que as espécies de Persephona do Atlântico não formaram um grupo monofilético, sugerindo que um ancestral comum foi isolado em clados no Norte e no Sul, antes do fechamento do Istmo do Panamá, assim como obervado para o gênero Austinixa (Harrison, 2004). A especiação em clados no Norte e Sul pôde ter ocorrido antes do fechamento do Istmo, em decorrência das correntes marítimas, as quais apresentavam diferentes direções de fluxos. Uma saindo do Brasil com um ramo em direção ao Sul, outro em 
direção ao Norte, passando pelo Golfo do México e Atlântico e outra conectando o oceano Atlântico e Pacífico (Briggs, 1974).

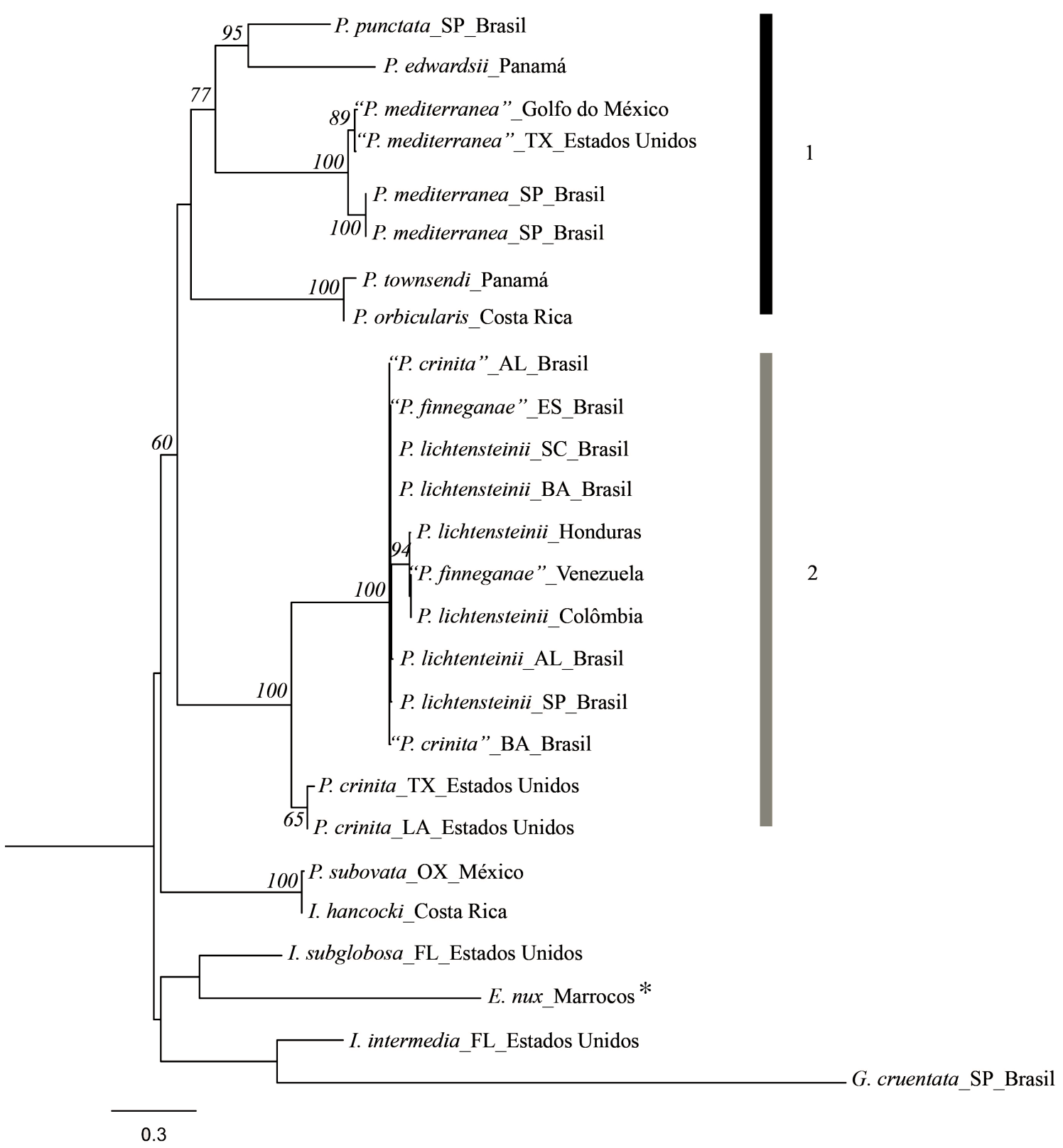

Figura 21. Topologia gerada a partir de análise de Máxima Verossimilhança (MV) para as espécies do gênero Persephona, baseada no gene mitocondrial, citocromo oxidase I (COI), construída no RAxML. Valores dos nós representam o suporte de bootstrap $(\leq 50 \%$ não apresentados); AL: Alagoas; BA: Bahia; ES: Espírito Santo; FL: Flórida; LA: Louisiana; OX: Oaxaca; SC: Santa Catarina; SP: São Paulo; TX: Texas; ATL: A tlântico; PAC: Pacífico. ${ }^{*}$ indica sequência obtida no GenBank. 


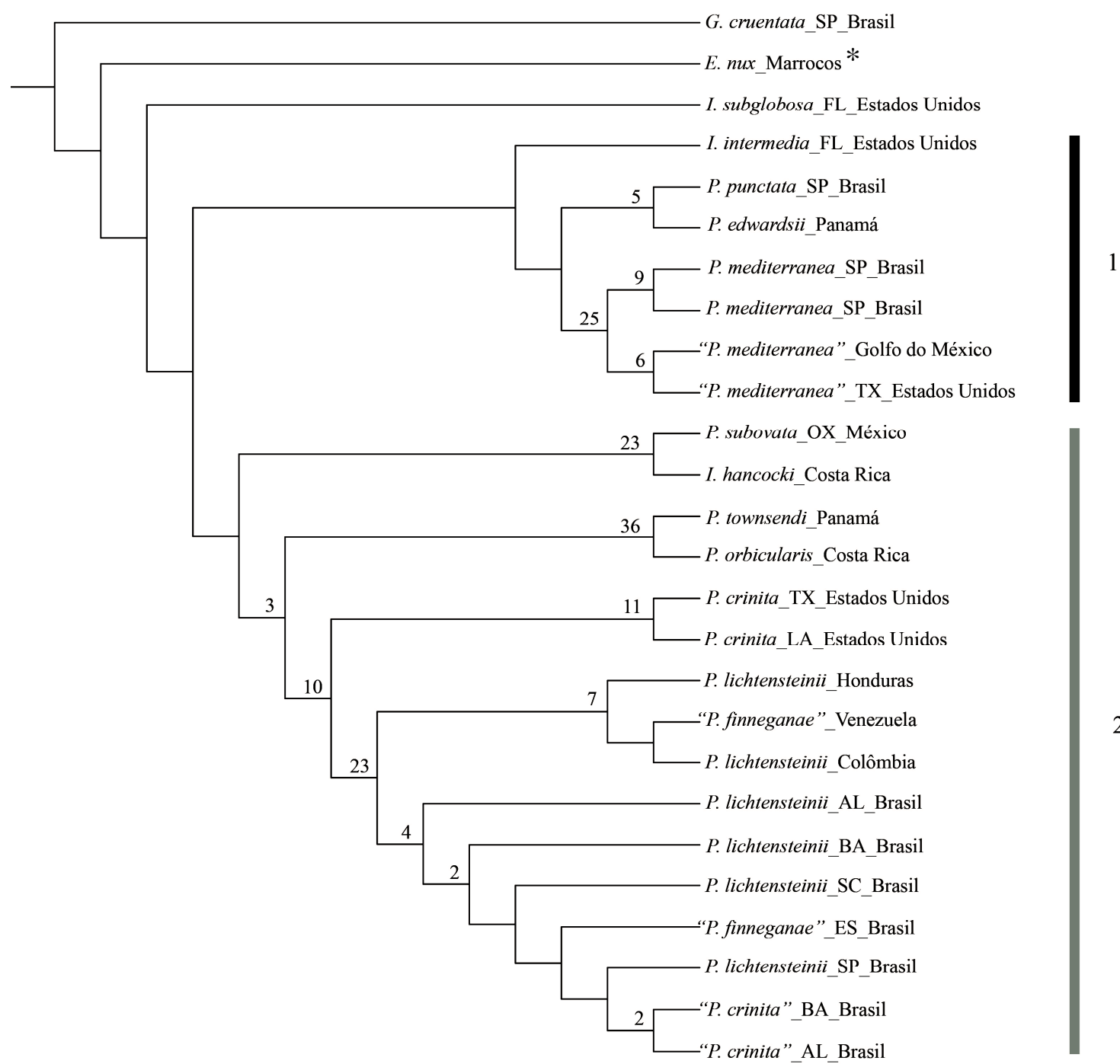

Figura 22. Topologia gerada a partir da análise de Máxima Parcimônia (MP) para as espécies do gênero Persephona, baseada no gene mitocondrial COI, construída no POY. Valores dos nós representam o suporte de Bremer; AL: Alagoas; BA: Bahia; ES: Espírito Santo; FL: Flórida; LA: Louisiana; SC: Santa Catarina; SP: São Paulo; TX: Texas; ATL: Atlântico; PAC: Pacífico. ${ }^{*}$ indica sequência obtida no GenBank. 


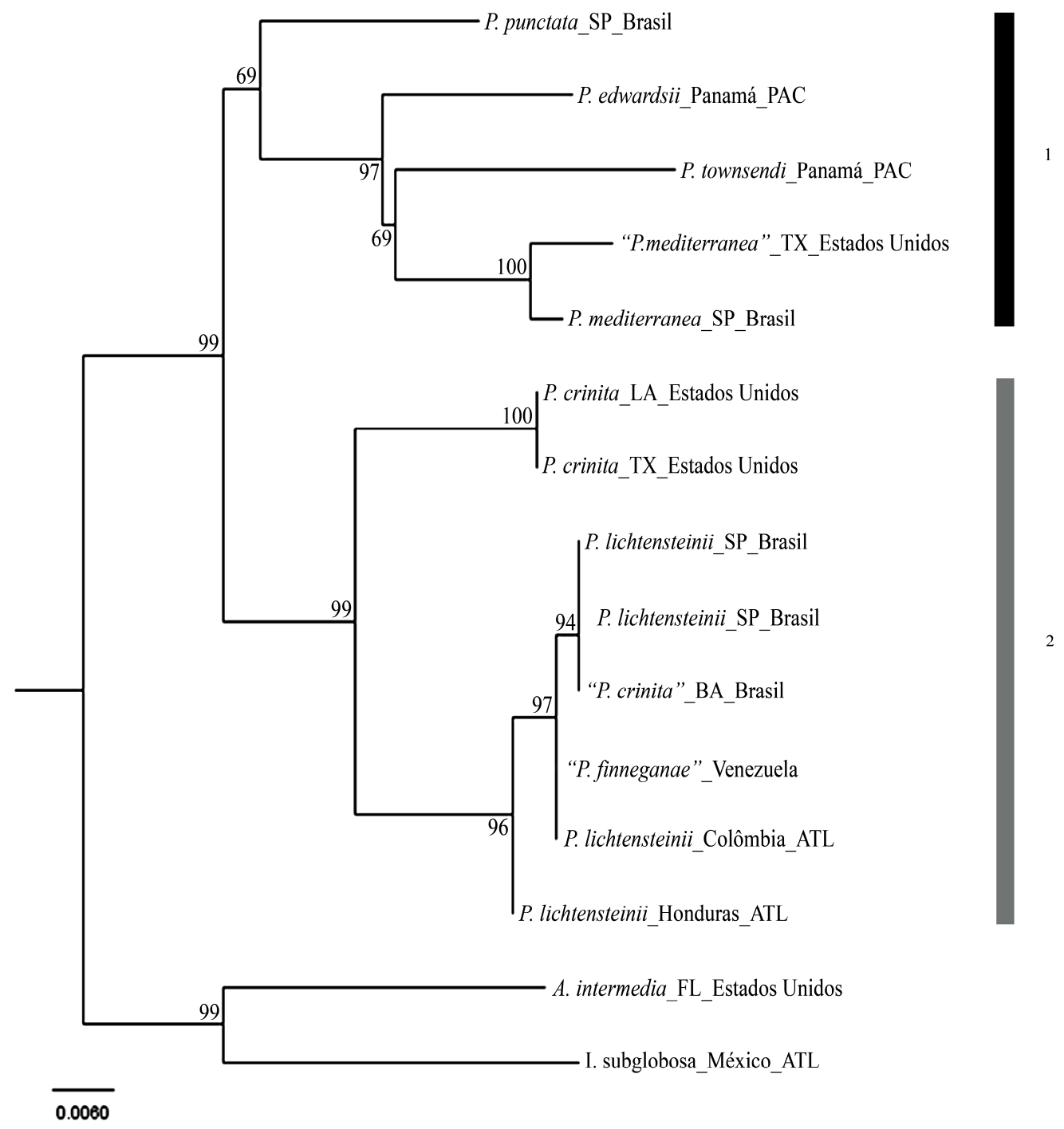

Figura 23. Topologia gerada a partir da análise de Máxima Verossimilhança (MV) para as espécies do gênero Persephona, baseada no gene mitocondrial, 16S, construída no RAxML. Valores dos nós representam o suporte de bootstrap ( $\leq 50 \%$ não apresentados); AL: Alagoas; BA: Bahia; ES: Espírito Santo; FL: Flórida; LA: Louisiana; OX: Oaxaca; SC: Santa Catarina; SP: São Paulo; TX: Texas; ATL: A tlântico; PAC: Pacífico. 


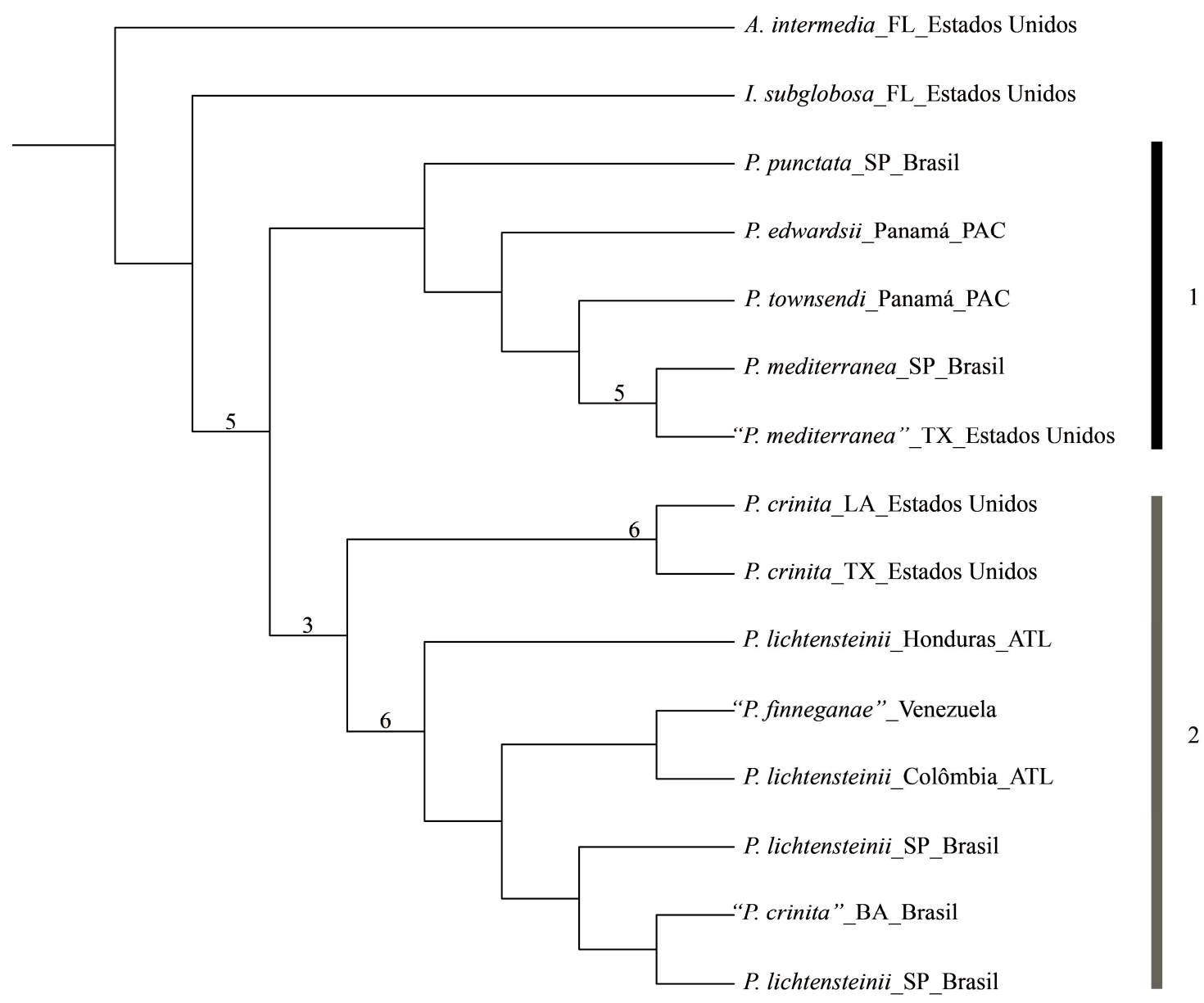

Figura 24. Topologia gerada a partir da análise de Máxima Parcimônia (MP) para as espécies do gênero Persephona, baseada no gene mitocondrial 16S, construída no POY. Valores dos nós representam o suporte de Bremer; BA: Bahia; FL: Flórida; LA: Louisiana; SP: São Paulo; TX: Texas; ATL: Atlântico; PAC: Pacífico.

\section{- "I. hancocki"}

O posicionamento de Iliacantha hancocki dentro de Persephona, em ambas as análises, poderia levantar dúvidas quanto ao monofiletismo do gênero Persephona. No entanto, como proposto nas análises morfológicas de que "I. hancocki" trata-se de um sinônimo júnior de $P$. subovata, descarta-se assim a hipótese de não monofiletismo de Persephona baseando-se apenas nessa espécie, na análise de COI e utilizando a MV. No entanto, na análise de MP, o 
monofiletismo de Persephona ainda pode ser questionado, dado o posicionamento de $I$. intermedia dentro do grupo 1. Porém, a falta de uma análise morfológica de exemplares desta espécie, somado a baixa representatividade de espécies do gênero Iliacantha, não nos permite aqui inferir quanto ao monofiletismo de Persephona em relação à Iliacantha, bem como a possibilidade de I. intermedia ser uma espécie do gênero Persephona. Assim, é sugerido que outras espécies do gênero Iliacantha e de outros gêneros da família Leucosiidae sejam analisados, na tentativa de checar a monofilia do grupo e as relações de $P$. subovata.

- P. subovata (incluindo "I. hancocki")

O posicionamento de $P$. subovata nas análises de COI difere entre as análises utilizando-se de MV e MP (Figs. 21 e 22). Na primeira, P. subovata é o representante mais basal do gênero, enquanto que na análise de MP esta espécie ocupa uma posição mais derivada (Fig. 22). Este táxon forma um agrupamento com "I. hancocki", e assim como discutido na análise morfológica, "I. hancocki" corresponde a um sinônimo júnior de P. subovata.

\section{- P. crinita, P. finneganae e P. lichtensteinii}

Nas análises de MV e MP foi possível observar que todos os táxons já assinalados como $P$. crinita não formam um agrupamento monofilético, sendo que os espécimes de "P. crinita" do Brasil então inseridos em um clado, juntamente com os espécimes de "P. finneganae" e P. lichtensteinii, sendo este grupo irmão do clado contendo as espécies de $P$. crinita dos Estados Unidos Golfo do México (Figs. 21, 22, 23 e 24) (grupo 1). Ademais, na análise de MV utilizando o gene COI (Fig. 21) foi observado que no clado contendo os espécimes de "P. crinita", "P. finneganae" e $P$. lichtensteinii não é observada uma separação dos táxons representando as diferentes espécies já propostas, exceto 
pela formação de um grupo composto pelos táxons de P. lichtensteinii do Caribe. Por sua vez, os resultados das análises utilizando o gene 16S (Figs. 23 e 24) mostram um arranjo diferente para os táxons deste grupo, com as espécies do Caribe formando um grupo parafilético, em relação às espécies do Brasil. Assim, baseado nas duas análises, juntamente com os resultados de análise de distância e morfologia, não é possível estabelecer uma relação consensual quanto ao posicionamento dos grupos do Caribe e Atlântico Sul, sendo necessários outros estudos, larvais e/ou de genética populacional, que permitam esclarecer as relações entre esses grupos. Ademais, a separação do grupo do caribe, juntamente com a divergência genética observada é indício de que os espécimes do Caribe e Atlântico Sul, possam não pertencer a mesma espécie. No entanto, outros estudos com as duas populações devem ser realizados.

Nas análises morfológicas não foram observados caracteres que se mantivessem constantes nos espécimes do Atlântico Sul, havendo um grande intervalo de variação morfológica, principalmente com relação aos espinhos ao redor da carapaça, os quais são muito utilizados para separação das espécies do gênero. Nas chaves de identificação de Rathbun (1937), P. lichtensteinii apresenta espinhos longos e cilíndricos, enquanto $P$. crinita, tubérculos ou grânulos e espinhos posteriores curtos e cônicos. Como discutido na análise morfológica, esses animais apresentam o hábito de se enterrarem (Stevcic, 1973; Taylor, 1984), o que poderia ocasionar o desgaste ou quebras dessas estruturas, gerando erros de identificação entre ambas, ou mesmo possa ser uma variação natural ao longo da ontogenia, como discutido para outros Brachyura. Assim, sem a informação que o tamanho do espinho seja um caráter variável para o gênero e que $P$. crinita descrita para o Golfo do México, apresenta excrescências e não espinhos na margem lateral e subhepática, bem como a estrutura do gonópodo distinta de $P$. lichtensteinii, os espécimes do Atlântico Sul foram, até o 
momento, erroneamente identificados como P. crinita. Desta maneira, podemos propor que $P$. crinita não ocorre no Brasil e que os espécimes outrora assinalados a essa espécie, correspondem na verdade a P. lichtensteinii. Ainda nessse contexto, baseado nessas análises, juntamente com as morfológicas, podemos propor que os espécimes assinalados como $P$. finneganae seja sinônimo júnior de $P$. lichtensteinii.

Considerando a proposta taxonômica em que o grupo 2 é composto por apenas duas espécies P. crinita para o Golfo do México e P. lichtensteinii para o Caribe e Atlântico Sul, eventua-se que tal processo de especiação pode ter ocorrido como consequência ao fechamento do Istmo do Panamá, com a formação de uma barreira geográfica, gerando alterações na dinâmica marinha. Uma das importantes consequências da formação do Istmo compreende o redirecionamento da Corrente Equatorial Norte, em direção ao norte, pela Corrente do Golfo através do Estreito do Yucatán, tornando-se mais intensa do que era antes do fechamento do Istmo (Niegel, 2009). Consequentemente, esse aumento da intensidade teria auxiliado na separação entre os táxons do Golfo do México e Caribe/Atlântico dos EUA (Harrison, 2004). Desta maneira, a especiação alopátrica entre $P$. crinita e $P$. lichtensteinii provamelmente ocorreu pelo isolamento do Golfo do México, como consequência da intensidade do fluxo de corrente marítima, promovendo o endemismo de P. crinita. Apesar de que segundo Niegel (2009), existirem diversos padrões no Golfo do México, que não são completamente compreendidos, mas sugere-se que exista a ação de vários fatores que incluem isolamento passado, barreiras à disperção e seleção natural, e fatores altamente relevantes para a disperção larval planctônica, afetando os níveis de fluxo gênico. 
- P. aquilonaris e $P$. mediterranea

Os resultados das análises de $\mathrm{MV}$ e MP, para o gene COI, mostram que os espécimes de "P. mediterranea" do Golfo do México constituem o grupo irmão dos espécimes de $P$. mediterranea do Brasil (Figs. 21 e 22). Ademais, a existência de ramos com comprimentos diferentes de zero para MV (Fig. 21), juntamente com os altos valores obtidos para os indíces de bootstrap (100) e para o suporte de Bremer (25) em MP (Fig. 22), evidenciam a clara separação dos espécimes já propostos para esta espécie. Desta maneira, esses resultados corroboram as análises de distância e morfologia, em que a variação de 3\% poderia indicar uma variação interespecífica e não intraespecífica, e os caracteres morfológicos, como padrão de coloração da superfície da carapaça e morfologia dos gonópodos, seriam informativos o suficiente para permitir a separação de táxons.

Analisando material proveniente do Golfo do México, observou-se que a preservação dos espécimes em álcool promove, frequentemente, a perda da coloração da carapaça, importante caráter morfológico para a distinção dessas espécies. Isso dificulta a identificação dos espécimes que não são frescos, já que todos os outros caracteres analisados, com excessão do gonópodo, apresentaram-se iguais em todos os espécimes analisados, não permitindo distinta separação entre eles. No entando, o resultado de todas as análises permite fazer inferências de que os espécimes do Golfo do México e do Atlântico Norte, são distintos dos espécimes do Atlântico Sul e Caribe, correspondendo a $P$. aquilonaris e $P$. mediterranea, respectivamente. Rathbun (1933) descreveu P. aquilonaris proveniente de Sta. Augustine na Flórida, na costa leste dos Estados Unidos, sendo que os materiais de "P. mediterranea" coletados no Golfo do México apresentam o mesmo padrão de coloração descrito pela autora (Dr. Darryl L. Felder, comunicação pessoal). 
Na literatura, a distribuição de $P$. aquilonaris é dita de Nova Jersey até Texas (Rathbun, ). No entanto, é relatado para diversos organismos marinhos, que existe variabilidade genética entre os espécimes provenientes do Golfo do México e Atlântico Norte, mesmo que essa divergência genética não seja refletida na morfologia, podendo ou não ocorrer um padrão disjunto das espécies provenientes das duas áreas (Reeb \& Avise, 1990; Felder \& Staton, 1994; Young et al., 2002; Lee \& Foighil, 2005). O padrão disjunto de distribuição das espécies do Golfo do México e Atlântico Norte poderia indicar a ocorrência de vicariância, como consequência do abaixamento do nível do mar, e alterações silmultaneas no clima durante os períodos de glaciações na Terra, resultando no deslocamento dos hábitats estuarinos ao longo da porção Sul da península da Flórida, períodos que possibilitaram interações entre espécimes do Golfo do México e Atlântico Norte. Com o recuo das geleiras, e consequente deslocamento das espécies para o Norte, houve o isolamento de espécimes de ambas as áreas, podendo ter gerado diversas especiações (Reeb \& Avise, 1990, Avise, 1992).

Baseado nesse contexto é possível que o padrão de distribuição atribuido à $P$. aquilonaris esteja equivocado, podendo esta corresponder a mais de uma espécie. No entanto, são realizadas aqui apenas suposições, uma vez que não foi possível realizar análises morfológicas com um maior número de espécies, nem análises moleculares com espécimes do Atlântico Norte. Assim, sugere-se que outros estudos morfológicos e moleculares sejam realizados, no intuito verificar o real padrão de distribuição desta espécie.

A espécie $P$. mediterranea apesar de apresentar um padrão morfológico muito semelhante a $P$. aquilonaris, possui uma distribuição distinta, ocorrendo no Caribe e no Atlântico Sul. A separação entre as duas espécies poderia também ser explicada pelos períodos de glaciação na Terra em que cada avanço e recuo glacial ocorridos no planeta provocaram efeitos sobre o nível do mar, 
níveis de nutrientes e temperaturas da superfície do mar, promovendo, consequentemente, o padrão de distribuição e isolamento dos organismos bentônicos de águas rasas no Atlântico e do Caribe (Harrison, 2004). Outra hipótese de separação de $P$. aquilonaris e $P$. mediterranea seria devido à formação de diferentes províncias no continente americano, a partir de diferenças latitudinais, temperatura e salinidade. Fatores estes que poderiam determinar a o padrão de distribuição de diferentes espécies (Boschi, 2000).

A presença de espécimes de ${ }^{*} P$. mediterranea na costa sudoeste da Flórida pode ser explicada pelos fluxos de correntes marítimas. A corrente de Loop, assim como outras correntes menores, entra no Golfo do México a partir do Mar do Caribe, atravessando o estreito de Yucatán e sai pelo estreito da Flórida (Avise, 1992; Richards et al., 1993; Wicksten \& Packard, 2005). A corrente de Loop é responsável por um sistema dinâmico oceanográfico, no qual reforça a mistura de fauna tropical e temperada, mesopelágica e costeira, bem como espécies demersais e pelágicas (Richards et al., 1993). Dessa maneira, larvas de espécimes do Caribe, poderiam migrar através do fluxo de correntes, podendo se estabelecer na costa sul e sudoeste da Flórida, os quais são rotas de saída dessas correntes. No entanto, sugere-se que outras análises sejam realizadas com espécimes provenientes da Flórida, Caribe e Atlântico Sul, no intuito de checar a validade destes.

\section{- P. orbicularis e P. townsendi}

A espécie $P$. orbicularis foi incluída somente nas análises utilizando-se o gene COI, e os resultados observados foram distintos para as análises de MV e MP. As topologias resultantes das árvores em que $P$. orbicularis está incluida, divergem significativamente das topologias das análises de $16 \mathrm{~S}$. Um das principais diferenças constatadas é quanto ao posicionamento de $P$. townsendi, que nas análises de $16 S$ é encontrado como grupo irmão de $P$. mediterranea e " $P$. 
mediterranea" e nas análises de COI passa a ser grupo irmão de $P$. orbicularis. Além disso, o posicionamento do clado constituído por estes dois taxóns é bastante discrepante entre as duas análises, podendo ocupar tanto uma posição de grupo irmão de $P$. mediterranea, "P. mediterranea", $P$. edwardsii e $P$. punctata (Fig. 21) quanto à posição de grupo irmão de P. crinita e P. lichtensteinii (Fig. 23).

A partir da análise de MV, constatou-se que existe uma pequena divergência entre $P$. orbicularis e $P$. townsendi, o que juntamente com as análises morfológicas pode indicar que $P$. townsendi seja sinonímo júnior de $P$. orbicularis, podendo-se inferir sobre variação populacional. Esse resultado está de acordo com as análises de distância genética e morfológicas, que podem indicar variação intraespecífica entre elas. Rathbun (1937) em sua chave de identificação distingue ambas as espécies pela forma e tamanho dos espinhos da margem subhepática, sendo longos e agudos em $P$. townsendi e curtos e dentiformes em P. orbicularis. No entanto, assim como discutido na morfologia, esses caracteres são bastante variáveis. Além disso, observou-se na MEV que os gonópodos de ambas são bastante semelhantes, podendo indicar que são a mesma espécie. Entretanto, é sugerido que haja um aumento no número de exemplares analisados no intuito de propor uma sinonímia para as duas espécies, bem como para fazer afirmações mais robustas quanto ao posicionamento dessas duas espécies em relação ao gênero Persephona como um todo.

- P. edwardsii e P. punctata

A relação entre as espécies Persephona edwardsii e Persephona punctata são distintas nas análises de COI (Fig. 21 e 22) e 16S (Fig. 23 e 24). Enquanto que nas análises de COI os táxons possuem uma relação de grupo irmão, nas análises de $16 S$ tal relação não é recuperada. Pode-se supor como uma causa dessa mudança à inclusão do táxon $P$. orbicularis nas análises de COI que, como 
exposto no item acima, causa uma mudança significativa nas relações internas do grupo composto por $P$. mediterranea, "P. mediterranea", P. edwardsii e $P$. punctata.

A separação entre $P$. punctata e $P$. edwardsii, possivelmente ocorreu depois do fechamento do Istmo do Panamá, em que a formação dessa barreira física tenha isolado populações do Atlântico e Pacífico, permitindo o acúmulo de diferenciação morfológica e genética, a partir dos quais sejam identificados como táxons distintos. Além disso, observou-se que as diferenças morfológicas, como presença de um dente ou grânulo na margem subhepática em P. punctata, o qual é ausente em P. edwardsii, se manteve constante. Bem como, a proporção das estruturas como própodo do quelípodo e fronte, além da morfologia dos gonópodos, os quais foram bastante diferentes entre ambas as espécies (Fig. 18).

Esse padrão de distribuição entre espécies próximas e separadas entre Atlântico e Pacífico, também foi observada para distintos grupos de crustáceos (Marko, 2002; Robles et al., 2007; Mantelatto et al., 2009a, b). 


\section{Conclusões}


A partir das análises moleculares foi possível observar que os genes mitocondriais COI e 16S, apesar de possuírem carasterísticas distintas quanto à variabilidade e conservação, foram informativos para checar as relações filogenéticas dentro do gênero Persephona. Além disso, as análises de distância genética, Máxima Verossimilhança e método de Máxima Parcimônia, corroboraram as hipóteses de sinonímia e de validade taxonômica das espécies P. aquilonaris, $P$. crinita, $P$. finneganae, $P$. lichtensteinii e $P$. mediterranea. A espécie P. crinita é uma espécie taxonomicamente válida, no entanto com distribuição restrita no Golfo do México, como sugerido por Rathbun (1931); os espécimes do Atlântico Sul identificados como P. crinita correspondem, na realidade, à espécie $P$. lichtensteinii, e $P$. finneganae é sinonímo júnior de $P$. lichtensteinii.

Da mesma forma, $P$. aquilonaris apresenta validade taxonômica e distribuição no Golfo do México e Atlântico Norte, como sugerido por Rathbun, (1933), devendo, entretanto, ser analisado posteriormente esse padrão de distribuição. Já os espécimes de ocorrência no Atlântico Sul e Caribe correspondem à espécie $P$. mediterranea, devendo haver um estudo que abranja uma distribuição maior dessa espécie no intuito de checar a validade dos espécimes observados no Sudeste da Flórida e o padrão biogeográfico da espécie.

A espécie $P$. subovata apresenta validade taxonômica, enquanto $I$. hancocki é um sinônimo júnior dessa, devendo portanto, ser identificado corretamente como P. subovata.

No entanto, outras análises incluindo mais espécimes de Iliacantha, bem como de outros gêneros da família Leucosiidae devem ser realizadas no intuito de testar o monofiletismo do gênero Persephona e as relações internas das espécies que o compõe. 


\section{Referências}


Abele, L.G. \& W. Kim. 1986. An illustrated guide to the marine decapod crustaceans of Florida. Technical Series of the State of Florida Department of Environmental Regulation, $\underline{8}(1): 1-760$.

Abreu, J. 1980. Distribuição e ecologia dos Decapoda numa área estuarina de Ubatuba (SP). Boletim do Instituto Oceanografico, 29(2): 1-3.

Almeida, A.O.; Bezerra, L.E.A.; Souza-Filho, J.F.; Almeida, S.M.; Albuquerque, D.L. \& P.A. Coelho. 2008. Decapod and stomatopod crustaceans from Santo Aleixo Island, State of Pernambuco, Brasil. Nauplius, 16(1): 23-41.

Álvarez, F.; Villalobos, J.L.; Rojas, Y. \& R. Robles. 1999. Listas y comentarios sobre los crustáceos decápodos de Veracruz, México. Anales del Instituto de Biología Universidad Nacional Autónoma de México, Serie Zoología, 70(1): 1-27.

Avise, J.C. 1992. Molecular population structure and the biogeographic history of a regional fauna: a case history with lessons for conservation biology. Oikos, $\underline{63}$ : $62-76$.

Behre, E.H. 1950. Annotated list of the fauna of the Grand Isle region. Occasional Papers Marine Laboratory Louisiana State University, $\underline{6}$ : 1-66.

Bell, T. 1855. Horae carcinologicae, or notices of crustacea. I. A monograph of the Leucosiidae, with observations on the relations, structure, habits and distribution of the family; a revision of the generic characters; and descriptions of new genera and species. Transactions of the Linnean Society of London, 21: 277-314.

Bertini, G.; Fransozo, A. \& G.A.S. Melo. 2004. Biodiversity of brachyuran crabs (Crustacea: Decapoda) from non-consolidated sublittoral bottom on the northern coast of São Paulo State, Brazil. Biodiversity and Conservation, 13: 2185-2207.

Bertini, G.; Teixeira, G.M.; Fransozo, V. \& A. Fransozo. 2010. Reproductive period and size at the onset of sexual maturity of mottled purse crab, Persephona mediterranea (Herbst, 1794) (Brachyura, Leucosioidea) on the southeastern Brazilian coast. Invertebrate Reproduction and Development, $\underline{54}(1):$ 7-17.

Boone, L. 1930. Scientific results of the cruises of the Yachts "Eagle" and "Ara", 19211928, William K. Vanderbilt, commanding. Crustacea: Anomura, Macrura, Schizopoda, Isopoda, Amphipoda, Mysidacea, Cirripedia, and 
Copepoda. Bulletin of the Vanderbilt Marine Museum (Huntington Museum), 3: $11-60$.

Bordin, G. 1987. Brachyura da plataforma continetal do Estado do Rio Grande do Sul, Brasil, e áreas adjacentes (Crustacea: Decapoda). Iheringia Séries Zoologia, 66: 332.

Boschi, E.E. 2000. Species of decapod crustaceans and their distribution in the american marine zoogeographic provinces. Revista de Invetigación y Desarrollo Pesquero, 13: 7-136.

Braga, A.A.; Fransozo, A.; Bertini, G. \& P.B. Fumis. 2005. Composição e abundância dos caranguejos (Decapoda, Brachyura) nas regiões de Ubatuba e Caraguatatuba, litoral norte paulista, Brasil. Biota Neotropica, $\underline{5}(2): 45-78$.

Branco, J.O. \& H. Fracasso. 2004. Biologia populacional de Callinectes ornatus (Ordway) na Armação do Itapocoroy, Penha, Santa Catarina, Brasil. Revista Brasileira de Zoologia, 21(1): 91-96.

Bremer, K. 1988. The limits of amino acid sequence data in angiosperm phylogenetic reconstruction. Evolution. 42(4): 795-803.

Bremer, K. 1994. Branch support and tree stability. Cladistics. 10(3): 295-304.

Briggs, J.C. 1974. Marine Zoogeography. McGraw-Hill, New York.

Browne, P. 1756. The civil and natural history of Jamaica. In Three Parts. Containing, I. Anaccurate Description of that Island, its Situation and Soil; with a brief Account of its former and present State, Government, Revenues, Produce, and Trade. II. A History of the natural Productions, including the various Sorts of native Fossils; perfect and imperfect Vegetables; Quadrupedes, Birds, Fishes, Reptiles and Insects; with their Properties and Uses in Mechanics, Diet, and Physic. III. An Account of the Nature of Climates in general, and their different Effects upon the human Body; with a Detail of the Diseases arising from this Source, particularly within the Tropics. In Three Dissertations, 503pp.

Buitendijk, A.M. 1950. Notes on a collection of decapoda brachyuran from the coasts of Mexico, including the description of a new genus and species. Zoologische Mededelingen, 30: 269-282. 
Burkenroad, M.D. 1963. The evolution of the Eucarida, (Crustacea, Eumalacostraca), in relation to the fossil record. Tulane Studies in Geology, 2(1): 3-17.

Camp, D.K.; Lyons, W.G. \& T.H. Perkins. 1998. Checklist of shallow-water marine malacostracan Crustacea of Florida. In: Camp, D.K.; Lyons, W.G. \& T.H. Perkins (eds.) Checklists of selected shallow-water marine invertebrates of Florida. St. Petersburg, FL: Florida Department of Environmental Protection, 123-189.

Carvalho, F.L.; Carvalho, E.A.S. \& E.C. Guerreiro. 2010. Comparative analysis of the distribution and morphological sexual maturity of Persephona lichtensteinii e $P$. punctata (Brachyura, Leucosiidae) in Ilhéus, BA, Brasil. Nauplius 18(2): 109-115.

Chen, H. \& H. Sun, 2002. Arthropoda Crustacea Brachyura marine primitive crabs. Fauna Sinica, Invertebrata: 30, Science Press, Beijing, 597pp.

Coelho, P.A. 1969. A distribuição dos crustáceos decápodos reptantes do Norte do Brasil. Trabalhos Oceanográficos da Universidade Federal de Pernambuco, 9/11(1967/69): 223-238.

Coelho, P.A. \& M.A. Ramos. 1972. A constituição e distribuição da fauna de decápodos do litoral leste da América do Sul, entre as latitudes de $5^{\circ} \mathrm{N}$ e $39^{\circ} \mathrm{S}$. Trabalhos Oceanográficos da Universidade Federal de Pernambuco, 13: 245-260.

Coelho, P.A. \& M.F.A. Torres. 1980. Zoogeografia marinha do Brasil. II. Considerações ecológicas e biogeográficas sobre a família Leucosiidae (Decapoda, Brachyura). Revista Nordestina de Biologia, 3: 67-77.

Coelho, P.A.; Ramos-Porto, M. \& T.C.S. Calado. 1983. Litoral de Alagoas e Sergipe. Anais da Sociedade Nordestina de Zoologia, 1(1): 133-155.

Coelho, P.A.; Ramos-Porto, M.A. \& T.C.S. Calado. 1986. Litoral do Rio Grande do Norte: Decapoda. Cadernos Ômega da Universidade Federal Rural de Pernambuco, Série Ciências Aquáticas, 2: 79-105.

Coelho, P.A.; Almeida, A.O. \& L.E.A. Bezerra. Checklist of the marine and estuarine Brachyura (Crustacea: Decapoda) of northern and northeastern Brazil. Zootaxa, 1956: 1-58.

Collins, J.S.H.; Donovan, S.K. \& T.A. Stemann. 2009. Fossil Crustacea of the Port Morant Formation. Scripta Geologica, 138: 23-53. 
Compton, H. 1962. Survey of the comercial shrimp and associated organisms of Gulf Area 20, 19pp.

Correa-Sandoval, F. 1991. Catálogo y bibliografía de los cangrejos (Brachyura) del Golfo de California. Comunicaciones Académicas, CICESE. Serie de Acuicultura. B.C., México, 117pp.

Del Solar, E.M. 1970. Crustáceos braquiuros (Cangrejos), anomuros y estomatópodos de las zonas nerito-pelágica y litoral de Tumbes. Boletin de la Sociedad Geográfica de Lima, 89: 40-48.

Desbonne, I. 1867. Pinnotheres barbata. In: Desbonne, I. \& A. Schramm (eds) Crustadés de la Guadeloupe d'apres un manuscrit du Docteur Isis Desbonne comparé avec les echantillons de Crustacés de sa collection et les demières publications de M. M. Henri de Saussure et William Stimpson. Ière partie, Brachyures, 60pp.

Donovan, S.K.; Portell, R.W. \& J.S.H. Collins. 2003. Cretaceous and Cainozoic decapod crustaceans of Jamaica. Contributions to Zoology, 72: 105-109.

Fabricius, J.C. 1798. Supplementum Entomologiae Systematicae. Hafniae: Proft et Storch, $572 \mathrm{pp}$.

Fausto-Filho, J. 1966. Primeira contribuição ao inventário dos crustáceos decápodos marinhos do nordeste brasileiro. Arquivos Estaduais de Biologia Marinha da Universidade Federal do Ceará, $\underline{6}(1): 31-37$.

Fausto-Filho, J. 1968. Crustáceos decápodos de valor comercial ou utilizados como alimento no nordeste brasileiro. Boletim da Sociedade Cearense de Agronomia. Fortaleza, 9: 462-468.

Felder, D.L. 1973. An annotated key to crabs and lobsters (Decapoda, Reptantia) from coastal waters of the northwestern Gulf of Mexico. Center for Wetland Resources, Louisiana State University LSU-SG-73-02: 1-103.

Felder, D.L. \& J.L. Staton. 1994. Genetic differentiation in trans-Floridian species complexes of Sesarma and Uca (Decapoda: Brachyura). Journal of Crustacean Biology, 14(2): 191-209.

Felder, D.L. \& D.K. Camp. 2009. Gulf of Mexico Origin, Waters, and Biota. Vol. 1, Biodiversity, College Station, Texas: Texas A\&M University Press, 1384pp. 
Felsenstein, J. 1985. Confidence limits on phylogenies: an approach using the bootstrap. Evolution, 39: 783-791.

Finnegan, S. 1931. Report on the Brachyura collected in Central America, the Gorgona and Galapagos Islands, by Dr. Crossland on the 'St. George' expedition to the Pacific, 1924-25. Journal of the Linnean Society of London. Zoology, 37(255): 607-673.

Folmer, O.; Black, M.; Hoeh, W.; Lutz, R. \& R. Vrijenhoek. 1994. DNA primers for the amplification of mitochondrial cytochrome c oxidase subunit I from diverse metozoan invertebrates. Molecular Marine Biology Biotechnology, 3: 294-299.

Galil, B.S. 2001. A revision of Myra Leach, 1817 (Crustacea: Decapoda: Leucosioidea). Zoologische Mededelingen, $\underline{75}$ (24): 409-446.

Garth, J.S. 1946. Littoral brachyuran fauna of the Galapagos Archipelago. Allan Hancock Pacific Expedition, $\underline{5}(10):$ 341-601.

Garth, J.S. 1948. The Brachyura of the "Askoy" Expedition, with remarks on carcinological collecting in the Panama Bight. Bulletin of the American Museum of Natural History, 92(1): 1-66.

Garth, J.S. 1960. Distribution and Affinities of the Brachyuran Crustacea. Systematic Zoology, 9 (3/4): 105-123.

Garth, J.S. 1966. Eastern Pacific Expeditions of the New York Zoological Society. XLVI. Oxystomatous and allied crabs from west cost of tropical America. Zoologica, $\underline{51}$ : $1-16$.

Gibbes, L.R. 1850. On the carcinological collections of the cabinets of natural history in the United States: with an enumeration of the species contained therein, and descriptions of new species. Proceedings of the American Association for the Advancement of Science, 3: 165-201.

Glaessner, M.F. 1969. Decapoda. Treatiseon Invertebrate Palaeontology In: Moore, R.C. (ed.). Arthropoda 4. Part R. Vol. 2. Lawrence, Kansas: The University of Kansas Press and The Geological Society of America, 399-533, 626-628.

Gomes-Corrêa, M.M. \& I.N. Silva-Brum. 1980. Lista dos crustáceos decápodes e estomatópodes do extremo norte do Brasil, coletados pelo navio oceanográfico 
"Almirante Saldanha". Atas da Sociedade de Biologia do Rio de Janeiro, 21: 5964.

Guinot-Dumortier, D. 1959. Sur une collection de Crustacés (Decapoda Reptantia) de Guyane française. I. Brachyura (Oxyrhyncha exclus). Bulletin du Muséum National d'Histoire Naturelle, 31(5): 423-434.

Hall, B.G. 2011. Phylogenetic trees made easy: A how-to manual. 4rd edition. Sinauer Associates, Inc. Sunderland, Massachussets, USA, 233pp.

Hall, T. 2005. BioEdit v.7.0.5. Biological sequence alignment editor for windows. Ibis Therapeutics a division of Isis pharmaceuticals http://www.mbio.nesu.edu/bioefit.html.

Harrison J.S. 2004. Evolution, biogeography, and the utility of mitochondrial $16 S$ and COI genes in phylogenetic analysis of the crab genus Austinixa. Molecular Phylogenetic and Evolution, 30: 743-754.

Harrison, R.G. 1989. Animal mitochondrial DNA as a genetic marker in population and evolutionary biology. Trends in Ecology \& Evolution, $\underline{4}(1)$ : 6-11.

Hay, W.P. \& C.A. Shore. 1918. Decapod crustaceans of the Beaufort, North Carolina region. Bulletin of the Bureau of Fisheries, 35: 369-475.

Hendrickx, M.E. 1993. Crustáceos decápodos bentónicos del sur de Sinaloa, México. Anales del Instituto de Biología, Universidad Nacional Autónoma de México, Serie Zoología, 64(1): 1-16.

Hendrickx, M.E. 1995. Checklist of brachyuran crabs (Crustacea: Decapoda) from the eastern tropical Pacific. Bulletin de l'Institut Royal des Sciences Naturelles de Belgique, Biologie, 65: 125-150.

Hendrickx, M.E. 1997. Los Cangrejos Braquiuros (Crustacea: Brachyura: Dromiidae, Hasta Leucosiidae) Del Pacífico Mexicano. Estación Mazatlán del Instituto de Ciencias del Mar y Limnología, Sinaloa, México, 178p.

Herbst, J.F.W. 1782-1804. Versuch einer Naturgeschichte der Krabben und Krebse, nebst einer systematischen Beschereibung ihrer verschiedenen Arten. Berlin and Stralsund, $\underline{3}(4): 1-274$. 
Hildebrand, H.H. 1954. A study of the fauna of the brown shrimp (Penaeus aztecus Ives) grounds in the western Gulf of Mexico. Publications of the Institute of Marine Science, University of Texas, $\underline{3}: 229-366$.

Hillis, D.M. 1991. Discriminating between phylogenetic signal and random noise in DNA sequences. In: Miyamoto, M.M. \& J. Cracraft (eds). Phylogenetic Analysis of DNA Sequences. Oxford University Press, Oxford. Pp. 278-294.

Hillis, D.M. \& J.P. Huelsenbck. 1992. Signal, noise, and reability in molecular phylogenetic analyses. Journal of Heredity, 3: 180-195.

Hirose, G.L.; Gregati, R.A.; Fransozo, A. \& M.L. Negreiros-Fransozo. 2012. Morphological and morphometric comparations of the first zoea of four species of purse crabs (Decapoda: Brachyura: Leucosiidae) from Brazilian South Atlantic. Zootaxa, 3167: 17-31.

Holthuis, L.B. 1959. The Crustacea Decapoda of Suriname (Dutch Guiana). Zoologischer Verhandelingen, 44 (1): 1-296.

Humes, A.G., 1941. Notes on Octolasmis mulleri (Coker), a barnacle commensal on crabs. Transactions of the American Microscopical Society, 60(1): 101-103.

Hyodo, C.M. 1996. Biologia Populacional do Gênero Persephona Leach, 1817 (Crustacea, Decapoda, Leucosiidae) na Região de Ubatuba, SP. Instituto de Biociências, Universidade Estadual Paulista, Botucatu (SP), 131pp. Tese de Doutorado.

Keunecke, K.A.; Vianna, M.; Fonseca, D.B. \& F. D'Incao. 2007. The ponk-shrimp trawling bycatch in the northern coast of São Paulo, Brazil, with enphasis on crustaceans. Nauplius, $\underline{15}(2):$ 49-55.

Kingsley, J.S. 1878-1879. List of Decapod Crustacea of the Atlantic Coast, whose range embraces Fort Macon. Proceedings of the Academy of Natural Sciences of Philadelphia, 30: 316-328, 329-330.

Latreille, P.A. 1803. Histoire naturelle, génerale et particulière, des Crustacés et des Insectes. Ouvrage faissant suite aux oevres de Leclerc de Buffon, et partie du cours complet d'histoire naturelle rédigé par C.S. Sonnini, membre de plusieurs sociétés savantes. Vol. 5. Paris: Dufart. 
Leach, W.E. 1817. Monograph on the Genera and Species of the Malacostracous Family Leucosidea. In: Leach, W.E. (ed.) The Zoological Miscellany; being descriptions of new, or interesting animals. Vol. 3. Covent Garden e London: E. Nodder e Son. 17-26pp.

Lee, T. \& D. Foighil. 2005. Placing the floridian marine genetic disjunction into a regional evolutionary context using the scorched mussel, Brachidontes Exutus, species complex. Evolution, 59: 2139-2158.

Lemaitre, R. \& R. Alvarez-León. 1991. Crustáceos decápodos del Pacífico colombiano: lista de especies y consideraciones zoogeográficas. Anales del Instituto de Investigaciones Marinas de Punta Betín, 21: 33-76.

Lemos de Castro, A. 1962. Sobre os crustáceos referidos por Marcgrave em sua “História Naturales Brasiliae” (1648). Arquivos do Museu Nacional, 52: 37-51.

Lichtenstein, K.H. 1815. Die Gattung Leucosia. Als Probe einer neuen Bearbeitung der Krabben und Krebse. Magazin der Gesellschaft Naturforschender Freunde zu Berlin, fur die neusten Entdeckungen in der gesammten Naturkunde, 7: 135-144.

Linnaeus, C. 1758. Systema Naturae per Regna Tria Naturae, Secundum Classes, Ordines, Genera, Species, cum Characteribus, Differentiis, Synonymis, Locis. (10 Edition) Vol. 1. Holmiae: Laurentii Salvii. iii, 824 pp.

Lucas, P.H. 1840. Histoire Naturelle des crustacés, des arachnids et des myriapodes. Paris. 600pp.

Luederwaldt, H. 1919. Lista dos crustáceos superiores (Thoracostraca) do Museu Paulista que foram encontrados no estado de São Paulo. Revista do Museu Paulista, 11: 427-435.

Manning, R.B. \& L.B. Holthuis. 1981. West African brachyuran crabs (Crustacea, Decapoda). Smithsonian Contributions to Zoology, 306: 1-379.

Mantelatto, F.L.M. \& A. Fransozo. 2000. Brachyuran community in Ubatuba Bay, Northern Coast of São Paulo State, Brasil. Journal of Shellfish Research. 19(2): 701-709.

Mantelatto, F.L.; O'Brien, J.J. \& R. Biagi. 2003. Parasites and symbionts of crabs from Ubatuba Bay, São Paulo State, Brasil. Comparative Parasitology, 70(2): 211-214. 
Mantelatto, F.L.; Pardo, L.M.; Pileggi, L.G. \& D.L. Felder. 2009a. Taxonomic reexamination of the hermit crab species Pagurus forceps and Pagurus comptus (Decapoda: Paguridae) by molecular analysis. Zootaxa, 2133: 20-32.

Mantelatto, F.L.; Robles, R.; Schubart, C.D. \& D.L. Felder. 2009b. Molecular Phylogeny of the genus Cronius Stimpson, 1860, with reassignment of C. Tumidulus and several american species of Portunus to the genus Achelous De Haan, 1833 (Brachyura: Portunidae). In: Martin, J.W.; Crandall, K.A. \& D.L. Felder (eds), Crustacean Issues 18: Decapod Crustacean Phylogenetcis. Boca Raton, Flórida. Taylor \& Francis/CRC press. 567-579pp.

Mantelatto, F.L.; Fernandes-Góes, L.C.; Fantucci, M.Z.; Biagi, R.; Pardo, L.M. \& J.M. Góes. 2010. A comparative study of population traits between two South American populations of the striped-legged hermit crab Clibanarius vittatus. Acta Oecologica, $\underline{36}(1): 10-15$.

Marko, P.B. 2002. Fossil calibration of molecular clocks and the divergence times of geminate species pairs separated by the Isthmus of Panama. Molecular biology and evolution, 19(11): 2005-2021.

Martens, E., von. 1872. Über cubanische Crustaceen nach den Sammlungen Dr. J. Gundlach's. Archiv für Naturgeschichte, $\underline{38(1): 77-147 .}$

Martin, J.W.; Crandall, K.A. \& D.L. Felder. 2009. Preface. In: Martin, J.W; Crandall, K.A, \& D.L. Felder (eds.) Decapod Crustacean Phylogenetics. Crustacean Issues. Koenemann, S. (series ed.) Vol. 18. Boca Raton, London, New York: CRC Press, Taylor \& Francis Group, 9-11pp.

Martínez, G., Scarabino, F. \& E. Delgado. 2009. New records of the brachyuran crabs Hepatus pudibundus (Aethridae) and Persephona mediterranea (Leucosiidae) in their southernmost Western Atlantic distribution. Pan-American Journal of Aquatic Sciences, $\underline{4}(3):$ 279-282.

Martínez-Iglesias, J.C. \& H.D. Gómez. 1986. Los crustáceos decápodos del Golfo de Batabanó. Brachyura. Poeyana, 332: 5-91.

Melo G.A.S. \&Torres M.F.A. 1998. O gênero Speloeophorus (Decapoda, Brachyura, Leucosiidae) no litoral Brasileiro, com descrição de uma nova espécie. Iheringia, Série Zoologia, 84: 129-132. 
Melo, G.A.S., 1989. A ocorrência de Bellia picta H. Milnie Edwards no litoral brasileiro e considerações sobre a situação atual da Família Belliidae Dana (Crustacea: Decapoda: Brachyura). Atlântica, 11(1): 5-12.

Melo, G.A.S., 1996. Manual de Identificação dos Brachyura (Caranguejos e Siris) do litoral brasileiro. Editora Plêiade, São Paulo, Brasil, 603pp.

Miers, E.J. 1886. Report on the Brachyura collected by H.M.S. Challenger during the years 1873-1876. In: Murray, J. (ed.) Zoology. Report on the Scientific Results of the Voyage of H.M.S. Challenger During the Years 1873-76 Under the Command of Captain George S. Nares, R.N., F.R.S. and the Late Captain Frank Tourle Thomson, R.N. Wyville Thomson, C. and J. Murray (series eds.). Vol. 17. Edinburgh: Neill and Company, 362pp.

Milne Edwards, H. 1837. Histoire naturelle des crustacés comprenant I'anatomie, la physiologie et la classification de ces animaux. Paris, vol. 2: 532pp.

Milne-Edwards, A. 1865. Descriptions de quelques Crustacés nouveaux appartenant a

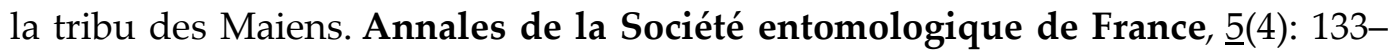
147.

Milne-Edwards, A. 1883. Receuil de figures de crustacés nouveaux ou peu connus, 3 pp.

Moreira, C. 1901. Contribuições para o conhecimento da fauna brazileira. Crustaceos do Brazil. Archivos do Museu Nacional do Rio de Janeiro, 11: 1-151.

Moreira, C. 1903. Crustáceos da Ponta da Pharol, em São Francisco do Sul no Estado de Santa Catarina. Arquivo do Museu Nacional, 12: 119-123.

Moreira, M.C. 2011. Diversidade, ocorrência e distribuição da fauna de invertebrados demersal das baías norte e sul de Florianópolis (SC), Brasil. Universidade Federal de Santa Catarina, Florianópolis, 77pp. Dissertação de mestrado.

Moritz, C., Dowling, T.E., \& W.M Brown. 1987. Evolution of animal mitochondrial DNA: relevance for population biology and systematics. Annual Review of Ecology and Systematics, 18: 269-92.

Murphy, N.P. \& C.M. Austin. 2003. Molecular taxonomy and phylogenetics of some species of Australian palaemonid shrimps. Journal of Crustacean Biology, 23(1): 169-177. 
Negreiros-Fransozo, M.L.; Fransozo, A. \& N.J. Hebling. 1989. Larval development of Persephona mediterranea (Herbst, 1794) (Brachyura, Leucosiidae) under laboratory conditions. Crustaceana, $\underline{57}(2): 177-193$.

Nei, M. 1991. Relative efficiencies of different tree making methods for molecular data. In: Miyamoto.M.M. \& J.L. Cracraft (eds). Recent Advances in Phylogenetic Studies of DNA Sequences. Oxford University Press, Oxford. 90-128.

Neigel, J.E. 2009. Populations genetics and Biogeographic of the Gulf of Mexico. In. Gulf of Mexico. Origin, waters and biota. Felder, D.L. \& D.K. Camp. (eds). Texas A\&M Press. 1393pp.

Ng, P.; Guinot, D. \& P. Davie. 2008. Systema Brachyororum: Part I. An annotated checklist of extant brachyuran crabs of the world. The Raffles Bulletin of Zoology, Supplement, 17: 1-286.

Nobre, A. 1936. Fauna marinha de Portugal. IV. Crustáceos decápodos e stomatópodos marinhos de Portugal. Porto, 213 pp.

Ortíz, M. \& M.A. Olcha. 2011. Restauración y actualización taxonómica de la colección de crustáceos (Arthropoda: Crustacea) de Juan C. Gundlach. Novitates Caribaea, 4: $45-53$.

Overstreet, R.M. \& R.W. Heard. 1978. Food of the Atlantic croaker, Micropogonias undulatus, from Mississippi Sound and the Gulf of Mexico. Gulf Research Reports, $\underline{6}:$ 145-152.

Parra, A. 1787. Descripción de diferentes piezas de historia natural, la más del ramo marítimo, representadas en setenta y cinco láminas. En la Imprenta de la Capitanía General, Habana Cuba: 201pp.

Paul, R.K.G \& M.E. Hendrickx. 1980. Crustaceans in the shrimp by-catch from off the coasts of Sinaloa and Nayarit, México. Bulletin Southern California Academy of Sciences, $\underline{79}(3):$ 109-111.

Pennant, T. 1777. Crustacea. Testacea. Mollusca. British Zoology, 4th ed. Pennant, T. (ed.) Vol. 4. London: B. White, $136 \mathrm{pp}$.

Pileggi, L.G. \& F.L. Mantelatto. 2010. Molecular phylogeny of the freshwater prawn genus Macrobrachium (Decapoda, Palaemonidae), with emphasis on the 
relationships among selected American species. Invertebrate Systematics, $\underline{24}(2)$ : 194-208.

Powers, L.W. 1977. A catalogue and bibliography to the crabs (Brachyura) of the Gulf of Mexico. Contributions in Marine Science, 20: 1-190.

Rambaut, A. 2009. FigTree v1.3.1. (http://tree.bio.ed.ac.uk). Institute of Evolutionary Biology, University of Edinburgh.

Rathbun, M.J. 1893. Scientific results of explorations by the U.S. Fish Commission steamer Albatross. No. XXIV. Descriptions of new genera and species of crabs from the west coast of North America and the Sandwich Islands. Proceedings of the United States National Museum, 16(933): 223-260.

Rathbun, M.J. 1898. The Brachyura collected by the U.S. Fish Commission steamer Albatross on the voyage from Norfolk, Virginia, to San Francisco, California, 1887-1888. Proceedings of the United States National Museum, 21: 567-616.

Rathbun, M.J. 1901. The Brachyura and Macrura of Porto Rico. Bulletin of the United States Fish Commission, 20(2): 1-127.

Rathbun, M.J. 1902. Descriptions of new decapod crustaceans from the west coast of North America. Proceedings of the United States National Museum, 24(1272): 885-905.

Rathbun, M.J. 1910. The stalk-eyed Crustacea of Peru and the adjacent coast. Proceedings of the United States National Museum, 38: 531-620.

Rathbun, M.J. 1931. New crabs from the Gulf of Mexico. Journal of the Washington Academy of Science, 21: 125-128.

Rathbun, M.J. 1933. Descriptions of new species of crabs from the Gulf of California. Proceedings of the Biological Society of Washington, 46: 147-150.

Rathbun, M.J. 1935. Preliminary desciptions of seven new species of oxystomatous and allied crabs. Proceedings of the Biological Society of Washington, $\underline{48}$ : 1-4.

Rathbun, M.J. 1937. The Oxystomatous and allied crabs of America. Bulletin of the United States National Museum, 166: 1-278.

Raz-Guzman, A. \& A.J. Sánchez, 1992. Registros adicionales de cangrejos braquiuros (Crustacea: Brachyura) de Laguna de Términos, Campeche. Anales del Instituto 
de Biologia, Universidad Nacional Autónoma de México Serie Zoologia, $\underline{63}(1)$ : 29-45.

Reeb, C.A. \& J.C. Avise. 1990. A genetic discontinuity and a continuously distributed species: Mitochondrial DNA in the American Oyster, Crassostea virginica. Genetics, 124: 397-406.

Richards, W.J.; McGowan, M.F.; Leming, T.; Lamkin, J.T. \& S. Kelley. 1993. Larval fish assemblages at the loop current boundary in the Gulf of Mexico. Bulletin of Science, $\underline{53}(2):$ 475-537.

Rieger, P.J.; Giraldi, J. \& C.C. Veiga. 1999. Persephona lichtensteinii Leach, 1817 novo registro de Brachyura (Decapoda, Leucosiidae) para o litoral de Santa Catarina. Nauplius, 7: 193-195.

Robles, R.; Schubart, C.D.; Conde, J.; Carmona-Suárez, C.; Alvarez, F.; Villalobos, J.\& D.L. Felder. 2007. Molecular phylogeny of the American Callinectes Stimpson, 1860 (Brachyura: Portunidae) based on two partial mitochondrial genes. Marine Biology, 150: 1265-1274.

Rodrigues da Costa, H. 1968. Crustacea Brachyura récoltés par les dragages de la "Calypso" sur les cotes brésiliennes. Bulletin Rec. Trav. St. Mar. End, 43(59): 333-342.

Rodríguez de la Cruz, M.C. 1987. Crustáceos decápodos del Golfo de California. México. Secretaria de Pesca, 306pp.

Rodriguez, G. 1980. Crustaceos Decapodos de Venezuela. Caracas: Instituto Venezolano de Ivestigaciones Cientificas, 494pp.

Rossi, N. 2012. Revisão das espécies de Macrobrachium olfersii (Crustacea, Palaemonidae); análises morfológicas e moleculares. Faculdade de Filosofia Ciências e Letras de Ribeirão Preto, Universidade de São Paulo, Ribeirão Preto, 135pp. Dissertação de mestado.

Rouse, W.L. 1970. Littoral Crustacea from southwest Florida. Quarterly Journal of the Florida Academy of Science, $\underline{32(2): 127-152 .}$

Russo, C.A.M.; Miyaki, C.Y. \& S.L. Pereira. 2001. Reconstrução Filogenética: Métodos Geométricos. In: Matioli, S.R. (Ed). Biologia Molecular e Evolução. Holos Editora. 108-116pp. 
Saint Laurent, M. de. 1980. Sur la classification et la phylogénie des Crustacés Décapodes Brachyoures. I. Podotremata Guinot, 1977 et Eubrachyura sect. nov. Comptes Rendus Hebdomadaires des Séances de l'Académie des Sciences, 290: 1265-1268.

Sakai, T. 1976. Crabs of Japan and the Adjacent Seas. Tokyo: Kodansha Ltd, 773 pp.

Samouelle, G. 1819. The entomologist's useful compendium; or an introduction to the knowledge of British insects, comprising the best means of obtaining and preserving them, and a description of the apparatus generally used; together with the genera of Linné, and the modern method of arranging the classes Crustacea, Myriapoda, Spiders, Mites and Insects, from their affinities and structure, according to the views of Dr. Leach. Also an explanation of the terms used in entomology; a calendar of the times of appearance and usual situations of near 3,000 species of British insects; with instructions for collecting and fitting up objects for the microscope. London, $496 \mathrm{pp}$.

Schneider, H. 2007. Método de Análise Filogenética. 3ª̣ed. Ribeirão Preto. Holos Editora e Sociedade Brasileira de Genética, 200pp.

Schubart, C.D. \& M.G.J. Huber. 2006. Genetic comparisons of German populations of the stone crayfish, Austropotamobius torrentium (Crustacea: Astacidae). Bulletin Français de la Pêche et de la Pisciculture, $\underline{380}$-381: 1019-1028.

Schubart, C.D.; Neigel, J.E. \& D.L. Felder. 2000. Use of the mitochondrial $16 S$ rRNA gene for phylogenetic and population studies of Crustacea. Crustacean Issues, 12: $817-830$.

Severino-Rodrigues, E.; Guerra, D.S.F. \& R. Graça-Lopes. 2002. Carcinofauna acompanhante da pesca dirigida ao camarão setebarbas (Xiphopenaeus kroyeri) desembarcada na praia do Perequê, Estado de São Paulo, Brasil. Boletim do Instituto da Pesca, 28 (1): 33-48.

Silva, J.M.; Creer, S.; Santos, A.; Costa, A.C.; Cunha, M.R.; Costa, F.O. \& G.R. Carvalho. 2011. Systematic and Evolutionary Insights Derived from mtDNA COI Barcode Diversity in the Decapoda (Crustacea: Malacostraca). Plos One, 6(5): 1-15.

Sosa Hernández, P.; Hernández Aguilera, J.L. \& J.L. Villalobos-Hiriart. 1980. Estudio prospective de los crustáceos (Decapoda y Stomatopoda) del Golfo de 
Tehuantepec, México. Secretaría de Marina, Dirección General de Oceanografía. Inv. Ocean., $\underline{80-10}$ : 1-50.

Souza, J.A.F. 1997. Brachyura da plataforma meridional do Rio Grande do Sul, Brasil (Crustácea, Decapoda). Nauplius, $\underline{5}(2): 33-58$.

Spivak, E. 1997. Los crustáceos decápodos del Atlántico sudoccidental (25ํ-55오): distribución y ciclos de vida. Investigaciones Marinas, 25: 69-91.

Stamatakis, A. 2006. RAxML-VI-HPC: Maximum likelihood-based phylogenetic analyses with thousands of taxa and mixed models. Bioinformatics, 22: 26882690.

Stevcic, Z. 1973. The Systematic Position of the Family Raninidae. Sistematic Biology, 22(4): 625-632

Stimpson, W. 1857. Prodromus descriptionis animalium evertebratorum in expeditione ad Oceanum Pacificum Septentrionalem missa, C. Ringgold et Johanne Rodgers ducibus, observatorum et descriptorum. Pars III. Crustacea Maioidea. Proceedings of the Academy of Natural Sciences of Philadelphia, 9: 216-221.

Stimpson, W. 1859. Notes on North America Crustacea I. Annals of the Lyceum of Natural History of New York, ㅁ: 49-93.

Stimpson, W. 1871. Notes on North American Crustacea in the Museum of the Smithsonian Institution. No. III. Annals of the Lyceum of Natural History of New York, 10: 92-136.

Stimpson, W. 1907. Report on the Crustacea (Brachyura and Anomura) collected by the North Pacific Exploring Expedition, 1853-1856. Smithsonian Miscellaneous Collections, $\underline{49}:$ 1-240.

Swofford, D.L. 2003. PAUP. Phylogenetic Analysis Using Parsimony (and other methods). Version 4.0b.10. Sunderland: Sinauer Associates.

Tabb, D.C. \& R.B. Manning. 1961. A checklist of the flora and fauna of northern Florida Bay and adjacent brackish waters of the Florida mainland collected during the period July, 1957 through September, 1960. Bulletin of Marine Science of the Gulf and Caribbean, 11: 552-649. 
Taissoun, N.E. 1986-88. Los cangrejos decapodos Brachyura de las costas da Venezuela. III. Familias Leucosiidae Dana, 1852 y Geryonidae (Beurlen, 1930). Bol. Cont. Invest. Biol., 17: 121-140.

Takeda, M. 1983. Crustaceans. In: Takeda, M. \& T. Okutani. Crustaceans and Mollusks Trawled Off Suriname and French Guiana. Tokyo: Japan Marine Fishery Resource Research Center, 185pp.

Tamura, K. \& M. Nei. 1993. Estimation of the number of nucleotide substitutions in the control region of mitochondrial DNA in humans and chimpanzees. Molecular Biology and Evolution. 10(3): 512-526.

Taylor, A.C. 1984. Branchial ventilation in the burrowing crab, Atelecyclus rotundatus. Journal of the Marine Biological Association of the United Kingdom, 64: 7-20.

Teixeira, G.M. 2010. Dinâmica populacional de caranguejos marinhos (Crustacea, Decapoda, Brachyura) do sudeste do Brasil. Universidade Estadual Paulista “Julio de Mesquita Filho", Botucatu, 86pp. Tese de doutorado.

Thompson, J.D.; Higgins, D.G. \& T.J. Gibson. 1994. Clustal W, improving position the sensitivity of progressive multiple sequence alignment through sequence weighting, position specific, gap penalties and weight matrix choice. Nucleic Acid Research, 22(22): 4673-4680.

Toon, A.; Finley, M.; Staples, J. \& K.A. Crandall. 2009. Decapod phylogenetics and molecular evolution. In: Martin, J.W.; Crandall, K.A. \& D.L. Felder (eds.). Decapod Crustacean Phylogenetics. Crustacean Issues. Koenemann, S. (series ed.) Vol. 18. Boca Raton, London, New York: CRC Press, Taylor \& Francis Group, 15-29.

Torres, M.F.A. 1998. Taxonomia e Biogeografia das Espécies da Família Leucosiidae (Crastacea: Decapoda: Brachyura) no Litoral Brasileiro. Instituto Oceanográfico da Universidade de São Paulo, São Paulo, 232pp. Tese de doutorado.

Varón, A.; Vinh, L.S. \& W.C. Wheeler. 2010. POY version 4: phylogenetic analysis using dynamic homologies. Cladistic, $\underline{26}$ (1): 72-85.

Vergamini, F.G. 2009. Análise Comparativa Entre Populações Costeiras e Continentais do Camarão Macrobrachium (Heller, 1862) (Crustacea, Palaemonidae) por Meio de Dados Morfológicos e Moleculares. Faculdade de 
Filosofia Ciências e Letras de Ribeirão Preto, Universidade de São Paulo, Ribeirão Preto, 101pp. Dissertação de mestado.

Vergamini, F.G.; Pileggi, L.G. \& F.L. Mantelatto. 2011. Genetic variability of the Amazon River prawn Macrobrachium amazonicum (Decapoda, Caridea, Palaemonidae). Contributions to Zoology, 80(1): 67-83.

Vieira, R.R.R. \& D.K. Calazans. 2010. Chave ilustrada para identificação das zoés de Brachyura do estuário da Lagoa dos Patos (RS) e região costeira adjacente. Biota Neotropical, 10(3): 431-437.

Walker, G. 1974. The occurrence, distribution and attachment of the pedunculate barnacle Octolasmis mülleri (Coker) on the gills of crabs, particularly the blue crab, Callinectes sapidus Rathbun. Biology Bulletim, 147: 678-689.

Wass, M.L. 1955. The decapod crustaceans of Alligator Harb or and adjacent inshore areas of northwestern Florida. Quarterly Journal of the Florida Academy of Sciences, 18: 129-176.

Wehrtmann, I.S. \& S. Echeverría-Sáenz. 2007. Crustacean fauna (Stomatopoda: Decapoda) associated with the deepwater fishery of Heterocarpus vicarius (Decapoda: Pealidae) along the Pacific coast of Costa Rica. Revista de Biología Tropical, 55(1): 121-130.

Wells, H.W. \& M.J. Wells 1961. Observations on Pinnaxodes floridensis, a new species of pinnotherid crustacean commensal in holothurians. Bulletin of Marine Science of the Gulf and Caribbean, 11(2): 267-279.

Werding, B. \& H.G. Müller. 1989. Leucosiidae von der Nordküste Kolumbiens (Crustacea: Decapoda: Brachyura). Senckenbergiana Biologica, 70(4/6): 405-417.

Wheeler, W.C. 1996. Optimization alignment: the end of multiple sequence alignment in phylogenetics? Cladistics, 12: 1-9.

Wicksten, M.K. \& J.M. Packard. 2005. A qualitative zoogeographic analysis of decapod crustaceans of the continental slopes and abyssal plain of the Gulf of Mexico. Deep Sea Research I, 52: 1745-1765.

Williams, A.B., 1965. Marine decapod crustaceans of the Carolinas. Fishery Bulletin, 65(1): 1-298. 
Williams, A.B. 1974. Marine flora and fauna of the northeastern United States, Crusatacea: Decapoda. National Oceanic and Atmospheric Administration Technical Report, National Marine Fisheries Service Circular, 389: 1-50.

Williams, A.B. 1984. Shrimps, Lobsters and Crabs of the Atlantic Coast of the Eastern United States. Smithsonian Institution Press, Washington, United States, 550pp. Witzell, W.N. \& J.R. Schmid. 2005. Diet of immature kemp's ridley turtles (Lepidochelys kempi) from Gullivan Bay, ten thousand islands, Southwest Florida. Bulletin of Marine Science, 77(2): 191-199.

Xia, X. \& Z. Xie. 2001. DAMBE: Software package for data analysis in molecular biology and evolution. Journal of Heredity, 92: 371-373.

Xia, X. \& P. Lemey. 2009. Assessing substitution saturation with DAMBE. In: Lemey, P.; Salemi, M.; \& A. Vandamme (eds). The Phylogenetic Handbook: A Pratical Approach to DNA and Protein Phylogeny. $2^{\text {nd }}$ edition. Cambridge University Press. Pp. 615-630.

Young, A.M.; Torres, C.; Mack, J.E. \& C.W. Cunningham. 2002. Morphological and genetic evidence for vicariance and refugium in Atlantic and Gulf of Mexico populations of the hermit crab Pagurus longicarpus. Marine Biology, 140: 10591066. 